\title{
PEPPER : persistent ear problems, providing evidence for referral
}

Citation for published version (APA):

Lok, W. (2012). PEPPER : persistent ear problems, providing evidence for referral. [Doctoral Thesis, Maastricht University]. Maastricht University. https://doi.org/10.26481/dis.20120309wl

Document status and date:

Published: 01/01/2012

DOI:

10.26481/dis.20120309wl

Document Version:

Publisher's PDF, also known as Version of record

\section{Please check the document version of this publication:}

- A submitted manuscript is the version of the article upon submission and before peer-review. There can be important differences between the submitted version and the official published version of record.

People interested in the research are advised to contact the author for the final version of the publication, or visit the DOI to the publisher's website.

- The final author version and the galley proof are versions of the publication after peer review.

- The final published version features the final layout of the paper including the volume, issue and page numbers.

Link to publication

\footnotetext{
General rights rights.

- You may freely distribute the URL identifying the publication in the public portal. please follow below link for the End User Agreement:

www.umlib.nl/taverne-license

Take down policy

If you believe that this document breaches copyright please contact us at:

repository@maastrichtuniversity.nl

providing details and we will investigate your claim.
}

Copyright and moral rights for the publications made accessible in the public portal are retained by the authors and/or other copyright owners and it is a condition of accessing publications that users recognise and abide by the legal requirements associated with these

- Users may download and print one copy of any publication from the public portal for the purpose of private study or research.

- You may not further distribute the material or use it for any profit-making activity or commercial gain

If the publication is distributed under the terms of Article $25 \mathrm{fa}$ of the Dutch Copyright Act, indicated by the "Taverne" license above, 

Het drukken van het proefschrift werd mede mogelijk gemaakt door:

De nationale hoorstichting/Vriendenloterij; ALK-Abelló; Atos Medical BV;

Dosmedical; Schooneberg hoorcomfort; Stallergenes

ISBN: 978-94-6191-184-1

Copyright $@ 2012$ W. Lok

Niets uit deze uitgave mag worden verveelvoudigd, opgeslagen in een geautomatiseerd gegevensbestand of openbaar gemaakt worden in enige vorm of op enige wijze, hetzij elektronisch, mechanisch of door fotokopieën, opname, of op enige andere manier, zonder voorafgaande schriftelijke toestemming van de auteur. 


\title{
PEPPER
}

Persistent Ear Problems, Providing Evidence for Referral

\author{
Willeke Lok
}





\section{PEPPER}

\section{Persistent Ear Problems, Providing Evidence for Referral}

\section{Proefschrift}

ter verkrijging van de graad van doctor aan de Universiteit Maastricht op gezag van de rector magnificus

Prof. mr. G.P.M.F. Mols

en volgens het besluit van het College van

Dekanen

in het openbaar te verdedigen op

vrijdag 9 maart 2012 om 14.00 uur

door

Willemke Lok

geboren te Assen 


\section{Promotoren}

Prof. dr. B. Kremer

Prof. dr. M.P. Haggard (University of Cambridge, United Kingdom)

\section{Co-promotor}

Dr. L.J.C. Anteunis

\section{Beoordelingscommissie}

Prof. dr. R.J. Stokroos (voorzitter)

Prof. dr. G.J. Dinant

Dr. J.A.M. Engel (Canisius-Wilhelmina ziekenhuis te Nijmegen)

Prof. dr. F.J.M. Feron

Prof. dr. A.G.M. Schilder (Universiteit Utrecht) 
Twenty years from now you will be more disappointed by the things you did not do, than by the things you did do. So throw off the bowlines. Sail away from the safe harbour. Catch the trade winds in your sails. Explore. Dream. Discover.....

Mark Twain 



\section{CONTENTS}

CHAPTER 1 General introduction 3

CHAPTER 2 Implementation of neonatal screening for hearing 13 impairment: Influence on paediatric otitis media surgery in The Netherlands

CHAPTER 3 Screening for hearing loss versus parental concern because of ear and/or hearing problems and subsequent referral and treatment for otitis media in the Netherlands

CHAPTER 4 Referral and treatment for otitis media in the

Netherlands before and after the disappearance of the hearing screen at age nine months

CHAPTER 5 Risk factors for failing the hearing screen due to otitis media in Dutch infants

CHAPTER 6 Selecting infants with OM that need referral and further assessment: creating a case-finding instrument

CHAPTER 7 Discussion

CHAPTER 8 Summary and Conclusion

Dankwoord

Curriculum Vitae 



\section{GENERAL INTRODUCTION}

\section{PEPPER}

Persistent Ear Problems, Providing Evidence for Referral 
Otitis media $(\mathrm{OM})$ is very common in young children ${ }^{1-4}$. Around $65 \%$ of all children will have developed at least one episode of OM by age 6 months and around $80 \%$ of all children at age 1 year ${ }^{1,5}$. More than $90 \%$ of all the two-year-olds will have had at least one episode of $\mathrm{OM}^{1,4}$.

As OM usually resolves spontaneously within a limited period of time, many children will have a (relatively) short lasting problem and treatment will not be necessary ${ }^{6}$. However hearing loss is a distinct risk of OM. When persisting for a longer period of time this hearing loss can cause speech and language problems. OM can also cause behavioural problems ${ }^{7}$, balance problems ${ }^{8}$ and, less specifically, affect the quality of life of the children ${ }^{9,10}$. Treatment of the OM-related hearing loss can improve hearing ${ }^{6}$, speech development ${ }^{11}$ and quality of life ${ }^{10}$. Effective detection and subsequent treatment of OM-related hearing loss is therefore necessary.

When diagnosing OM, one should differentiate between acute otitis media $(\mathrm{AOM})$ and otitis media with effusion (OME). Both AOM and OME can be seen as different stages of an OM continuum ${ }^{12}$. However, AOM is very symptomatic with fever, ear pain and otorrhoe. OME on the other hand is a condition where there is fluid in the middle ear without signs of an acute infection. Therefore OME is less symptomatic than AOM. OME can occur as a primary disorder, but also occurs as a sequel to AOM or accompany upper respiratory tract infections such as common colds. OME occurring after an episode of AOM will, in $74 \%$ of all children, resolve within 3 months ${ }^{1}$. The effusions are more persistent when the onset is unknown and in $58 \%$ of all children these effusions persist at least 6 months ${ }^{13}$.

OM, i.e. fluid in the middle ear, can cause hearing loss which can be variable in severity. It can range between $0-50 \mathrm{~dB}^{14}$, although in unselected populations usually the hearing loss is mild, ranging around 5-6 dB ${ }^{15}$. Speech and language problems can occur when there is a significant hearing loss $\left(20-30 \mathrm{~dB}^{16}\right)$ persisting for a longer period of time ${ }^{17}$. Hearing loss is therefore a distinct risk of $\mathrm{OM}$.

Detection of OM-related hearing loss in young children can be difficult for their parents. Especially when the child has OME without any episodes of 
AOM or when the child is still very young ${ }^{18,19}$ detection of hearing loss by the parents is unreliable.

In the Netherlands, until 2006, all children were screened for hearing loss at the age of nine months at the well baby clinic by means of the distraction hearing test ${ }^{20,21}$. If children would fail the first test, they were screened a second time one month later, and again one month later after failing the second test. Usually a child would be tested a maximum of three times within a two to three months period. Children were referred to their general practitioner (GP) upon either failing the CAPAS three times or failing twice combined with other problems warranting referral, for example developmental problems, or a suspected severe hearing loss.

The screen was originally introduced to detect children with congenital and/or early acquired sensorineural and permanent conductive hearing loss, but most children failed the screen because of OM-related hearing loss ${ }^{22-24}$. The screen therefore functioned as a tool to detect otherwise healthy infants without obvious signs or symptoms with OM-related hearing loss.

The Dutch guidelines for GPs ${ }^{25}$ advised to watchful wait and observe these children whenever there was OM present without accompanying problems. If there were problems accompanying the $\mathrm{OM}$ or if the effusions persisted for more than 3 months, referral to an audiology centre or to an Ear, Nose and Throat (ENT) department was advised. At the ENT department the children with OM were further examined and often surgical treatment of OM followed.

Treatment for OM depends on accompanying symptoms and signs. When a child has repeated AOM episodes or when there is OM-related hearing loss, treatment with ventilation tubes can resolve the problem ${ }^{26,27}$. Clearing the fluid from the middle ear will restore hearing ${ }^{26}$ and is also the presumed route in solving balance problems in children with $\mathrm{OME}^{8}$. Sometimes the child has also upper respiratory tract infections and an adenoidectomy or adenotonsillectomy or a combination of one of these two with tubes is judged necessary ${ }^{12,25}$.

From 2002-2006 the hearing screen at nine months was gradually replaced by the neonatal hearing screen, conducted in the first weeks after birth. A 
unilateral or bilateral fail will lead to a second screen. When the child fails the third screen, he/she will be referred to the audiology centre. The first two screens use transient evoked oto-acoustic emissions, the third screen uses automated auditory brainstem responses.

The neonatal screen enables the detection of congenital and/or early acquired sensorineural and permanent conductive hearing loss at a much younger age. When hearing loss is detected at a younger age, treatment can be started earlier, thus preventing developmental delays in speech and language. Therefore the neonatal screen is associated with better developmental outcomes for those children with permanent childhood hearing impairment ${ }^{28}$. However, children developing a significant OM-related hearing loss, previously found with the hearing screen at nine months, will probably no longer be detected. This could be a problem for their speech and language development.

Returning to the hearing screen at age nine months just to detect OM-related hearing loss is not a solution. We now know that screening for hearing loss in a general population of asymptomatic children and subsequent treatment with tubes is not effective ${ }^{16}$. Too many children with a transient and/or relatively mild hearing loss failed the screen and were treated for OM. However, OM is a common problem with a high spontaneous recovery, suggesting it to be a natural phenomenon ${ }^{12}$. Only a subgroup of children has more persistent $\mathrm{OM}$ and OM-related hearing loss and need further assessment and possibly treatment.

Many researchers have attempted to identify risk factors associated with OM in an attempt to single out the children that need attention. There are however no studies specifically addressing risk factors for persistent significant OM-related hearing loss. Therefore it remains difficult to detect these children. An instrument for selecting those children with OM that need further assessment and possibly treatment does not yet exist.

Mary Gannon and Mark Haggard started with the development of an instrument for selecting children with OM that need further assessment. They designed the original PEPPER study ('Persistent Ear Problems, Providing Evidence for Referral') in the United Kingdom. Findings from the 
TARGET (the UK national Trial of Alternative Regimes in Glue Ear Treatment) database showed that there were indeed benefits from surgical treatment of OM, but only if appropriate criteria had been applied at the selection stage. There was an apparent need of a tool that could help in selecting those children visiting the GP that could benefit from referral and potentially from surgery. The PEPPER item pool embraces a wide range of OM-related factors combined in a single instrument for use in primary care. The PEPPER study in the UK did not lead to any publications.

\section{AIMS AND OUTLINE OF THIS THESIS}

In this thesis we aim to develop a case-finding instrument for identifying those infants with diagnosed or suspected OM-related hearing loss who are at risk for developmental problems. Identification of these infants enables treatment to prevent any developmental problems. Not only would these infants benefit from such a tool. A truly effective case-finding instrument also contributes to a more effective care system in which referral for further (surgical) treatment is given only to those infants that can benefit from it. In our research we started by substantiating the need for a case finding instrument. Next we used and analysed known and presumed risk factor items for OM, OM-related hearing loss and OM treatment. Finally we made use of the PEPPER item pool, to find a combination of risk factor items that could function as a case-finding instrument. These steps resulted in the creation of five study questions:

1. Did the disappearance of the hearing screen at nine months have an impact on the number of children surgically treated for OM? (Chapter 2)

2. What was the referral pathway of the children with ear/hearing problems when the hearing screen at nine months was still present? (Chapter 3)

3. How did children that passed the neonatal hearing screen but developed ear and/or hearing problems later on, find their way to the ENT department compared to the period when the hearing screen at nine months was still present? (Chapter 4)

4. Which items of the PEPPER item pool have increased odds for referral after the hearing screen? (Chapter 5). 
5. What combinations of items from the PEPPER item pool best predict treatment with tubes? (Chapter 6)

In the next section a brief overview is given of the design of the studies that were necessary to answer the questions mentioned above and to develop a case-finding instrument. The next chapters will focus on each individual study question in detail.

\section{STUDY DESIGN AND METHODS}

To analyse the effect of the disappearance of the hearing screen on the number of children surgically treated for OM externally available data was used. More specifically national birth rates (Centraal Bureau voor de Statistiek), data regarding screening for hearing impairment at the age of nine months and at the neonatal period (Nederlandse Stichting voor het Dove en Slechthorende Kind) and finally data regarding adenoidectomy and tube placement (Prismant) was used. With these data the treatment of otitis media in children aged 0-2 years in the Netherlands for the years 1995-2007 was studied. The results are presented in Chapter 2.

\section{Questionnaires}

To study the referral pathway and identify any risk factors for OM-related hearing loss in otherwise healthy infants, three questionnaires were selected and created.

\section{PEPPER item pool and PEPPER questionnaire}

The PEPPER item pool, developed in the UK by M. Gannon and M. Haggard, embraces a wide range of OM-related factors in a single instrument for use in primary care and can be completed by the child's parents or guardians within 3 minutes. To facilitate use, the items were pooled into the PEPPER questionnaire (Appendix A).

\section{Retrospective questionnaire: Q21}

To be able to obtain a structured history, a questionnaire regarding the first 21 months of the child was created. This questionnaire consists of 12 questions regarding attending the hearing screen, referral subsequent to this hearing screen, visits to the GP because of ear and/or hearing problems and 
subsequent referral to a specialist (ENT specialist, paediatrician, audiology centre, etc.) and treatment by an ENT specialist (Appendix B).

\section{Combined questionnaire: Q30}

As we were interested in referral and treatment because of ear and/or hearing problems before and after the implementation of the neonatal hearing screen, i.e. replacement of the CAPAS at age nine months, we created a third questionnaire, called Q30. The Q30 consists of a combination of the questions of the PEPPER questionnaire and the Q21 questionnaire in one questionnaire. Therefore we had a structured history questionnaire together with risk factor items for OM (Appendix A+B).

\section{Study populations}

In this study the questionnaires were send to two study populations:

\section{Study population 1}

The PEPPER questionnaire was send to all children, born between 1-6-2004 and 31-12-2004 in the province of Limburg, the Netherlands, and who were invited for the CAPAS at age nine months. At age 21 months, parents of all children who had returned the first questionnaire received the Q21 questionnaire.

\section{Study population 2}

The questionnaire Q30 was send to children aged 21-33 months in September 2010. These children were therefore born between 1-12-2007 and 30-11-2008 and living in the province of Limburg, the Netherlands.

\section{Exclusion criteria}

Infants with a permanent conductive or a sensorineural hearing loss, children with Down syndrome, children with cleft syndrome and children with other craniofacial malformation were excluded.

\section{Outcome measures}

In the analysis of the questionnaires referral was taken as marking persistent OM-related hearing loss. Referral meant: failing the CAPAS three times or two times with accompanying problems, where after referral.

A second outcome measure, treatment with ventilation tubes, was used to analyse ear and/or hearing problems warranting surgical treatment. We only 
studied surgical treatment with ventilation tubes because we know that the children treated with tubes are children with OM. We did not use adenoidectomy and/or adenotonsillectomy as outcome measure because these surgical procedures are used for upper respiratory tract infections in general and not specific for OM.

\section{Analysis}

By analysing the results from the questionnaires, the remaining four study questions could be answered. The Q21 questionnaire covers the history between birth and 21 months of age and was sent to children who were invited for the hearing screen at the age of nine months. It was used to obtain information on referral after failing the hearing screen, GP consultations with ear/hearing problems, and subsequent referral to a specialist and possible surgical treatment at an ENT department. This information is described in Chapter 3.

The Q30 questionnaire was used to obtain information on children for whom the hearing screen at nine months was replaced by the neonatal hearing screen. Information of any visits to general practitioners and ENT specialists and subsequent treatment for ear and/or hearing problems was analysed. In Chapter 4 a comparison is made with data from the period when the hearing screen at nine months was still present.

Chapter 5 presents the results of the analysis which items of the PEPPER item pool had increased the odds for referral after failing the hearing screen. The PEPPER questionnaire and the results of the hearing screen at age nine months were used for this analysis.

Finally the PEPPER questionnaire and the Q21 questionnaire were used to analyse which combination of items from the PEPPER questionnaire best predicted the outcome 'treatment with tubes'. The result are described in Chapter 6 and the developed scoring sheet, i.e. the case-finding instrument, is also described in this chapter.

In Chapter 7 this thesis ends with a short 'Discussion'. Although we have presented a scoring sheet in Chapter 6, further 'fine-tuning' is necessary. Some hints are given for further study and development. Hopefully we can implement an effective case-finding instrument in the Netherlands in the nearby future. 


\section{REFERENCES}

1. Paradise JL, Rockette HE, Colborn DK et al. Otitis media in 2253 Pittsburgharea infants: prevalence and risk factors during the first two years of life. Pediatrics 1997;99:318-333.

2. Alho OP, Oja H, Koivu M, Sorri M. Chronic otitis media with effusion in infancy. How frequent is it? How does it develop? Arch Otolaryngol Head Neck Surg 1995;121:432-436.

3. Zielhuis GA, Rach GH, Van den Broek P. The occurrence of otitis media with effusion in Dutch pre-school children. Clin Otolaryngol Allied Sci 1990;15:147-153.

4. Casselbrant ML, Brostoff LM, Cantekin EI et al. Otitis media with effusion in preschool children. Laryngoscope 1985;95:428-436.

5. Marchant CD, Shurin PA, Turczyk VA, Wasikowski DE, Tutihasi MA, Kinney SE. Course and outcome of otitis media in early infancy: a prospective study. J Pediatr 1984;104:826-831.

6. Lous J, Burton MJ, Felding JU, Ovesen T, Rovers MM, Williamson I. Grommets (ventilation tubes) for hearing loss associated with otitis media with effusion in children. Cochrane Database Syst Rev 2005:CD001801.

7. Bennett KE, Haggard MP, Silva PA, Stewart IA. Behaviour and developmental effects of otitis media with effusion into the teens. Arch Dis Child 2001;85:91-95.

8. Casselbrant ML, Villardo RJ, Mandel EM. Balance and otitis media with effusion. Int J Audiol 2008;47:584-589.

9. Lee J, Witsell DL, Dolor RJ, Stinnett S, Hannley M. Quality of life of patients with otitis media and caregivers: a multicentre study. Laryngoscope 2006;116:1798-1804.

10. Richards M, Giannoni C. Quality-of-life outcomes after surgical intervention for otitis media. Arch Otolaryngol Head Neck Surg 2002;128:776-782.

11. Rovers MM, Straatman H, Ingels K, van der Wilt GJ, van den Broek P, Zielhuis GA. The effect of ventilation tubes on language development in infants with otitis media with effusion: A randomized trial. Pediatrics 2000;106:E42.

12. Rovers MM, Schilder AG, Zielhuis GA, Rosenfeld RM. Otitis media. Lancet 2004;363:465-473.

13. Rosenfeld RM, Kay D. Natural history of untreated otitis media. Laryngoscope 2003;113:1645-1657.

14. Fria TJ, Cantekin EI, Eichler JA. Hearing acuity of children with otitis media with effusion. Arch Otolaryngol 1985;111:10-16.

15. Anteunis LJC, Engel JAM, Hendriks JJT, Volovics A, Chenault MN, Manni JJ. Otitis media with effusion algorithms and the associated hearing loss in infants 0-2. In Anteunis LJC and Engel JAM, Maastricht Otitis Media with Effusion Study. A prospective study in infants from 0 to 2 years. PhD thesis. Department of Otorhinolaryngology and Head and Neck Surgery and the Maastricht Brain and Behavior Institute. Maastricht: University of Maastricht, 2000:141-154. 
16. Butler CC, van der Linden MK, MacMillan H, van der Wouden JC. Screening children in the first four years of life to undergo early treatment for otitis media with effusion. Cochrane Database Syst Rev 2003:CD004163.

17. Teele DW, Klein JO, Chase C, Menyuk P, Rosner BA. Otitis media in infancy and intellectual ability, school achievement, speech, and language at age 7 years. Greater Boston Otitis Media Study Group. J Infect Dis 1990;162:685694.

18. Anteunis LJ, Engel JA, Hendriks JJ, Manni JJ. A longitudinal study of the validity of parental reporting in the detection of otitis media and related hearing impairment in infancy. Audiology 1999;38:75-82.

19. Rosenfeld RM, Goldsmith AJ, Madell JR. How accurate is parent rating of hearing for children with otitis media? Arch Otolaryngol Head Neck Surg 1998;124:989-992.

20. van Leerdam FJ. [Youth Health Care Services guideline 'Early screening for hearing impairment, 0-19 years']. Ned Tijdschr Geneeskd 2000;144:598-601.

21. Leerdam FJMvr. JGZ-standaard vroegtijdige opsporing van gehoorstoornissen 0-19 jaar. Bohn Stafleu Van Loghum Houten 1998.

22. Rovers MM, Zielhuis GA, Straatman H, Ingels K, van der Wilt GJ, Kauffmande Boer M. Comparison of the CAPAS and Ewing tests for screening of hearing in infants. J Med Screen 1999;6:188-192.

23. Mott A, Emond A. What is the role of the distraction test of hearing? Arch Dis Child 1994;70:10-13.

24. Rovers MM, Straatman H, Zielhuis GA, Ingels K, van der Wilt GJ. Seasonal variation in the prevalence of persistent otitis media with effusion in one-yearold infants. Paediatr Perinat Epidemiol 2000;14:268-274.

25. Boomsma LJ, Rovers MM, van Balen FA, Wiersma T, Goudswaard AN. [The practice guideline 'Otitis media with effusion' (second revision) from the Dutch College of General Practitioners]. Ned Tijdschr Geneeskd 2007;151:267-268; author reply 268.

26. Browning GG, Rovers MM, Williamson I, Lous J, Burton MJ. Grommets (ventilation tubes) for hearing loss associated with otitis media with effusion in children. Cochrane Database Syst Rev 2010:CD001801.

27. McDonald S, Langton Hewer CD, Nunez DA. Grommets (ventilation tubes) for recurrent acute otitis media in children. Cochrane Database Syst Rev 2008:CD004741.

28. Korver AM, Konings S, Dekker FW et al. Newborn hearing screening vs later hearing screening and developmental outcomes in children with permanent childhood hearing impairment. JAMA 2010;304:1701-1708. 


\section{CHAPTER 2}

\section{Implementation of neonatal screening for hearing impairment: Influence on paediatric otitis media surgery in The Netherlands}

W. Lok, M.N. Chenault, L.J.C. Anteunis

International Journal of Pediatric Otorhinolaryngology 2009; 1090-1994 


\begin{abstract}
Objective Screening for hearing impairment in the Netherlands took place at the age of 9 months for many years but was recently moved to the neonatal period. Since otitis media has its highest prevalence at the age of 9 months, it might be that screening for hearing impairment at this age is linked to treatment of otitis media. We were interested in what the impact would be on the number of children treated with ventilation tubes or adenoidectomy when they were no longer screened at the age of nine months.
\end{abstract}

Methods National birth rates, data regarding screening for hearing impairment at the age of nine months and at the neonatal period, as well as data regarding adenoidectomy and tube placement were used to study treatment of otitis media in children aged 0-2 years in the Netherlands.

Results The percentage of children treated with ventilation tubes after implementation of neonatal screening for hearing impairment did not decline (OR $1.112-1.198$ ), and more children were treated at a younger age. The number of children treated with adenoidectomy did however decline (OR $0.724-0.890)$.

Conclusion There seems to be an association between the implementation of neonatal screening for hearing impairment and the treatment of otitis media. During the whole studied period there was a slight but statistical significant increase in the odds for tube placement in all children aged 0-23 months. After implementation of the neonatal screen there was a distinct increase in the number of children aged 6-11 months treated with tubes. In the same period a statistical significant decline in the odds of undergoing adenoidectomy was observed. 


\section{INTRODUCTION}

Otitis media (OM), a condition in which fluid accumulates in the middle ear with or without signs of acute infection, is highly prevalent in young children ${ }^{1,2}$. Surgical treatment of $\mathrm{OM}$ with ventilation tubes and/or adenoidectomy is one of the most common procedures in children in many countries. The number of surgical procedures for $\mathrm{OM}$ in the Netherlands has been relatively high for years when compared to other countries ${ }^{3}$. In the Netherlands there is a peak incidence in treatment with tubes at the age of 15 months ${ }^{4}$. This could simply be because the prevalence of OM is high at this age ${ }^{1,5,6}$. However Engel ${ }^{4}$ proposed that the high incidence of surgical treatment at this age may be due to the hearing screen at a population level at the age of 9 months. Failing this screen was most often due to hearing impairment caused by $\mathrm{OM}^{7}$. Failing this screen three times, subsequent screening occurring one month after a fail, and the subsequent referral to the general practitioner and thereafter the ENT department, as was common practice in the Netherlands, would result in children being treated for OM around the age of 15 months.

Since recent screening for hearing impairment in the Netherlands takes place at a younger age. Instead of being screened at the age of 9 months, infants are now screened in the neonatal period. We were interested in the effect this change might have on the number of infants treated with tubes and/or adenoidectomy aged 0-2 years. If surgical treatment of otitis media is linked to screening for hearing impairment at the age of nine months as Engel proposed, than the number of children treated surgically around the age of 15 months should decline after the implementation of neonatal screening.

\section{METHODS}

National birth rates during the studied period were obtained from the National Bureau of Statistics (Centraal Bureau voor de Statistiek; CBS). Population rates and absolute numbers of treatments were analyzed in order to estimate the percentage of children treated with bilateral tube insertion or adenoidectomy, taking into account the possible effect that national birth rates might have on the number of surgical procedures. 
The Dutch Society of the Deaf and Hearing Impaired Child (Nederlandse Stichting voor het Dove en Slechthorende Kind; NSDSK) made data available pertaining to attendance and measurement results of the screening for hearing impairment at age 9 months for the years 1995-2005 and the neonatal screening for hearing impairment for the years $2004-2007$. The screening at 9 months occurred by means of the distraction hearing test. In the Netherlands the Ewing as well as the CAPAS (Compact Amsterdam Paedo-Audiometrical Screening) hearing tests were used, the latter being an automated version of the Ewing. See Rovers ${ }^{7}$ for more details regarding these tests. From 2001 onward, neonatal screening using otoacoustic emissions and, after a two times fail, automated auditory brainstem response (ALGO) was gradually introduced in the Netherlands, replacing the distraction hearing test at the age of nine months. Upon introduction of this neonatal screening, some well-baby clinics no longer provided information to NSDSK about Ewing and CAPAS results after 2001.

The National Medical Registration (Prismant, www.prismant.nl) provided data regarding the numbers of treatment with bilateral tubes and adenoidectomy in the years 1995-2007, for children aged 0-23 months. These data are anonymous and publicly accessible. Due to our special interest in incidence rates of surgical treatment of infants and the possible relation there may be to hearing screening, the data is considered relative to age in months as well in years. Up to 2005 , data of all university and private hospitals in the Netherlands were linked to the National Medical Registration. In the Netherlands there are no privately practicing ENT specialists. According to the National Medical Registration the data represents $80-99 \%$ of procedures undergone in the country up to 2005 . After 2005 some hospitals chose not to register their procedures with the National Medical Registration because of the introduction of a new registration system called Diagnosis Treatment Combination (Diagnose Behandel Combinatie; DBC). The National Medical Registration did however provide information on how many hospitals were still submitting their data. We could therefore estimate the number of procedures for the years 2005-2007.

\section{Statistics}

We obtained cross tabulations and performed logistic regression modelling 
(SPSS 15.0) to analyse whether there was a change in number of procedures. The range of years 1995-1997 was taken as the reference category with the outcome variable being undergoing tube placement respectively adenoidectomy for the age groups 0-11 months and 12-23 months. Furthermore, relative percentages of tubes and adenoidectomies were investigated. National birth rates were used to estimate percentages of surgical treatment, tube placement and/or adenoidectomy in the period 19952007.

\section{RESULTS}

\section{Introduction of neonatal screening}

Neonatal screening with otoacoustic emissions and automated auditory brainstem response was introduced gradually from 2001-2004. In 2004 only $20 \%$ of all children were screened during the neonatal period. NSDSK could not provide information on 2005, but in 2006 all children were screened in the first weeks of life (Figure 1).

Figure 1. Percentage of children screened for hearing impairment with CAPAS/Ewing at 9 months, otoacoustic emissions (OAE)/automated auditory brainstem response (ALGO), or without screening or unknown, in the Netherlands for the period 2001-2004.

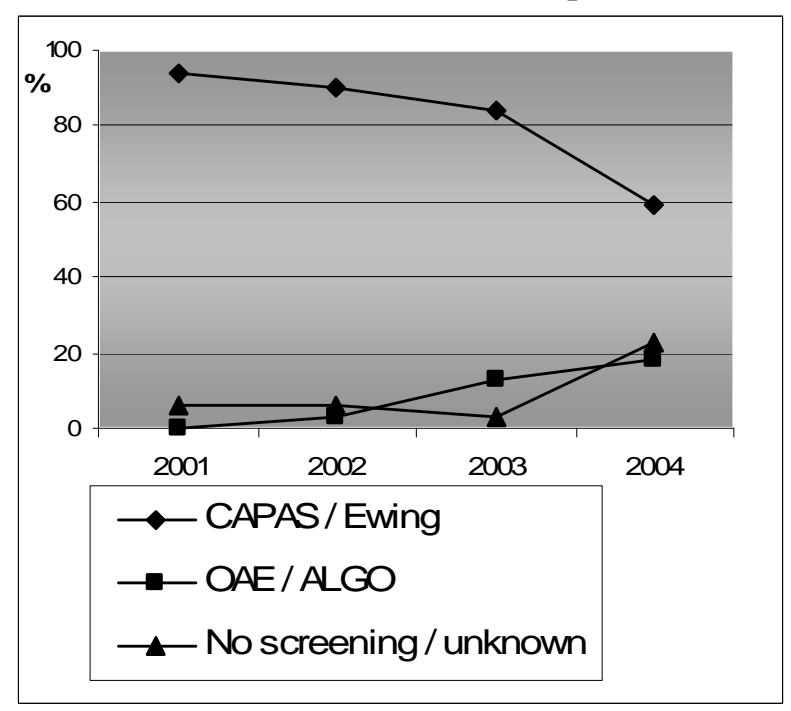




\section{National birth rates and surgical numbers}

We studied the number of children treated with tubes (Figure 2) and adenoidectomy (Figure 3) according to their age in months, to determine a possible effect of the disappearance of the hearing screen at 9 months around 2004. Until 2004, the peak incidence for both tube placement and adenoidectomy appeared to be around the age of 15 months. After 2004, the number of children treated with tubes aged 12-17 months stayed high. In the years 1995-2003 an average of 3684 children was treated with tubes every year (range 3356-4130) and the number of children treated remained constant in the following years (range 3522-4095). For children treated with adenoidectomy aged 12-17 months we found an average of 5000 cases treated for the years 1995-2003 (range 4771-5492) while there was a decrease by $15 \%$ for the years 2004-2007 (4514, 4158, 4284 and 4001, respectively) following the disappearance of the hearing screen at nine months.

Figure 2. Number of children treated with tubes analysed according to age in months from 1995-2007. The bold black line is the average number of children treated per month from 1995-2004, before the disappearance of the screening for hearing impairment at age 9 months.

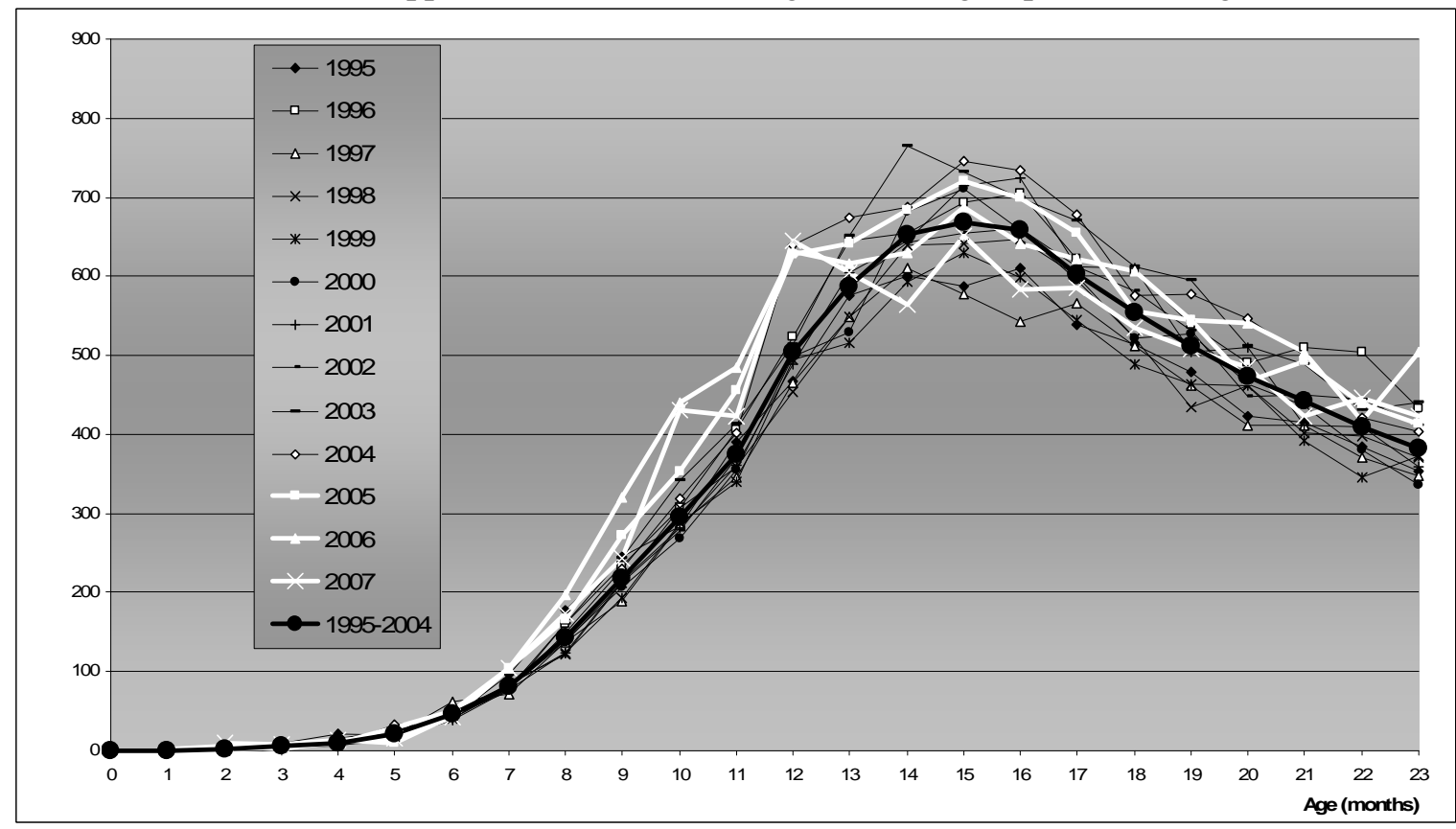


Figure 3. Number of children treated with adenoidectomy analysed according to age in months from 1995-2007. The bold black line is the average number of children treated from 1995-2004, before the disappearance of the screening for hearing impairment at age 9 months.

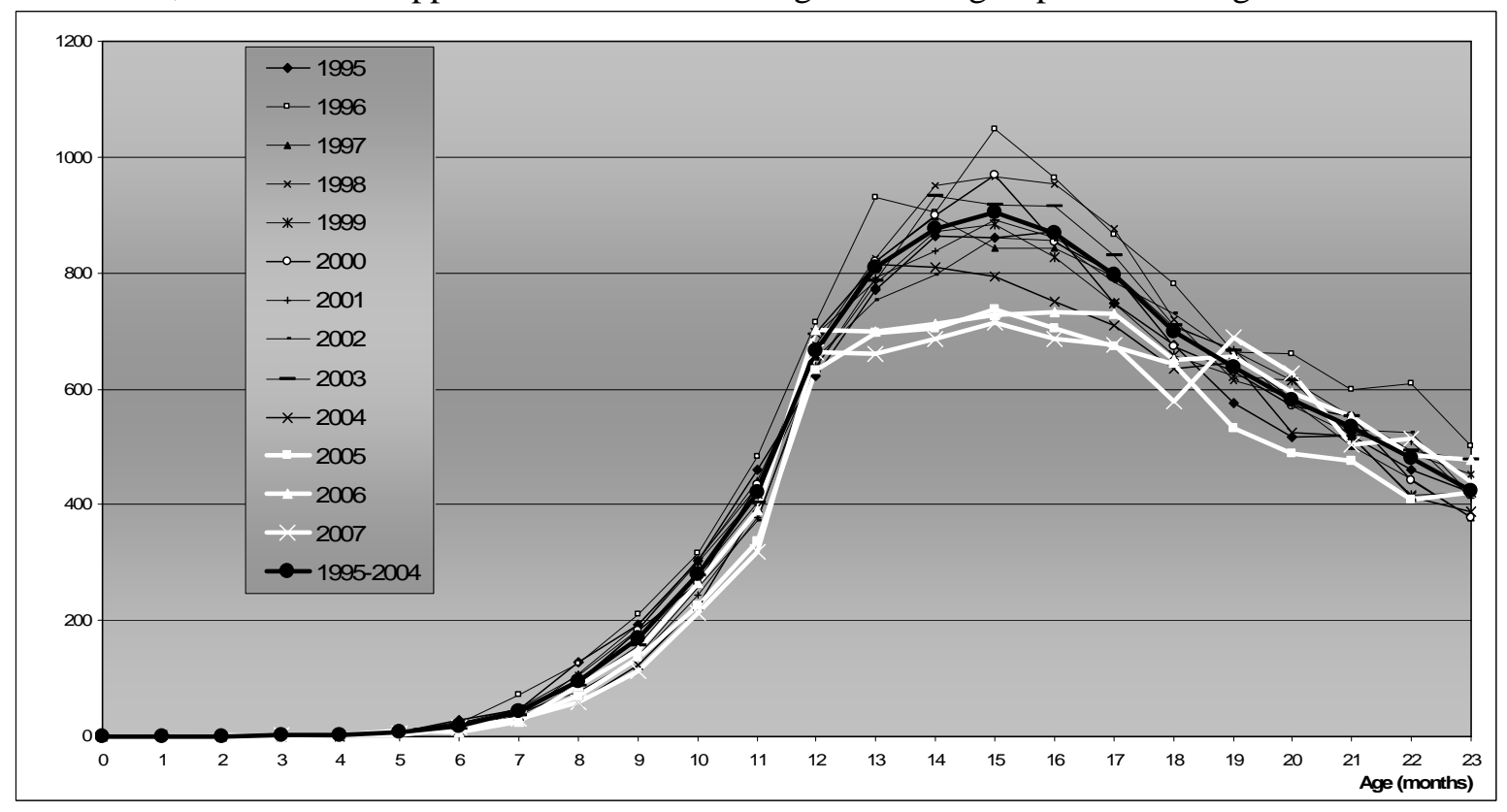

For children aged 6-11 months an increase of $25 \%$ of tube placement was seen following the disappearance of the screening at nine months, from an average of 1595 (range 1494-1749) to respectively 1816, 1980, 2180 and 2020 in the years 2004-2007. For children treated with adenoidectomy in this age group the numbers decreased from an average of 1691 (range 15221922 ) in the years $1995-2003$ to $1537,1432,1618$ and 1397 in the years 2004-2007.

In the years 1995-2007 the number of children born every year was slowly increasing from around 195000 in 1995 to 208000 in 2002, where after it slowly decreased to around 184000 in 2007.

Figure 4 shows that the percentage of children treated with tubes increased from 2000 onward. The results of logistic regression modelling are given using 1995-1997 as the reference period (Table 1). It appeared that children in the age group 0-11 months were less likely to undergo tube placement in the periods between 1998 and 2000 than in the period 1995-1997. In the period 2001-2003 the odds for tube placement were about the same 
Figure 4. Percentage of children aged 0-23 months treated with tubes or adenoidectomy compared to all children aged 0-23 months born in the Netherlands from 1995-2007.

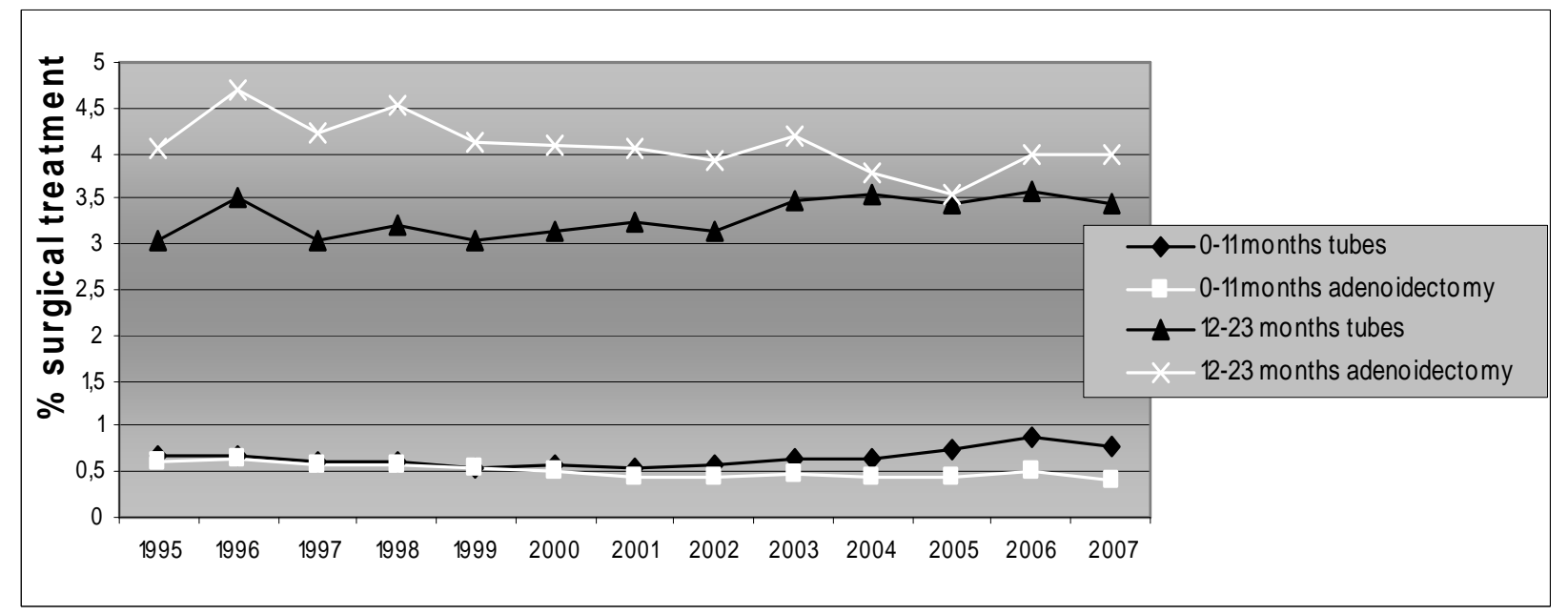

compared to the reference period. At the same time, the odds for tube placement in this age group were 1.2 in the period 2004-2007. The odd ratios of undergoing an adenoidectomy in the age group 0-11 months were statistically significant lower in the periods between 1998 and 2003, as well in the period 2004-2007 relative to the reference period 1995-1997.

As for the children in the age group from 12-23 months there is a slightly lower but statistically significant odds ratio for undergoing tube placement in the period 1998-2000 relative to the reference period but that the odds ratios

Table 1. Odds Ratios (with 95\% confidence intervals) for surgical procedures with the period 1995-1997 as the reference category.

\begin{tabular}{|c|c|c|c|c|}
\hline & Tubes 0-11 months & & Tubes $12-23$ months & \\
\hline & OR $(95 \% \mathrm{CI})$ & Sig. & OR $(95 \% \mathrm{CI})$ & Sig. \\
\hline 1998-2000 & $0.890(0.849-0.932)$ & $<0.0005$ & $0.977(0.957-0.997)$ & 0.026 \\
\hline $2001-2003$ & $0.967(0.924-1.012)$ & $<0.147$ & $1.025(1.004-1.046)$ & 0.019 \\
\hline \multirow[t]{3}{*}{ 2004-2007 } & $1.198(1.150-1.249)$ & $<0.0005$ & $1.112(1.100-1.145)$ & $<0.0005$ \\
\hline & $\begin{array}{l}\text { Adenoidectomy } \\
\text { 0-11 months }\end{array}$ & & $\begin{array}{l}\text { Adenoidectomy } \\
12-23 \text { months }\end{array}$ & \\
\hline & OR (95\% CI) & Sig. & OR (95\% CI) & Sig. \\
\hline 1998-2000 & $0.887(0.845-0.930)$ & $<0.0005$ & $0.982(0.964-0.999)$ & 0.044 \\
\hline 2001-2003 & $0.735(0.700-0.773)$ & $<0.0005$ & $0.933(0.916-0.950)$ & $<0.0005$ \\
\hline 2004-2007 & $0.724(0.691-0.759)$ & $<0.0005$ & $0.890(0.875-0.905)$ & $<0.0005$ \\
\hline
\end{tabular}


are a little higher in the periods thereafter. At the same time there is a significant gradual decrease in the odds for a child in this age group to undergo an adenoidectomy.

\section{DISCUSSION}

Our results indicate that there are still a substantial number of children being treated surgically for $\mathrm{OM}$ in the Netherlands.

Engel suggested in 1999 that a peak in number of children treated at an age of 15 months followed the screening for hearing impaired at the age of nine months ${ }^{4}$. This peak incidence in treatment at this age has also been found in Finland and Norway by Haapkyla ${ }^{8}{ }^{9}$. We analysed the number of children treated surgically for OM aged 0-23 months per month as Engel did, to investigate whether the disappearance of the hearing screen at 9 months of age around 2004 would affect the rate of treatment. As Engel did, we found a peak in the number of children treated around the age of 15 months. In our study the number of children treated with tubes aged 12-17 months stayed high even after termination of the screen at 9 months. The number of children treated with adenoidectomy aged 12-17 months however did decrease substantially in this period. The hypothesis that the peak incidence in treatment at the age of 15 months can fully be attributed to the screening at nine months is therefore not substantiated. Examination of the percentages of children treated, to adjust for fluctuations in national birth rates, reveals that there is a trend towards increased percentages of children being treated with ventilation tubes while a decrease in percentages of children being treated with adenoidectomy was observed.

It must be taken into consideration that there was a change in timing as well as method of screening for hearing impairment resulting in different referral percentages. The screening using the distraction hearing tests (CAPAS and Ewing) has resulted in relatively high referral percentages of 5-7\% (data from NSDSK, 1995-2004) attributed to fails caused by $\mathrm{OM}^{7}$. Neonatal screening, with otoacoustic emissions and automated auditory brainstem response, has referral percentages of only $0.5 \%$ (NSDSK, annual report 2006 ${ }^{10}$ ). Because of this low referral percentage we expected a decline in the number of children treated surgically for OM. Neonates do have OM but 
failing the neonatal screen is most often due to perceptive hearing loss ${ }^{11}$. Nevertheless an increase in the number of children treated with tubes was found. However, the decrease in adenoidectomies may point towards a shift in preference of type of treatment while the rate of treatment remained stable.

There are some limitations regarding our findings. The number of surgical procedures for the years 2005-2007 was estimated because some hospitals in the Netherlands had chosen not to make their data available to the National Medical Registration after the introduction in 2005 of the Diagnosis Treatment Combination, a new registration system, in the Netherlands. However, our estimations of the data, which was less complete, still resulted in consistent trends for both procedures.

Comparable results were found in a study assessing the number of surgical procedures for OM in Finland and Norway ${ }^{9}$. In these studies the decreasing numbers of adenoidectomy were explained by the change in national guidelines, in which there was less emphasis on the positive effect of adjuvant adenoidectomy in treatment of OM in young children. In the Netherlands there was no change in national guidelines for OM treatment and the increase of surgery for OM seems to coincide with the replacement of the hearing screen at the age of 9 months by a neonatal screen. In the present study the number of children aged 6-11 months treated with tubes increased with $25 \%$. It seems that children are being treated at a younger age since the introduction of the neonatal screen but we cannot attribute this effect to this screen because of its low referral percentage. The fact that these children are being referred to the ENT specialist and treated surgically for OM may reflect the problem general practitioners and specialists have with young infants. The medical field might be leaning more towards addressing the hearing loss accompanying otitis media rather than other symptoms. A recent publication of the Cochrane Collaboration discusses populationbased screening of asymptomatic children with $\mathrm{OM}^{12}$ and concludes that it is not useful. However there seems to be a subgroup of children that do need treatment. Children with recurrent acute otitis media are clearly symptomatic and can benefit from treatment ${ }^{13}$. Children with OM can have a substantial hearing loss ${ }^{14}$ and be asymptomatic because parents cannot detect hearing loss in their infants ${ }^{15,16}$. These children might be considered as needing 
treatment because it has been reported that treatment of hearing loss caused by OM does improve speech development ${ }^{17}$.

Testing hearing impairment in infants is time consuming and requires trained personnel and special equipment. It could be that, in the absence of a hearing screen at the age of nine months, general practitioners, missing this safety net of an oncoming screening, will more easily refer an infant to the ENT department when they suspect OM induced hearing loss. When the hearing screen at 9 months was still common practice, the general practitioner as well as the ENT specialist knew that the children referred to them did indeed have a chronic hearing problem caused by OM. With this information now lacking, doctors are possibly more cautious and as a result refer or treat children more readily and thus sooner for OM.

In contrast, the number of children treated with adenoidectomy declined after the disappearance of the screening at nine months. Perhaps this is a reflection of the dilemma presented to ENT specialists. Although treatment with tubes combined with adenoidectomy could be preferable for a child who has hearing impairment caused by $\mathrm{OM}^{18,19,20}$, adenoidectomy is a procedure with more risks. This may explain why specialists, when in doubt, prefer treatment with tubes only. It might also be because of recent studies questioning the effect of adjuvant adenoidectomy in the treatment of children with $\mathrm{OM}^{21,22}$, that fewer children are treated with adenoidectomy.

Our study shows that many children are still treated surgically for OM in the Netherlands. We can only speculate as to why the number of young infants treated with tubes has increased in spite of recent studies questioning the need for treatment in children with $\mathrm{OM}^{2,3,12,13,17,18,21,22}$. However we think that consensus exists among the general practitioners and ENT specialists that there is a group of young children with OM that do need treatment. Therefore a case-finding instrument that would enable general practitioners to determine which children with OM should be referred to the ENT department could be a valuable tool. 


\section{CONCLUSION}

Our study investigates the relation between the replacement of the hearing screen at the age of 9 months by a neonatal screen and the number of infants treated with tubes and/or adenoidectomy. The number of infants treated with tubes around the age of 15 months did not decline, as we had expected, and more children were treated at a younger age. The number of children treated with adenoidectomy however did decline.

We think that these results reflect the problem doctors have in diagnosing $\mathrm{OM}$ with chronic hearing loss in very young infants. Therefore we emphasize the need for an instrument that detects those infants with chronic OM and related hearing loss who are in need of treatment. 


\section{REFERENCES}

1. Paradise JL, Rockette HE, Colborn DK, Bernard BS, Smith CG, Kurs-Lasky M, et al. Otitis media in 2253 Pittsburgh-area infants: prevalence and risk factors during the first two years of life. Pediatrics 1997;99(3):318-33.

2. Rovers MM, Schilder AG, Zielhuis GA, Rosenfeld RM. Otitis media. Lancet 2004;363(9407):465-73.

3. Schilder AG, Lok W, Rovers MM. International perspectives on management of acute otitis media: a qualitative review. Int J Pediatr Otorhinolaryngol 2004;68(1):29-36.

4. Engel JAM, Anteunis LJC, Hendriks JJT. Treatment with grommets in the Netherlands. Incidence in children from birth to 12 years. Otitis Media Today; Proceedings of the Third Extraordinary Symposium on Recent Advances in Otitis Media 1997;Copenhagen,June 1-5, 1997(1999 Kugler Publications/The Hague/The Netherlands):451-455.

5. Engel J, Anteunis L, Volovics A, Hendriks J, Marres E. Prevalence rates of otitis media with effusion from 0 to 2 years of age: healthy-born versus highrisk-born infants. Int J Pediatr Otorhinolaryngol 1999;47(3):243-51.

6. Zielhuis GA, Rach GH, van den Bosch A, van den Broek P. The prevalence of otitis media with effusion: a critical review of the literature. Clin Otolaryngol Allied Sci 1990;15(3):283-8.

7. Rovers MM, Zielhuis GA, Straatman H, Ingels K, van der Wilt GJ, Kauffmande Boer M. Comparison of the CAPAS and Ewing tests for screening of hearing in infants. J Med Screen 1999;6(4):188-92.

8. Haapkyla J, Karevold G, Kvaerner KJ, Pitkaranta A. Finnish adenoidectomy and tympanostomy rates in children; national variation. Int J Pediatr Otorhinolaryngol 2006;70(9):1569-73.

9. Haapkyla J, Karevold G, Kvaerner KJ, Pitkaranta A. Trends in otitis media surgery: a decrease in adenoidectomy. Int J Pediatr Otorhinolaryngol 2008;72(8):1207-13.

10. Nederlandse Stichting van het Dove en Slechthorende Kind (NSDSK). Annual report 2006. http://www.nsdsk.nl/view/publicaties/jaarverslagen/nsdsk_jaarverslag_2006/.

11. Doyle KJ, Rodgers P, Fujikawa S, Newman E. External and middle ear effects on infant hearing screening test results. Otolaryngol Head Neck Surg 2000;122(4):477-81.

12. Simpson SA, Thomas CL, van der Linden MK, Macmillan H, van der Wouden JC, Butler C. Identification of children in the first four years of life for early treatment for otitis media with effusion. Cochrane Database Syst Rev 2007(1):CD004163.

13. McDonald S, Langton Hewer CD, Nunez DA. Grommets (ventilation tubes) for recurrent acute otitis media in children. Cochrane Database Syst Rev 2008(4):CD004741.

14. Fria TJ, Cantekin EI, Eichler JA. Hearing acuity of children with otitis media with effusion. Arch Otolaryngol 1985;111(1):10-6.

15. Anteunis LJ, Engel JA, Hendriks JJ, Manni JJ. A longitudinal study of the validity of parental reporting in the detection of otitis media and related hearing impairment in infancy. Audiology 1999;38(2):75-82. 
16. Rosenfeld RM, Goldsmith AJ, Madell JR. How accurate is parent rating of hearing for children with otitis media? Arch Otolaryngol Head Neck Surg 1998;124(9):989-92.

17. Rovers MM, Straatman H, Ingels K, van der Wilt GJ, van den Broek P, Zielhuis GA. The effect of ventilation tubes on language development in infants with otitis media with effusion: A randomized trial. Pediatrics 2000;106(3):E42.

18. Kadhim AL, Spilsbury K, Semmens JB, Coates HL, Lannigan FJ. Adenoidectomy for middle ear effusion: a study of 50,000 children over 24 years. Laryngoscope 2007;117(3):427-33.

19. Boston M, McCook J, Burke B, Derkay C. Incidence of and risk factors for additional tympanostomy tube insertion in children. Arch Otolaryngol Head Neck Surg 2003;129(3):293-6.

20. Coyte PC, Croxford R, McIsaac W, Feldman W, Friedberg J. The role of adjuvant adenoidectomy and tonsillectomy in the outcome of the insertion of tympanostomy tubes. N Engl J Med 2001;344(16):1188-95.

21. Hammaren-Malmi S, Saxen H, Tarkkanen J, Mattila PS. Adenoidectomy does not significantly reduce the incidence of otitis media in conjunction with the insertion of tympanostomy tubes in children who are younger than 4 years: a randomized trial. Pediatrics 2005;116(1):185-9.

22. Mattila PS, Joki-Erkkila VP, Kilpi T, Jokinen J, Herva E, Puhakka H.

Prevention of otitis media by adenoidectomy in children younger than 2 years. Arch Otolaryngol Head Neck Surg 2003;129(2):163-8. 


\section{CHAPTER 3}

\section{Screening for hearing loss versus parental concern because of ear and/or hearing problems and subsequent referral and treatment for otitis media in the Netherlands}

W. Lok, L.J.C. Anteunis, M.N. Chenault, Cor Meesters, Mark P. Haggard Submitted for publication and under revision 


\begin{abstract}
Introduction Ear and/or hearing problems are highly prevalent in infants, and a common reason to consult the general practitioner (GP). This study analyzes GP consultation and subsequent referral to an Ear, Nose and Throat (ENT) department and surgical treatment for otitis media (OM) in the Netherlands, whereby GP consultation could be initiated by failing the population hearing screen at nine months of age or by parental concern over ear/hearing problems. We were especially interested if failing the hearing screen increased the odds of a child being surgically treated for OM.
\end{abstract}

Methods A questionnaire covering the history between birth and 21 months of age was used to obtain information on referral after failing the hearing screen, GP consultations with ear/hearing problems, and subsequent referral to a specialist and possible surgical treatment at an ENT department. This questionnaire was sent to the 3681 respondents in an earlier study called PEPPER (Persistent Ear Problems, Providing Evidence for Referral, response rate $58 \%$ ).

Results The response rate for the present questionnaire was $72 \%$. Of all children tested, 3.9\% failed the hearing screen and were referred to their GP. Of all 2619 children in this study, 18.6\% visited their GP with ear/hearing problems. Eventually, $34.6 \%$ of all children visiting their GP with ear/hearing problems were referred further to a specialist. Children failing the hearing screen without GP consultation for ear/hearing problems were significantly more often treated surgically for OM than children passing the hearing screen but with GP consultation for ear/hearing problems.

Conclusion Objectified hearing loss, i.e. failing the hearing screen, was important in deciding for surgical treatment in infants in the Netherlands. 


\section{INTRODUCTION}

Ear and/or hearing problems caused by otitis media (OM) are highly prevalent in young children ${ }^{1-4}$ and represent about $1 / 5$ of all general practitioner (GP) visits in children 0-2 years in the Netherlands (www.nivel.nl). Until 2006 all children in the Netherlands were screened for hearing loss at the age of nine months. Most cases failing this screen had a conductive hearing loss due to otitis media ${ }^{5-7}$ and failing this hearing screen prompted GP consultation.

In the Netherlands the GP acts as a gatekeeper and the Ear, Nose and Throat (ENT) specialist is seldom consulted for small children without first being referred by the $\mathrm{GP}^{8}$. Before the replacement of the hearing distraction test at nine months by the neonatal screen, referrals to the ENT specialist could therefore be initiated by parental concern regarding ear and/or hearing problems, or by failing the hearing screen at nine months. Understanding these referral pathways has become of present interest because the number of young children treated with ventilation tubes in the Netherlands actually increased after the neonatal screen was introduced ${ }^{9}$, although no causal relationship has been proven. It was hypothesized that, in the absence of an imminent hearing screen at nine months of age, GPs would more readily refer infants to the ENT department. This could then lead to earlier referral, and therefore to earlier surgical treatment of OM.

The present study investigates whether the result of the hearing screen was important in deciding on referral and/or surgical treatment of OM.

\section{METHODS}

\section{Hearing screen}

The hearing distraction test (CAPAS, Compact Amsterdam PaedoAudiometrical Screening ${ }^{7}$ ) was conducted in the Netherlands at age nine months until 2005-2006. Children were referred to their GP upon either failing the CAPAS three times or failing twice when combined with other problems warranting referral, for example developmental problems or a suspected severe hearing loss. The GP could thereafter refer the child to a specialist directly, or opt for watchful waiting. 


\section{Subjects}

The potential sample consisted of 3681 children, born between 1-6-2004 until 31-12-2004 in the province of Limburg, Netherlands, whose parents had already participated in the 'Persistent Ear Problems, Providing Evidence for Referral' (PEPPER) study ${ }^{10}$ by returning the PEPPER questionnaire (6531 children received a questionnaire, response rate 56\%). The PEPPER study uses risk factors to predict OM-related hearing loss. For the present study those parents that returned the PEPPER questionnaire received a second questionnaire by mail when the children reached the age of 21 months. This structured history questionnaire was sent together with a letter explaining the purpose of the study and a stamped return envelope. Therefore the present study population consists of potentially 3681 children born from 1-6-2004 until 31-12-2004 whose parents received both questionnaires.

\section{Questionnaire}

The structured history questionnaire sent to the parents at age 21 months comprised 12 questions about attending the hearing screen, referral subsequent to this hearing screen, visits to the GP because of suspected ear and/or hearing problems and subsequent referral to a specialist (ENT specialist, paediatrician, or audiology department etc.) and treatment by an ENT specialist. See Appendix A. The data from the questionnaires was incorporated into an SPSS data file.

\section{Statistical analysis}

Four groups of children were defined for comparison.

Group one: children failing the hearing screen and with subsequent referral to their GP, no parent- initiated GP consultation about ear/hearing problems independent of the hearing screen.

Group two: children failing the hearing screen and with subsequent referral to their GP, and also with parent-initiated GP consultation about ear/hearing problems.

Group three: children passing the hearing screen but with parent-initiated GP consultation about ear/hearing problems. 
Group four: children passing the hearing screen and with no parent-initiated GP consultation about ear/hearing problems.

We were especially interested in whether or not failing the hearing screen increased the odds of surgical treatment for OM and we therefore calculated Odds Ratio's (ORs) for surgery and for tube placement for groups one and two, separately, relative to group three (SPSS 15.0).

\section{RESULTS}

A total of 2684 (72.9\%) parents returned the structured history questionnaire; 65 had completed it for a non-index child, leaving 2619 usable cases. (Figure 1).

Figure 1. Flow chart.

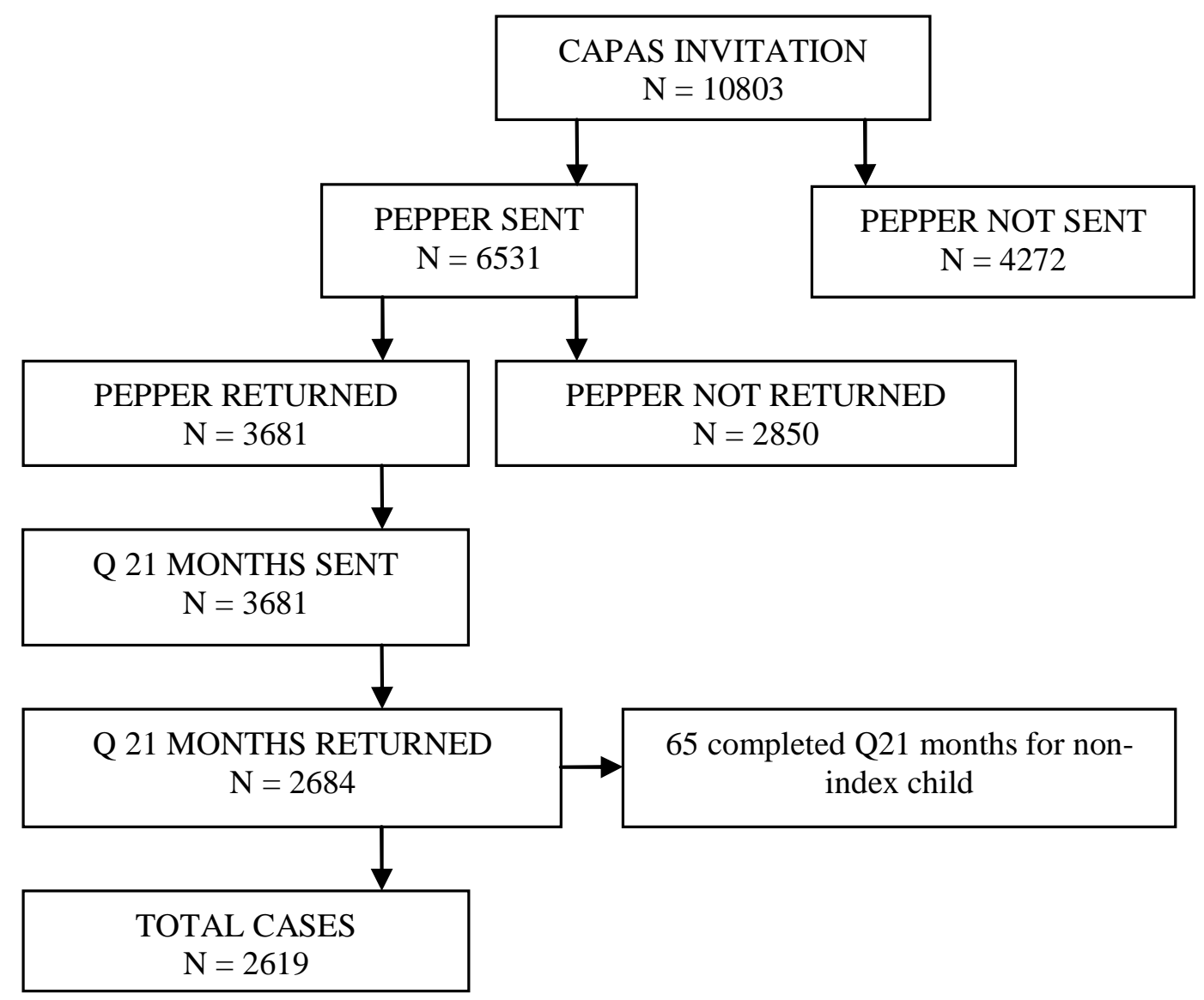




\section{Hearing screen and subsequent referral to the general practitioner}

Most children (74\%) were screened only once. According to the parents, 132 children were tested three times or more (5\%) and 144 children (5.5\%) were not tested at all.

Of all children in our study, a total of 102 children (3.9\%) were referred by the well-baby clinic to their GP of which 79 were then further referred to a specialist; 74 were referred directly, 3 after 1 month, 1 after 2 months and 1 after 3 months (parent reported data).

\section{General practitioner consultation for ear and/or hearing problems}

In total, 488 (18.6\%) children consulted their GP with ear and/or hearing problems. Table 1 presents the number of children with ear/hearing problems according to the age at the first visit to the GP. Of these 488 children, 24 (4.9\%) had also failed the hearing screen and were therefore referred to their GP. Fourteen of these 24 children (58\%) had consulted their GP before the hearing screen at the age of nine months.

Table 1. Number of children according to the age at the time of the first visit to the GP with ear/hearing problems. Subsequent referral to a specialist (audiology and/or ENT) and/or surgical treatment by an ENT specialist for children that visited their GP with ear/hearing problems at a certain age for the first time. Percentages according to the total number of children in a certain age group, i.e. age at first visit to the GP with ear/hearing problems. Parent reported data. (\%)

\begin{tabular}{|c|c|c|c|c|c|c|}
\hline & $\begin{array}{c}\text { Nof } \\
\text { children }\end{array}$ & $\begin{array}{l}\text { Referral to } \\
\text { a specialist }\end{array}$ & $\begin{array}{l}\text { Referral to } \\
\text { audiology }\end{array}$ & $\begin{array}{l}\text { Referral to } \\
\text { ENT }\end{array}$ & $\begin{array}{c}\text { ENT } \\
\text { surgery* }\end{array}$ & Tubes** \\
\hline \multicolumn{7}{|l|}{$\begin{array}{l}\text { Age at first } \\
\text { visit to GP }\end{array}$} \\
\hline$<3$ months & 20 & $15(75.0)$ & $2(10.0)$ & $12(60.0)$ & $11(55.0)$ & $10(50.0)$ \\
\hline 3-6 months & 64 & $22(34.4)$ & $3(4.7)$ & $19(29.7)$ & $16(25.0)$ & $14(21.9)$ \\
\hline 6-9 months & 90 & $43(47.8)$ & $2(2.2)$ & $39(43.3)$ & $36(40.0)$ & $30(33.3)$ \\
\hline 9-12 months & 90 & $28(31.1)$ & 1 (1.1) & $27(30.0)$ & $16(17.8)$ & $13(14.4)$ \\
\hline $12-15$ months & 116 & $27(23.3)$ & $1 \quad(0.9)$ & $27(23.3)$ & $21(18.1)$ & $18(15.5)$ \\
\hline$>15$ months & 108 & $34(31.5)$ & $3(2.8)$ & 29 (26.9) & $15(13.9)$ & $13(12.0)$ \\
\hline $\begin{array}{l}\text { Total } N \text { of children } \\
\text { visiting their GP }\end{array}$ & 488 & $169(34.6)$ & $12(2.5)$ & $153(31.4)$ & $115(23.6)$ & $98(20.1)$ \\
\hline Total $N$ of children & 2619 & $261(10.0)$ & 32 (1.2) & $204 \quad(7.8)$ & 169 (6.5) & $138 \quad(5.3)$ \\
\hline
\end{tabular}

$\mathrm{GP}=$ general practitioner; $\mathrm{ENT}=$ ear, nose and throat

* Surgical treatment for ENT problems

** Tubes with/without adenoidectomy or adenotonsillectomy 


\section{Referral to a specialist}

Of the 488 children consulting their GP with ear/hearing problems 261

children were referred further to a specialist, mostly to ENT (77.8\%), 12.3\% to audiology, $18.4 \%$ to paediatrics and $2.3 \%$ to another specialist (ophthalmologist, dermatologist, plastic surgeon, not specified). Only 17 children were referred to more than one specialist, mostly $(\mathrm{N}=14)$ to the ENT and paediatric department. Of the 261 children who were referred to a specialist, 79 were referred after failing the hearing screen.

Of the 204 children referred to ENT, 83 were treated with medication and 169 with surgery (Table 2).

Table 2. Number of children treated surgically for ENT problems.

\begin{tabular}{lrr}
\hline Surgical procedure & N $(\mathbf{\%})$ \\
\hline Adenoidectomy & $13(7.7)$ \\
Adenoidectomy and tubes & $51(30.2)$ \\
Adenotonsillectomy & $8(4.7)$ \\
Adenotonsillectomy and tubes & $10(5.9)$ \\
Tubes & $77(45.6)$ \\
Other $*$ & $10(5.9)$ \\
Total & $\mathbf{1 6 9}$
\end{tabular}

* abscess drainage, frenulum lingua dissection, paracentesis, laryngoscopy, excision sublingual cyst, cochlear implantation, suturing of the ear canal, cleaning of the ear canal.

Table 3 shows the numbers of children in the defined groups and the number of children referred and/or treated within each group. Children in group 1 (failing the hearing screen without previous parent-initiated GP consultation because of ear/hearing problems) were more often referred, and had a 2.9 higher odds ( $\mathrm{p}<0.0005$, CI: 1.73- 4.94) of undergoing tube placement than children in group 3 (passing the hearing screen and with a parent-initiated GP consultation because of ear/hearing problems). Children failing the hearing screen followed by referral and GP consultation because of ear/hearing problems (group 2) had a 6.1 higher odds ( $p<0.0005$, CI: 2.7613.28) of being treated with tubes than children who consulted the GP because of ear/hearing problems without failing the hearing screen (group 3). 
Table 3. Number of children in different groups that were referred to a specialist, respectively audiology, ENT specialist, respectively underwent ENT surgery or were treated surgically with tubes.

Percentages according to the total number of children in groups 1-4.

\begin{tabular}{lrrrrrrr}
\hline & Total N & $\begin{array}{l}\text { Referral to } \\
\text { specialist }\end{array}$ & $\begin{array}{l}\text { Referral to } \\
\text { audiology }\end{array}$ & $\begin{array}{l}\text { Referral } \\
\text { to ENT }\end{array}$ & \multicolumn{2}{l}{$\begin{array}{l}\text { Surgical ENT } \\
\text { treatment* }\end{array}$} & \\
\hline Group 1 & 74 & $56(75.7 \%)$ & $16(21.6 \%)$ & $36(48.6 \%)$ & $30(40.5 \%)$ & $29(39.2 \%)$ \\
Group 2 & 28 & $26(92.9 \%)$ & $5(17.9 \%)$ & $22(78.6 \%)$ & $19(67.9 \%)$ & $16(57.1 \%)$ \\
Group 3 & 460 & $145(31.5 \%)$ & 6 & $(1.3 \%)$ & $132(28.7 \%)$ & $94(20.4 \%)$ & $83(18.0 \%)$ \\
Group 4 & 2057 & $34(1.7 \%)$ & 5 & $(0.2 \%)$ & $14(0.7 \%)$ & $25(1.2 \%)$ & 11 \\
Total & $\mathbf{2 6 1 9}$ & $\mathbf{2 6 1}$ & $\mathbf{3 2}$ & $\mathbf{2 0 4}$ & $\mathbf{1 6 9}$ & $\mathbf{1 3 8}$ \\
\hline
\end{tabular}

Group 1: children failing the hearing screen and referred to the GP, no parent initiated GP consult regarding ear/hearing problems

Group 2: children failing the hearing screen and referred to the GP, parent initiated GP consult regarding ear/hearing problems

Group 3: children passing the hearing screen and parent initiated GP consult regarding ear/hearing problems

Group 4: children passing the hearing screen and no parent initiated GP consult regarding ear/hearing problems

ENT=ear, nose and throat department, GP-general practitioner

* Surgical treatment for ENT problems

** Tubes with/without adenoidectomy and/or adenotonsillectomy

\section{DISCUSSION}

The relationship between screening for hearing loss at the age of nine months and subsequent treatment with tubes has been discussed before ${ }^{9,11}$, but definite conclusions could not be drawn. The present study intends to determine to what extent failing the hearing screen at nine months resulted in surgical treatment for $\mathrm{OM}$ in an attempt to better understand why the number of children treated surgically increased after the disbanding of the screen at nine months ${ }^{9}$.

The response rate in the current study was reasonable, almost $73 \%{ }^{12}$. We are however reporting on a subpopulation as only parents who had responded in the PEPPER study ${ }^{10}$ (response rate $56 \%$ ) received an invitation to participate in this study. Analysis revealed that parents who returned both questionnaires had a relatively higher SES, which usually is accompanied by a better health ${ }^{13}$. Returning both questionnaires could also reflect more concern regarding ear/hearing problems in general or specifically in their child, and this could then result in higher percentage of referrals. In our study the referral rate after failing the hearing screen was $3.9 \%$, compared to 
4.9\% in the Netherlands in 2004 (Dutch Society of the Deaf and Hearing impaired Children: NSDSK [Nederlandse Stichting voor het Dove en Slechthorende Kind]). Of all children in this study, $18.6 \%$ of the parents took the initiative to visit the GP for ear/hearing problems in their child. The incidence of ear/hearing complaints presenting to GPs in the Netherlands for 2004-2005 was respectively 21.5 and 20.7 per 100 children aged 0-2 years (www.nivel.nl). It thus seems that we have sampled a group of children who had relatively fewer ear/hearing complaints or whose parents had a lower incidence in visiting the GP compared to national data, and that this may indeed be due to the higher SES of the responders. This does not invalidate associations (risk factors) within the sample but may raises issues of generalisability.

If we compare the children failing the hearing screen followed by referral but without GP consultation because of ear/hearing problems (group one) to children who consulted the GP because of ear/hearing problems, not failing the hearing screen (group three), then more screen-failing children were treated with tubes. For those children who consulted their GP because of ear/hearing problems, again failing the hearing screen increased the odds of treatment with tubes (group two versus group three). It seems that objectified hearing loss was indeed important in deciding on referral and treatment with tubes, and therefore screening for hearing loss was linked to treatment with tubes.

Since the hearing screen at the age of nine months was abandoned in the Netherlands, the percentage children receiving tube placement has become higher over time while that for adenoidectomy is lower ${ }^{9}$. Similar results were found in Finland and Norway ${ }^{14}$, i.e. a decreasing number of adenoidectomies in both countries and an increase in number of tube placements in Finland. In Finland these changes could be partly explained by a change in national guidelines. As the guidelines did not change in the Netherlands, we feel that the cross-over in predominant surgery found in our study and in the study from Haapkyla ${ }^{14}$ is strongly suggestive of a shift in clinical rationale towards hearing rather than URTI. The decreasing number of adenoidectomy could also be explained by awareness of publications questioning the need for adjuvant adenoidectomy for $\mathrm{OM}^{15}$. 
Furthermore, since the replacement of the hearing screen at age of nine months, it was observed that more rather than less children are being treated at a younger age ${ }^{9}$. In the present study, consultation of the GP with ear/hearing problems before the age of nine months led to more referral to a specialist and more treatment with tubes compared to consultation after the age of nine months (referral to a specialist $46 \%$ resp. $27 \%$; treatment with tubes: $31 \%$ resp. $14 \%$ ). The higher number of young children being referred could reflect parental concern, but could also be an indicator of an early and therefore more severe or more persistent problem ${ }^{16-18}$. However, a recent study did not show an increase in the incidence of $\mathrm{OM}^{19}$.

The increased number of children treated at a younger age could reflect the GP's clinical uncertainty in assessing hearing in infants. Testing hearing in infants is difficult for GPs. Tympanometry can help in diagnosing the presence of $\mathrm{OM}^{20}$, although it does not give information on the hearing. It could be that in the absence of an objectified hearing test to triage children with OM, GPs have become risk-averse and refer more easily. Then, at the ENT-department, the OM simply is confirmed and children might be treated, probably including a number of cases where the OM could have resolved within a watchful waiting period as $\mathrm{OM}$ is very often a self-limiting disease. Taking into account the recent publications regarding the (absence of the) need for treatment in simple $\mathrm{OM}^{21}$ and existing OM guidelines in the Netherlands ${ }^{22}$, watchful waiting should have led to fewer children being surgically treated rather than more.

\section{CONCLUSION}

Referral after failing the hearing screen at nine months was accompanied by a raised probability of referral for $\mathrm{OM}$ and treatment with tubes. In the current absence of this screen at nine months, more children seem to be treated with tubes and at a younger age. To what extent this reflects clinical uncertainty in the absence of an audiometric evaluation is unclear, but there is no evidence supporting an increase in severe cases. 


\section{REFERENCES}

1. Engel J, Anteunis L, Volovics A, Hendriks J, Marres E. Prevalence rates of otitis media with effusion from 0 to 2 years of age: healthy-born versus highrisk-born infants. Int J Pediatr Otorhinolaryngol 1999;47:243-251.

2. Midgley EJ, Dewey C, Pryce K, Maw AR. The frequency of otitis media with effusion in British pre-school children: a guide for treatment. ALSPAC Study Team. Clin Otolaryngol Allied Sci 2000;25:485-491.

3. Paradise JL, Rockette HE, Colborn DKet al. Otitis media in 2253 Pittsburgharea infants: prevalence and risk factors during the first two years of life. Pediatrics 1997;99:318-333.

4. Zielhuis GA, Rach GH, Van den Broek P. The occurrence of otitis media with effusion in Dutch pre-school children. Clin Otolaryngol Allied Sci 1990;15:147-153.

5. Mott A, Emond A. What is the role of the distraction test of hearing? Arch Dis Child 1994;70:10-13.

6. Rovers MM, Straatman H, Zielhuis GA, Ingels K, van der Wilt GJ. Seasonal variation in the prevalence of persistent otitis media with effusion in one-yearold infants. Paediatr Perinat Epidemiol 2000;14:268-274.

7. Rovers MM, Zielhuis GA, Straatman H, Ingels K, van der Wilt GJ, Kauffmande Boer M. Comparison of the CAPAS and Ewing tests for screening of hearing in infants. J Med Screen 1999;6:188-192.

8. Jansen AG, Sanders EA, Schilder AG, Hoes AW, de Jong VF, Hak E. Primary care management of respiratory tract infections in Dutch preschool children. Scand J Prim Health Care 2006;24:231-236.

9. Lok W, Chenault MN, Anteunis LJ. Implementation of neonatal screening for hearing impairment: influence on pediatric otitis media surgery in The Netherlands. Int J Pediatr Otorhinolaryngol 2009;73:1090-1094.

10. Lok W, Anteunis LJC, Meesters C, Chenault MN, Haggard M. Otitis media and related hearing loss in young infants: risk factors in a large Dutch sample. Accepted for publication in Eur Arch Otolaryngol 2011.

11. Engel JA, Anteunis LJ. [Utilization of middle ear ventilatory tubes for children, ages 0-12 years, in the Netherlands during 1990-1994]. Ned Tijdschr Geneeskd 1999;143:902-905.

12. Eaker S, Bergstrom R, Bergstrom A, Adami HO, Nyren O. Response rate to mailed epidemiologic questionnaires: a population-based randomized trial of variations in design and mailing routines. Am J Epidemiol 1998;147:74-82.

13. Reijneveld SA. Reported health, lifestyles, and use of health care of first generation immigrants in The Netherlands: do socioeconomic factors explain their adverse position? J Epidemiol Community Health 1998;52:298-304.

14. Haapkyla J, Karevold G, Kvaerner KJ, Pitkaranta A. Trends in otitis media surgery: a decrease in adenoidectomy. Int J Pediatr Otorhinolaryngol 2008;72:1207-1213.

15. Hammaren-Malmi S, Saxen H, Tarkkanen J, Mattila PS. Adenoidectomy does not significantly reduce the incidence of otitis media in conjunction with the insertion of tympanostomy tubes in children who are younger than 4 years: a randomized trial. Pediatrics 2005;116:185-189. 
16. Alho OP, Oja H, Koivu M, Sorri M. Risk factors for chronic otitis media with effusion in infancy. Each acute otitis media episode induces a high but transient risk. Arch Otolaryngol Head Neck Surg 1995;121:839-843.

17. Daly KA, Brown JE, Lindgren BR, Meland MH, Le CT, Giebink GS. Epidemiology of otitis media onset by six months of age. Pediatrics 1999;103:1158-1166.

18. Marchant CD, Shurin PA, Turczyk VA, Wasikowski DE, Tutihasi MA, Kinney SE. Course and outcome of otitis media in early infancy: a prospective study. J Pediatr 1984;104:826-831.

19. Uijen JH, Bindels PJ, Schellevis FG, van der Wouden JC. ENT problems in Dutch children: trends in incidence rates, antibiotic prescribing and referrals 2002-2008. Scand J Prim Health Care 2011;29:75-79.

20. Johansen EC, Lildholdt T, Damsbo N, Eriksen EW. Tympanometry for diagnosis and treatment of otitis media in general practice. Fam Pract 2000;17:317-322.

21. Lous J, Burton MJ, Felding JU, Ovesen T, Rovers MM, Williamson I. Grommets (ventilation tubes) for hearing loss associated with otitis media with effusion in children. Cochrane Database Syst Rev 2005:CD001801.

22. Boomsma LJ, Rovers MM, van Balen FA, Wiersma T, Goudswaard AN. [The practice guideline 'Otitis media with effusion' (second revision) from the Dutch College of General Practitioners]. Ned Tijdschr Geneeskd 2007;151:267-268; author reply 268. 


\section{CHAPTER 4}

\section{Referral and treatment for otitis media in the Netherlands before and after the replacement of the hearing screen at age nine months.}




\begin{abstract}
Introduction In 2005 the hearing screen at age nine months was replaced by a neonatal hearing screen after which the number of children treated with tubes increased. This was unexpected as it had been assumed that tube placement was to a great extent due to hearing screen fails as the prevalence of otitis media peaks around 9 months. In this study two cohorts of infants will be considered, one having undergone the 9 month hearing screen and the other the neonatal screening, to gain understanding as to why this unexpected increase in treatment with tubes occurred.
\end{abstract}

Methods A questionnaire was used to obtain information regarding visits to the general practitioner (GP) and Ear, Nose, Throat (ENT) specialist and subsequent treatment for ear and/or hearing problems before and after implementation of the neonatal screen in two cohorts of infants, in addition to otitis media (OM-) related symptoms and risk factors. The first cohort was screened for hearing loss at age nine months (the 'distraction test cohort'). The second cohort was screened for hearing loss in the neonatal period (the 'neonatal screen cohort').

Results The odds for referral were higher in the 'neonatal screen cohort' (OR $1.33 ; \mathrm{p}=0.049)$ and there was a statistically significant shift $(\mathrm{p}<0.0001)$ towards infants being referred at a younger age. The odds for ENT treatment were also significantly higher in the 'neonatal screen cohort' (OR 1.49, $\mathrm{p}=0.007$ ), and, again, significantly more infants were treated at a younger age.

Conclusion After implementation of the neonatal screen, the incidence of OM-related GP consultation increased and visits occurred at a younger age. Furthermore, the incidence of OM-related referral and subsequent treatment increased and more infants were treated at a younger age. The absence of a hearing screen at nine months might lead to more clinical insecurity. This calls for a case-finding instrument to aid doctors in detecting those children with $\mathrm{OM}$ in need of further assessment. 


\section{INTRODUCTION}

Until 2005, all infants in the Netherlands were screened for hearing loss at the age of nine months by means of the distraction hearing screen. This screen was originally introduced to detect infants with a congenital or early acquired permanent conductive and/or sensorineural hearing loss. However most infants who failed the screen repeatedly did so because of otitis media $(\mathrm{OM}-)$ related hearing loss ${ }^{1-3}$, as the prevalence of $\mathrm{OM}$ is high in the second half of the first year of life ${ }^{4}$. The screen therefore functioned more as a tool to detect otherwise healthy infants with OM- related hearing loss without obvious signs or symptoms. After failing the hearing screen three times, infants were referred to their general practitioner (GP) who then decided if the infant should be referred for further assessment. A recent study showed that failing the hearing screen at nine months repeatedly, increased the odds for OM-related referral and treatment with tubes ${ }^{5}$.

In 2005 the hearing screen at age nine months was replaced by the neonatal hearing screen to detect and treat infants with congenital or early acquired sensorineural hearing loss at a much younger age. The neonatal screen is conducted in the first weeks of life in the child's home by means of the OAE (otoacoustic emissions) screen. The neonatal screen is very specific, resulting in very few screen positives $\left(<0.5 \%\right.$ referral to audiology centres $\left.{ }^{6}\right)$. In the absence of the screen at nine months, infants developing OM-related hearing loss may not be detected as parental suspicion of OM-related hearing loss is very low ${ }^{7,8}$. Nevertheless, after the replacement of the screen at nine months more children rather than less were treated with tubes and at a younger age ${ }^{9}$. This increase could reflect clinical uncertainty in the absence of a hearing evaluation, as there was no supportive evidence of an increase in severe cases of OM. Assessing hearing in the very young is difficult. Without an upcoming screen, GPs might refer infants more readily to the ENT department when they are unsure about the presence of OM-related hearing loss. This might result in earlier referral and therefore earlier surgical treatment of OM.

To investigate this increase in surgical treatment for OM we conducted a questionnaire study among two cohorts. The first cohort consisted of infants who were screened for hearing loss by means of the distraction hearing screen at age nine months in 2005 (the 'distraction test cohort'). The second 
cohort consisted of infants who were screened for hearing loss in the neonatal period in 2010 (the 'neonatal screen cohort'). Both cohorts received questionnaires with questions regarding risk factor items for $\mathrm{OM}$ and questions regarding visits to the GP or a specialist (ENT, paediatrician, audiology centre) and subsequent treatment for ear and/or hearing problems. Comparison of the two cohorts enables analysis of referral and treatment for ear and/or hearing problems before and after the disappearance of the distraction hearing screen at nine months. The objective is to answer why the replacement of the screen at nine months led unexpectedly to an increase in treatment rather than a decrease.

\section{METHODS}

\section{Study populations}

The 'distraction test cohort' consisted of children born between 1-6-2004 until 31-12-2004 in the province of Limburg, the Netherlands. These children were born before the implementation of the neonatal screen and were screened with the distraction hearing test (CAPAS) at age nine months. In this cohort, PEPPER ('Persistent Ear Problems, Providing Evidence for Referral') questionnaires were sent to all 6531 children who were routinely invited for the distraction hearing screen at age nine months in 2005. The parents of the 3681 children who completed the PEPPER questionnaire were sent a follow up questionnaire (Q21 questionnaire) at child's age 21 months. The 'neonatal screen cohort' consisted of 6000 children born in the province of Limburg, the Netherlands, after implementation of the neonatal hearing screen. A combination questionnaire (PEPPER and Q21) was sent by mail to these children at age 21-33 months in September 2010. These children were therefore born between 1-12-2007 and 30-11-2008.

\section{Questionnaires}

The PEPPER questionnaire, initially developed in the United Kingdom, embraces a wide range of OM-related factors in a single instrument for use in primary care and can be completed by the child's parents or guardians within 3 minutes (see appendix A). 
The Q21 questionnaire is a structured history questionnaire, consisting of 12 questions about attending the hearing screen and subsequent referral, visits to the GP for suspected ear and/or hearing problems and subsequent referral to a specialist (ENT specialist, paediatrician, or audiology centre, etc.) and treatment by an ENT specialist (see appendix B).

For the second study cohort the questionnaire consisted of the questions from the PEPPER questionnaire combined with the questions from the Q21 questionnaire.

Names were not included on the questionnaire sheet to maintain anonymity.

\section{Study protocol and inclusion criteria}

To obtain comparable samples, only children aged 21-26 months at the time of the completion of the questionnaire were considered for the present study as the children in the distraction screen cohort were 21-26 months during the completion of the Q21 questionnaire.

Excluded from the study database were children with sensorineural hearing loss or permanent conductive hearing loss and children with Down syndrome and cleft palate or other craniofacial malformations.

Early birth was defined as a gestational age of $<37$ weeks. In the event of extremely small counts in some response categories of the questionnaire, categories were combined, as noted in Appendix A. The items 'number of children in day care' and 'breastfeeding' were dichotomised into 'attending day care with $>4$ children' and 'exclusive breastfeeding at least 3 months'. The variables 'age at first ear infection' and 'age first hearing problem' have been dichotomized into these occurring before 9 months or not.

\section{Statistical Analysis}

The questionnaire data was incorporated into an SPSS data file for further analysis (PASW Statistics 18).

First the two cohorts were compared relative to child specific characteristics, which are all categorical values, using chi-square statistics. The two cohorts were further compared regarding GP consultation for ear/hearing problems, subsequent GP referral to a specialist and ENT surgery in general and tube placement and also relative to the age category in which the first GP consultation occurred. Logistic regression was applied with ENT treatment 
as the outcome variable to compare the children who had consulted the GP in the two cohorts relative to age at first visit to GP regarding ear/hearing problems. Furthermore related symptoms and background characteristics were analysed. In addition, the age at first referral and age of first surgical treatment were compared to determine the number of children treated within 3 months of referral.

Approval for this study was obtained from the Medical Ethical Commission of the Maastricht University Medical Centre.

Figure 1. Flowchart of all stages of inclusion for both the 'distraction test cohort' and the 'neonatal screen cohort'.
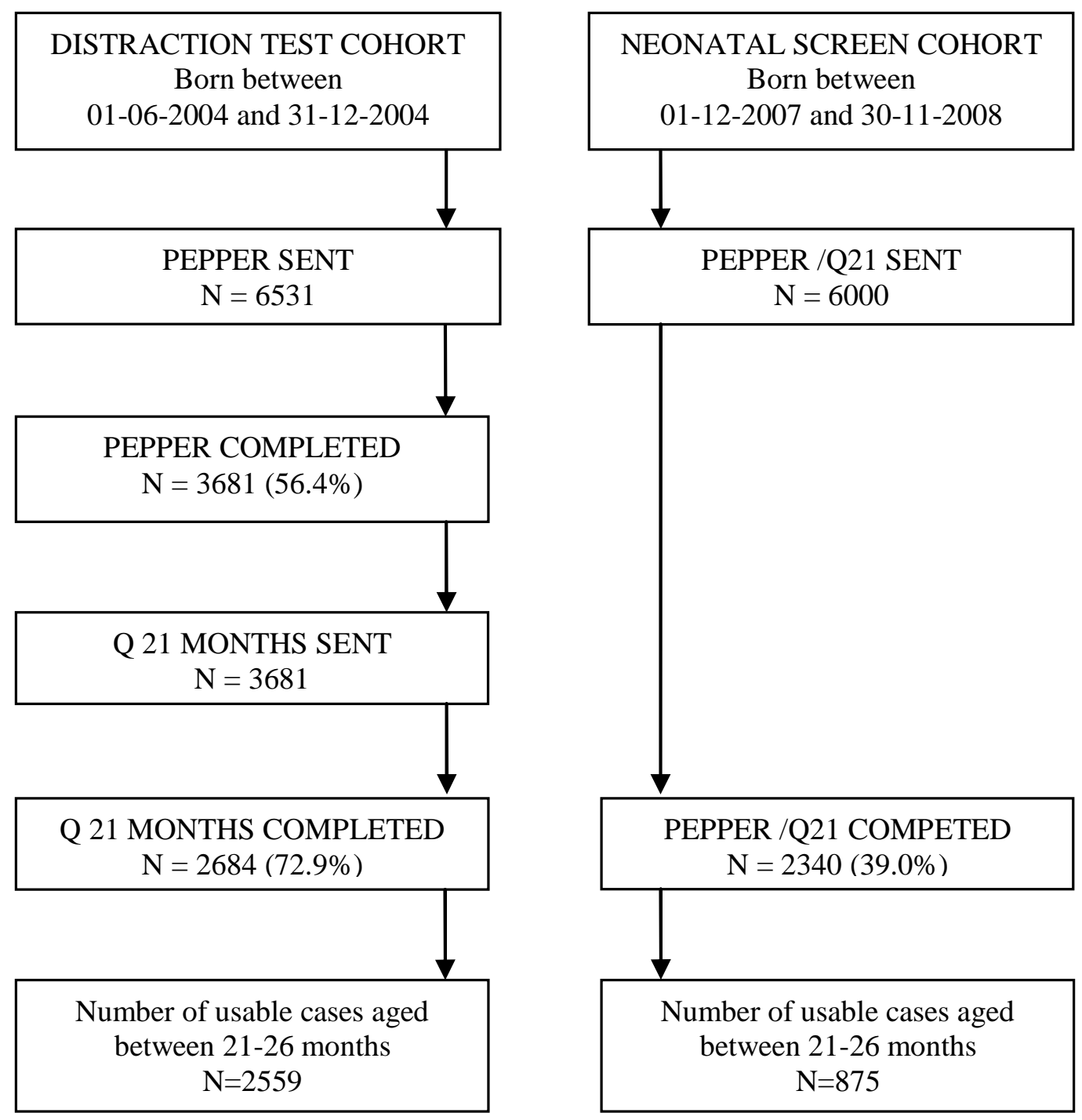


\section{RESULTS}

See Figure 1 for the flowchart with the number of children in both study cohorts.

In the 'distraction test cohort' children were screened for hearing loss at age nine months. In this cohort 100 (3.9\%) children failed the hearing screen repeatedly and were subsequently referred to their GP. In the 'neonatal screen cohort' children were screened for hearing loss in the neonatal period. In this cohort 798 (91.2\%) were screened at home (OAE) and $49(5.6 \%)$ were screened in a hospital (ALGO). Only $6(0.7 \%)$ failed the neonatal screen and were subsequently referred for further assessment.

Table 1. Reported risk factor symptoms, data of both study cohorts.

\begin{tabular}{|c|c|c|c|}
\hline & $\begin{array}{l}\text { Distraction test cohort } \\
\mathrm{N}(\%)\end{array}$ & $\begin{array}{l}\text { Neonatal screen cohort } \\
\mathrm{N}(\%)\end{array}$ & p-value \\
\hline Total & 2559 & 875 & \\
\hline Boys & $1266(49.5)$ & $463(52.9)$ & n.s. \\
\hline Early birth & $147 \quad(5.7)$ & $62 \quad(7.1)$ & n.s. \\
\hline $\begin{array}{l}\text { First ear infection } \\
0-9 \text { months }\end{array}$ & $376(14.7)$ & $244(27.9)$ & $<0.0005$ \\
\hline $\begin{array}{l}\text { First hearing problem } \\
0-9 \text { months }\end{array}$ & $60 \quad(2.3)$ & $41 \quad(4.7)$ & 0.002 \\
\hline $\begin{array}{l}\text { Ear infection last } 3 \text { months } \\
\text { Yes/no }\end{array}$ & $387(15.1)$ & $206(23.5)$ & $<0.0005$ \\
\hline $\begin{array}{l}\text { Ear infection past month } \\
\geq 1\end{array}$ & $198 \quad(7.7)$ & $66 \quad(7.5)$ & n.s. \\
\hline $\begin{array}{l}\text { Mouth breathing* } \\
\text { Nasal congestion* } \\
\text { Snoring* } \\
\text { Having cold symptoms* }\end{array}$ & $\begin{array}{l}257(10.0) \\
306(12.0) \\
204(8.0) \\
586(22.9)\end{array}$ & $\begin{array}{r}139(15.9) \\
97(11.1) \\
90(10.3) \\
138(15.8)\end{array}$ & $\begin{array}{l}<0.0005 \\
\text { n.s. } \\
\text { n.s. } \\
<0.0005\end{array}$ \\
\hline Smoking & & & \\
\hline $\begin{array}{l}\text { Mother } \\
\text { Father } \\
\text { Care taker } \\
\text { Other }\end{array}$ & $\begin{aligned} 116 & (4.5) \\
157 & (6.1) \\
36 & (1.4) \\
137 & (5.4)\end{aligned}$ & $\begin{array}{ll}30 & (3.4) \\
41 & (4.7) \\
11 & (1.3) \\
32 & (3.7)\end{array}$ & $\begin{array}{l}\text { n.s. } \\
\text { n.s. } \\
\text { n.s. } \\
0.045\end{array}$ \\
\hline $\begin{array}{l}\text { Cigarettes } \\
<20 \\
\geq 20\end{array}$ & $\begin{array}{r}265(10.4) \\
27 \quad(1.1)\end{array}$ & $\begin{array}{rr}59 & (6.7) \\
7 & (0.8)\end{array}$ & $\begin{array}{l}<0.0005 \\
\text { n.s. }\end{array}$ \\
\hline $\begin{array}{l}\text { Breastfeeding at least } 3 \\
\text { months } \\
\text { Only bottle feeding }\end{array}$ & $822(32.1)$ & $303(34.6)$ & n.s. \\
\hline $\begin{array}{l}\text { Day care }>4 \text { children } \\
\text { Having siblings }\end{array}$ & $\begin{array}{r}595(23.3) \\
1260(49.2)\end{array}$ & $\begin{array}{l}575(65.7) \\
506(57.8)\end{array}$ & $\begin{array}{l}<0.0005 \\
<0.0005\end{array}$ \\
\hline
\end{tabular}


Table 1 presents the child characteristics per cohort, whereby the children from the distraction test cohort completed the PEPPER questionnaire at age nine months and the neonatal cohort at age 21 months.

There are significant differences between both cohorts regarding parent reported complaints (ear infections, hearing problems, upper respiratory tract infections) and risk factors (smoking, day care, having siblings).

Both cohorts were also analysed to determine if more ear infections and/or hearing problems occurred between 0-5 months compared to 6-9 months, i.e. if there was a shift towards a younger age for these variables. This was not significantly different between the cohorts.

To investigate to what extent the differences in risk factors between the two cohorts influenced the estimated ORs for treatment with tubes, we calculated the ORs for each of these risk factors first for the whole sample with and without adjusting for cohort, whereby the reference category was the 'distraction test cohort'. In Table 2 the first column presents the OR for the whole dataset, the second column presents the OR adjusted for cohort. The ORs were unaltered after adjustment for cohort indicating that the differences between the cohorts did not affect the estimated ORs.

Table 2. Odds Ratio's for tube placement for those symptoms and risk factors which differed between the two cohorts.

\begin{tabular}{lcc}
\hline Risk factor item & OR & $\begin{array}{c}\text { OR } \\
\text { (adjusted for cohort) }\end{array}$ \\
\hline First ear infection 0-9 months & $7.47(5.61-9.94)$ & $7.40(5.54-9.90)$ \\
Hearing problems & $10.63(6.92-16.34)$ & $10.29(6.62-15.72)$ \\
Ear infection last 3 months & $5.46(4.11-7.25)$ & $5.33(4.01-7.09)$ \\
Severe mouth breathing & $3.28(2.38-4.51)$ & $3.17(2.30-4.36)$ \\
Severe cold symptoms & $3.41(2.57-4.52)$ & $3.60(2.71-4.78)$ \\
Cigarettes <20 & $1.05(0.66-1.68)$ & $1.10(0.69-1.75)$ \\
$\quad>20$ & $3.26(1.33-7.97)$ & $3.36(1.37-8.24)$ \\
Day care > 4 children & $1.52(1.10-2.11)$ & $1.44(1.02-2.02)$ \\
Having siblings & $1.86(1.39-2.48)$ & $1.81(1.36-2.42)$ \\
\hline
\end{tabular}


Table 3. Number of children visiting their GP with ear/hearing problems, number of children referred to a specialist by their GP and number of children treated (surgically) by an ENT specialist)

\begin{tabular}{|c|c|c|c|c|c|}
\hline & $\begin{array}{l}\text { Distraction } \\
\text { test cohort } \\
\mathbf{N}(\%)\end{array}$ & $\begin{array}{l}\text { Neonatal } \\
\text { screen cohort } \\
\mathbf{N}(\%)\end{array}$ & OR & 95\% C.I. & p-value \\
\hline GP visit ear/hearing problems & $478(18.7)$ & $192(21.9)$ & 1.224 & $(1.01-1.48)$ & 0.035 \\
\hline GP referral to a specialist* & $166(6.5)$ & $73 \quad(8.3)$ & 1.312 & $(0.99-1.75)$ & 0.063 \\
\hline ENT surgery & $145 \quad(5.7)$ & $(8.2)$ & 1.493 & $(1.11-2.00)$ & 0.007 \\
\hline Total N & 2559 & 875 & & & \\
\hline
\end{tabular}

*Distraction test cohort: audiology 30; paediatrician 44; ENT 198; other 6

Neonatal screen cohort: audiology 1; paediatrician 3; ENT 83

Table 3 shows data regarding GP consultation because of ear/hearing problems, subsequent referral and/or surgical treatment by an ENT specialist. In the 'neonatal screen cohort' the percentage of children consulting their GP with ear/hearing problems is higher, although the neonatal screen results in substantially less screen positives. The percentage of GP referral is not statistically significant different between the two cohorts, however relatively more children are treated surgically in the 'neonatal screen cohort'.

Table 4. Age of first GP visit because of ear/hearing problems and referral by the GP and treatment by an ENT specialist according to the age of the first GP visit for both cohorts.

\begin{tabular}{|c|c|c|c|c|c|c|}
\hline \multirow[b]{2}{*}{ Age* $^{*}$} & \multicolumn{2}{|c|}{ First visit to GP } & \multicolumn{2}{|c|}{$\begin{array}{l}\text { GP referral according } \\
\text { to age first visit GP }\end{array}$} & \multicolumn{2}{|c|}{$\begin{array}{l}\text { ENT treatment according } \\
\text { to age first visit GP }\end{array}$} \\
\hline & $\begin{array}{l}\text { Distraction } \\
\text { test }\end{array}$ & $\begin{array}{l}\text { Neonatal } \\
\text { screen }\end{array}$ & $\begin{array}{l}\text { Distraction } \\
\text { test }\end{array}$ & $\begin{array}{l}\text { Neonatal } \\
\text { screen }\end{array}$ & $\begin{array}{l}\text { Distraction } \\
\text { test }\end{array}$ & $\begin{array}{l}\text { Neonatal } \\
\text { screen }\end{array}$ \\
\hline 0 - 3 months & $19(0.7)$ & $16(1.8)$ & $14(0.5)$ & $10(1.1)$ & $12(0.5)$ & $12(1.4)$ \\
\hline months & $64 \quad(2.5)$ & (4.9) & $22(0.9)$ & $19(2.1)$ & 21( & 20 \\
\hline 7 - 9 months & $90 \quad(3.5)$ & (6.9) & 43 (1.7) & $20(2.3)$ & 40( & $19(2.2)$ \\
\hline 10 - 12 months & 86 (3.4) & (2.4) & $27(1.0)$ & $12(1.4)$ & $24(0.9)$ & $10(1.1)$ \\
\hline 13 - 15 months & 115 & (2.7) & $27(1.0)$ & $7(0.8)$ & $24(0.9)$ & $5(0.6)$ \\
\hline$>16$ months & $104 \quad(4.1)$ & $19 \quad(2.2)$ & $33(1.3)$ & $6(0.7)$ & $24(0.9)$ & $6(0.7)$ \\
\hline Total** & $478(18.7)$ & $183(20.9)$ & $166(6.5)$ & $74(8.5)$ & $145(5.6)$ & $72(8.2)$ \\
\hline
\end{tabular}

* first study slightly different age groups: $<3 ; 3-6 ; 6-9 ; 9-12 ; 12-15 ;>15$ months

In Table 4 data regarding GP consultation, GP referral and ENT treatment is presented. 
Although there is not a statistically significant difference between the two cohorts for GP consultation, within the 'neonatal screen cohort' there is a statistically significant shift towards infants visiting the GP for the first time at a younger age. The odds of visiting the GP for the first time at an age 0-3, 4-6 and 7-9 months was significantly higher in the 'neonatal screen cohort' and varied between 3.6 and $4.6(\mathrm{p}<0.0001)$.

Comparing both cohorts for the outcome 'referral to a specialist', the odds for referral are higher in the 'neonatal screen cohort' (OR 1.33; $\mathrm{p}=0.049$ ).

Furthermore, within the 'neonatal screen cohort' there is a statistically significant shift $(\mathrm{p}<0.0001)$ towards infants being referred for the first time at a younger age; the odds for referral at a younger age are significant higher in the 'neonatal screen cohort' (age 0-3 months: OR 3.9, $\mathrm{p}=0.024$; age 4-6 months: OR 4.7, $\mathrm{p}=0.004)$.

Comparing both cohorts for the outcome 'ENT treatment', the odds for ENT treatment are significant higher in the 'neonatal screen cohort' (OR 1.49, $\mathrm{p}=0.007)$. Again, in the 'neonatal screen cohort' significantly more younger infants are treated (0-3 months: OR 4.00, $\mathrm{p}=0.024 ; 4-6$ months: OR 3.8, $\mathrm{p}=0.016$ ).

Table 5. Odds Ratio's for tube placement for those children that consulted a GP, for those symptoms and risk factors which differed between the two cohorts

\begin{tabular}{lcc}
\hline Risk factor/symptom & OR & $\begin{array}{c}\text { OR } \\
\text { (adjusted for cohort) }\end{array}$ \\
\hline First ear infection 0-9 months & $1.73(1.25-2.40)$ & $1.65(1.17-2.33)$ \\
Hearing problems & $4.00(2.32-6.91)$ & $3.84(2.22-6.67)$ \\
Ear infection last 3 months & $1.47(1.06-2.03)$ & $1.42(1.02-1.97)$ \\
Severe cold symptoms & $1.92(1.38-2.69)$ & $2.03(1.42-2.85)$ \\
Severe mouth breathing & $2.39(1.60-3.56)$ & $2.31(1.54-3.45)$ \\
Cigarettes <20 & $1.21(0.69-2.12)$ & $1.23(0.70-2.16)$ \\
$\quad>20$ & $2.63(0.79-8.73)$ & $2.67(0.80-8.88)$ \\
Having siblings & $1.83(1.31-2.56)$ & $1.82(1.30-2.55)$ \\
Day care > 4 children & $1.52(1.10-2.11)$ & $1.44(1.02-2.02)$ \\
\hline
\end{tabular}

Table 5 presents the ORs for tube placement of the risk factors differing between the cohorts for the subset of children from both cohorts who consulted the GP regarding ear/hearing problems. The first column presents the unadjusted ORs while the second column presents the ORs adjusted for 
the cohort. Once again it appears that the ORs do not alter when adjusted for 'cohort', indicating that the calculated ORs are not biased by the differences in risk factors between the cohorts.

Analysing the time between the age of first referral to ENT and the age of first ENT treatment in the neonatal cohort revealed that more than $75 \%$ of all children referred and treated, were treated within 3 months after referral. We did not have this data for the distraction test cohort.

\section{DISCUSSION}

The present study shows that there are statistically significant differences in GP consultation because of ear and/or hearing problems, subsequent referral and/or surgical treatment before versus after the implementation of the neonatal screen in 2005-2006. The percentage of children consulting their GP with ear/hearing problems increased after implementation of the neonatal screen, as did the percentages of ENT treatment and ENT surgery because of ear/hearing problems. These differences in overall percentages could not be explained by differences in incidence of parent reported complaints (ear infections, hearing problems, upper respiratory tract infections) and risk factors (smoking, day care, having siblings) in both cohorts. Therefore we concluded that although the two cohorts differ in the presence of certain characteristics and symptoms, these differences do not alter the outcome. In the Netherlands, in the period 2007-2009, the incidence of otitis media related GP consultation was higher compared to the period 2004-2006 (national data, no data present regarding $2010^{10}$ ). These national data also show that, in the period 2007-2009, the incidence of otitis media related GP consultation increased relatively more in the 0-12 month old infants, than in the 1-4 year old children. This shift towards more infants visiting the GP with otitis media related problems after the replacement of the distraction hearing screen also concurs with the data of the 'neonatal screen cohort'. It appears then that 'the neonatal screen cohort' can be seen as a representative sample of the Dutch population of young children in the same period.

National data regarding risk factors in these young children are not available. In the present study the significant shift towards children consulting their GP 
with ear/hearing problems at a younger age in the 'neonatal screen cohort' was not accompanied by a shift towards a higher incidence of parent reported complaints at a younger age. The higher incidence of GP consultation found in our study as well as in the national data, could imply that help-seeking behaviour of parents has changed over time. This potential change in help-seeking behaviour of the parents, together with an absence of a hearing screen at age nine months could lead to more insecurity about the severity of the ear/hearing problems in these very young children. This then could lead to earlier referral to the ENT specialist. The higher incidence of GP consultation on its own could also lead to the reported higher incidence of referral. A higher incidence of referral at a younger age then results in a higher incidence of ENT treatment at a younger age, as more than $75 \%$ of all children referred and treated, were treated within 3 months after referral. However, taking into account the recent publications regarding the absence of the need for treatment in simple $\mathrm{OM}^{11-13}$ we would have expected fewer children being treated surgically.

\section{Study limitations}

The children from the 'distraction screen cohort' received two questionnaires, one (PEPPER) at age nine months and one (Q21) at age 21 months. The children from the 'neonatal screen cohort' received one combined questionnaire (PEPPER + Q21) at age 21-26 months, therefore the children in the second group ('neonatal screen cohort') were older when the PEPPER was completed, which may result in less accurate responses because parents had to recall information about events that occurred some time ago. The questionnaires for the 'neonatal screen cohort' were all sent in September, the questionnaires for the 'distraction test cohort' from May until February. This might result in differences in the incidence of upper respiratory tract infections and ear infections. For example the question regarding the number of ear infections in the last month or the presence of mouth breathing, snoring, etc. in the last 3 months might be answered differently depending on the season during which the questionnaire was completed.

There are some limitations in the generalizability of the results of the present study. This study was conducted in the Netherlands and ENT referral 
patterns and subsequent surgical rates might differ from those in other European countries.

The response rate in the 'distraction test cohort' was reasonable for the PEPPER questionnaire (56.4\%) and good for the Q21 questionnaire (72.9\%). Analysis revealed that parents who returned both questionnaires lived in areas with a relatively lower percentage migrant population, less unemployment, and higher incomes than parents who did not return both questionnaires. Therefore the results may not be typical for the whole population. Furthermore the 'distraction test cohort' consists of children who had relatively fewer ear/hearing complaints and whose parents had a lower incidence in visiting the GP compared to national data ${ }^{14}$. This may be due to the higher SES of the responders.

The response rate in the 'neonatal screen cohort' was poor (39\%). We did not investigate why parents did not return the questionnaire. But, when we compare our data with national data, the increase in incidence of ear/hearing problem-related GP consultation in the second study period is comparable, as is the shift towards children visiting their GP at a younger age. We therefore concluded that these response rates do not invalidate associations but may raise issues regarding the generalizability of our findings.

\section{CONCLUSION}

After implementation of the neonatal screen, the incidence of GP consultation because of ear and/or hearing problems in young children increased and children visited their GP at a younger age. This shift towards younger children visiting their GP with ear/hearing problems could not be explained by an increase in parent reported ear/hearing complaints nor by an increase in otitis media related risk factors. The present study also shows that the incidence of children being referred and subsequently treated because of ear/hearing problems increased after implementation of the neonatal screen. There is no conclusive evidence that the implementation of the neonatal hearing screen has caused these changes. However, the absence of a hearing screen at nine months could lead to more insecurity about the severity of the ear/hearing problems in these very young children, which then could lead to 
a higher incidence of GP consultation, a higher referral rate and a higher incidence of surgical treatment. If this is the explanation of the observed increase in referral and treatment, than there is a need for a case-finding instrument to assist in detecting those children with OM that need further assessment and possible treatment. 


\section{REFERENCES}

1. Mott A, Emond A. What is the role of the distraction test of hearing? Arch Dis Child 1994;70:10-13.

2. Rovers MM, Straatman H, Zielhuis GA, Ingels K, van der Wilt GJ. Seasonal variation in the prevalence of persistent otitis media with effusion in one-yearold infants. Paediatr Perinat Epidemiol 2000;14:268-274.

3. Rovers MM, Zielhuis GA, Straatman H, Ingels K, van der Wilt GJ, Kauffmande Boer M. Comparison of the CAPAS and Ewing tests for screening of hearing in infants. J Med Screen 1999;6:188-192.

4. Engel J, Anteunis L, Volovics A, Hendriks J, Marres E. Prevalence rates of otitis media with effusion from 0 to 2 years of age: healthy-born versus highrisk-born infants. Int J Pediatr Otorhinolaryngol 1999;47:243-251.

5. Lok W, Anteunis LJC, Chenault MN, Meesters C, Haggard MP. Screening for hearing loss versus parental concern because of ear and/or hearing problems and subsequent referral and treatment for otitis media in the Netherlands. Submitted for publication

6. van der Ploeg CPB, Rijpstra A. Monitoring of the neonatal hearing screen by the Youth Health Care in 2009 [Monitoring van de neonatale gehoorscreening door de jeugdgezondheidszorg in 2009]. TNO-rapport; KvL/P\&Z/2010.065 2009.

7. Rosenfeld RM, Goldsmith AJ, Madell JR. How accurate is parent rating of hearing for children with otitis media? Arch Otolaryngol Head Neck Surg 1998;124:989-992.

8. Anteunis LJ, Engel JA, Hendriks JJ, Manni JJ. A longitudinal study of the validity of parental reporting in the detection of otitis media and related hearing impairment in infancy. Audiology 1999;38:75-82.

9. Lok W, Chenault MN, Anteunis LJ. Implementation of neonatal screening for hearing impairment: influence on pediatric otitis media surgery in The Netherlands. Int J Pediatr Otorhinolaryngol 2009;73:1090-1094.

10. Verheij RA, Van Dijk CE, Stirbu-Wagner I et al. National Information netwerk General Practitioner care. Facts and numbers on General Practitioner care in the Netherlands. [Landelijk Informatienetwerk Huisartsenzorg. Feiten en cijfers over huisartsenzorg in Nederland.] Utrecht/Nijmegen: NIVEL/IQ, 2009, [http://www.nivel.nl/oc2/page.asp?pageid=14039], bezocht op $16 \mathrm{mei}$ 2011.

11. Rovers MM, Schilder AG, Zielhuis GA, Rosenfeld RM. Otitis media. Lancet 2004;363:465-473.

12. Lous J, Burton MJ, Felding JU, Ovesen T, Rovers MM, Williamson I. Grommets (ventilation tubes) for hearing loss associated with otitis media with effusion in children. Cochrane Database Syst Rev 2005:CD001801.

13. Simpson SA, Thomas CL, van der Linden MK, Macmillan H, van der Wouden JC, Butler C. Identification of children in the first four years of life for early treatment for otitis media with effusion. Cochrane Database Syst Rev 2007:CD004163.

14. Lok W, Anteunis LJC, Meesters C, Chenault MN, Haggard MP. Risk factors for failing the hearing screen due to otitis media in Dutch infants. Accepted for publication in European Arch Otolaryngol 2011. 


\section{CHAPTER 5}

\section{Risk factors for failing the hearing screen due to otitis media in Dutch infants}

W. Lok, L.J.C. Anteunis, C. Meesters, M.N. Chenault, M. P Haggard Accepted for publication in Eur Arch Otolaryngol, in press. 


\begin{abstract}
Introduction Hearing loss from otitis media (OM) can affect young children's development. Some children with persistent OM-related hearing loss and associated problems can benefit from treatment, but researchers and clinicians are still unclear on how to identify them best. The present study aims to determine which factors are most related to the hearing loss in OM, as a first step towards an effective case-finding instrument for detecting infants with persistent OM-related hearing loss.
\end{abstract}

Methods The full PEPPER ('Persistent Ear Problems, Providing Evidence for Referral') item pool includes a wide range of risk factors for OM in a single questionnaire, and is easily completed by parents or guardians. The questionnaire was sent to all children invited for the universal hearing screen at age 9 months in Limburg the Netherlands. Repeatedly failing of the hearing screen was used as outcome marker indicative of OM-related chronic hearing loss. Univariate analyses were conducted to determine statistically significant risk factors predicting 'fail' cases at this hearing screen.

Results Five items were found as individually predictive of hearing screen failure and subsequent referral: 'having severe cold symptoms', 'attending day care with $>4$ children', 'having siblings', 'severe nasal congestion' and 'male gender'.

Conclusion Suitably worded parental questions document risk factors for OM-related hearing loss in infants, broadly consistent with past general literature on OM risk factors, but more focused. The findings justify further optimising and evaluation of an additive or multiplicative combination of these questions as a means for selecting and routing an infant with diagnosed or suspected $\mathrm{OM}$ to further care. 


\section{INTRODUCTION}

Otitis media $(\mathrm{OM})$, highly prevalent in the first two years of life ${ }^{1-5}$, is characteristically fluctuating in duration ${ }^{1,3,6}$ and often accompanied by varying degrees of hearing loss ${ }^{7,8}$. OM-induced hearing loss often goes undiagnosed as parents are unable to recognise it ${ }^{9-11}$ and it can be detrimental to child development, including speech and language development, behaviour and the general quality of life of the child ${ }^{1,12-14}$. Until recently, screening for congenital or early acquired sensorineural or permanent conductive hearing loss, with an expected incidence of $<0.2 \%$, occurred at 9 months of age in the Netherlands. That screen had 5-7\% fails, mostly due to OM-related hearing loss (data from 1995-2004, Dutch Society of the Deaf and Hearing Impaired Child; NSDSK) ${ }^{15}$. Children failing the hearing screen repeatedly, were referred for treatment and many underwent tube insertion. Therefore, the screen also functioned as a tool for identification and treatment of persistent OM-related hearing loss. This hearing screen at 9 months of age has now been replaced by neonatal screening for earlier detection and rehabilitation of congenital hearing loss. Without the screen at age 9 months, detecting infants with hearing loss (e.g. due to $\mathrm{OM}$ ) developing after the neonatal period would be more difficult, so reduced numbers of children receiving tubes might be expected.

Surprisingly, however, more children, not fewer are now treated with tubes at a very young age since ${ }^{16}$. The reasons for this increase in the number of children treated are unknown, but could be related to clinical uncertainty with subsequent over-treatment, implying a need for further bases of selection.

The present study explores risk-factors for persistent OM-related hearing loss as a possible basis for selective referral from general practice. It uses a large sample of otherwise healthy young infants from the general Dutch population that was routinely invited for a population screen. Referral after a repeated hearing screen failure provides the relevant outcome. The approach is univariate, to help comparison with risk factors for OM.

\section{METHODS}

PEPPER item pool 
The PEPPER item pool ('Persistent Ear Problems, Providing Evidence for Referral'), initially developed in the United Kingdom, embraces a wide range of OM-related factors in a single instrument for use in primary care and can be completed by the child's parents or guardians within 3 minutes. To facilitate use, the items were pooled into the PEPPER questionnaire. The English version of this questionnaire (Appendix A) was translated into Dutch, and then back into English by an English native speaker.

\section{Universal hearing screen}

The hearing distraction test (CAPAS, Compact Amsterdam PaedoAudiometrical Screening, a screen at 35dB SPL based on visual reenforcement audiometry; see Rovers et al. ${ }^{15}$ for details) was a population screen conducted at age 9 months by special trained employees at the wellbaby clinic. After failing the first test, children were screened a second time one month later, and again one month later after failing the second test. Children were referred to their general practitioner (GP) upon either failing the CAPAS three times or failing twice, combined with other problems warranting referral, for example developmental problems or suspected severe hearing loss. Referral (i.e. failing CAPAS repeatedly) is taken here as marking persistent hearing loss.

Information about infants failing the screen with a permanent conductive or a sensorineural hearing loss was provided by the regional audiology centre. Here a specialised multidisciplinary team assessed the infants with a chronic hearing loss using voluntary response (visual re-enforcement audiometry) and fully objective tests (Auditory Brainstem Response, Auditory Steady State Response, tympanometry) and provided rehabilitation when needed. Children with such permanent impairments were excluded from our database, leaving the cases with OM-related hearing loss.

\section{Study protocol}

Parents of all children born between 1-6-2004 and 31-12-2004 in the province of Limburg, the Netherlands, received the routine CAPAS invitation, along with information regarding this study, a consent form and the PEPPER questionnaire, which the parents were asked to complete and bring to the well baby clinic at the screening visit. The results of the 
questionnaire were not shared with the well-baby clinic doctors and therefore it did not influence routine practice at the well-baby clinic. Questionnaires were scanned into an SPSS file (Statistical Package for the Social Sciences; version 15.0), checked and merged with the CAPAS data. Excluded from the study database were children with sensorineural hearing loss or permanent conductive hearing loss and children with Down syndrome and cleft palate or other cranio-facial malformations.

\section{Statistical analysis}

Univariate logistic regression, using SPSS version 15.0, was applied to determine factors predicting referral. Response categories of some PEPPER items were combined when category counts were extremely small, as noted in Appendix A. The items 'number of children in day care' and 'breastfeeding' were dichotomised into 'attending day care with $>4$ children' and 'at least 3 months exclusive breastfeeding' to facilitate comparison with earlier studies ${ }^{17-22}$. 'Early birth' means gestational age <37 weeks.

\section{Comparison with other studies}

A literature search using the terms 'otitis media', 'risk factors' and 'infants' resulted in a set of studies of risk factors for OM. Studies based on consultation rather than screening, that included children over 2 years, or studies with acute otitis media (AOM) or otorrhoea as outcome variable were excluded and only studies in developed countries were included. The search failed to find any study specifically on risk factors for the hearing loss related to OME at this age, but did yield 8 studies on multiple risk factors for $\mathrm{OM}^{17-25}$.

\section{RESULTS AND STUDY COMPARISON}

The response rate was 56.4\% (6531 questionnaires sent, 3681 completed, $50.1 \%$ boys, $49.8 \%$ girls). Only 13 cases did not complete the questionnaire prior to the screen according to protocol, and leaving these cases out of the analysis did not change the results. Mean age at completion was 9 months 6 days (range 6 months 18 days to 16 months 9 days) and first CAPAS 
screening 9 months 24 days (range 7 months 21 days to 13 months 24 days). See Figure 1.

Figure 1 Number of children invited for the hearing screen and response rates for the PEPPER questionnaire and hearing screen.

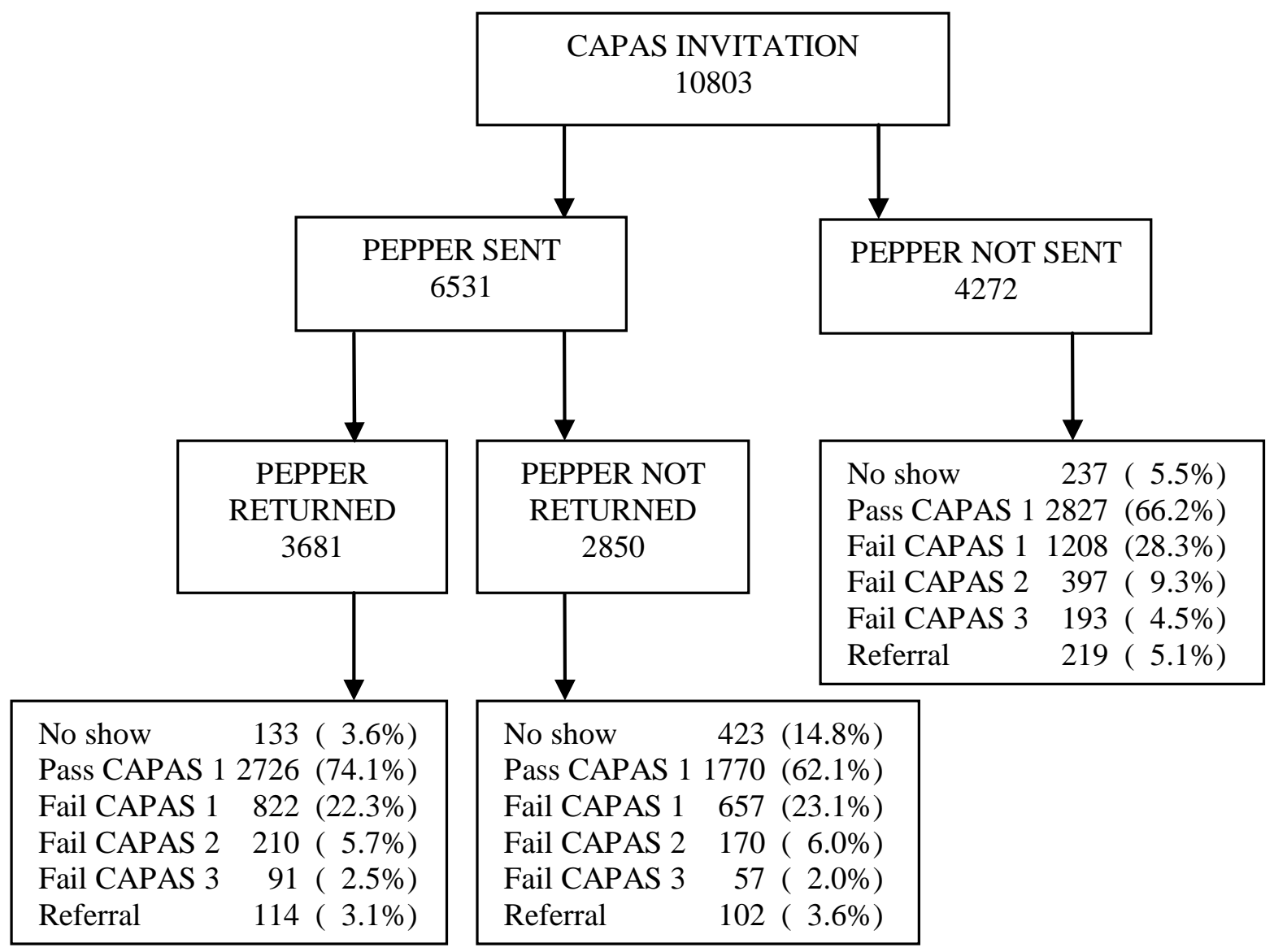

In Table 1 ORs and 95\% CI are presented for each item. Question 1 and the category 'other' from questions 2, 3 and 4 were dropped because of inconsistent interpretation and irrelevant responses

Four highly significant $(\mathrm{p}<0.001)$ risk factors were found: 'having severe cold symptoms', 'attending day care with $>4$ children', 'having siblings' and 'male gender'. Risk factors significant for referral with a p-value of $<0.01$ were 'severe nasal congestion', 'siblings with a history of ear/hearing problems' and 'father working part time'. However, when the factor 
'siblings with a history of ear/hearing problems' $(\mathrm{p}=0.003)$ was adjusted for 'having siblings', this item became non-significant ( $\mathrm{OR}=1.2 ; \mathrm{p}=0.44)$.

'Breastfeeding for at least 3 months' had a paradoxical 1.5 higher odds $(\mathrm{p}=0.01)$, rather than being protective for referral. 'Season of CAPAS' being January-March or July-September had increased odds for referral with a $\mathrm{p}=0.05$. However the CAPAS screen is no longer in use and therefore this factor will be irrelevant in the future

\section{COMPARISON WITH OTHER STUDIES}

To aid comparison, the results of the reference studies investigating more than one risk factor are also summarised in Table 1 and mentioned here, leaving wider interpretation to the Discussion section. There are two reports from one single study ${ }^{192}$. One study ${ }^{21}$ provided only ORs without statistical significance levels and another ${ }^{23}$ is not included in the table as ORs were not given at all. Although populations can differ and some risk factors may be more specific for hearing loss rather than for OM, the large sample size makes the present study more powerful than others with fewer false-positive findings for expected trends.

\section{Classical risk factors}

\section{Siblings}

'Having siblings' is a risk factor, consistent with the reference studies ${ }^{17-22}$, although our estimate is greater in magnitude. Risk probably increases with more siblings, as reported elsewhere ${ }^{21}$, but we were unable to test this with our data.

\section{Day care}

'Attending day care' was a risk factor in five of the comparison studies ${ }^{18,20-}$ ${ }^{22,24}$ but not in ours. We did find increased odds with 'attending day care with $>4$ children' $(\mathrm{OR}=1.9 ; \mathrm{p}<0.001)$ indicating that it is indeed the number of children an infant is exposed to which is relevant ${ }^{4}$.

\section{Gender}

Boys have almost twice the odds for developing OM-related hearing loss $(\mathrm{OR}=1.9 ; \mathrm{p}<0.001)$ and this agrees with one other included study ${ }^{24}$ as well 
as with the general background of literature on OM. One study ${ }^{22}$ showed a marginal trend $(\mathrm{OR}=1.5 ; \mathrm{p}=0.055)$ and another ${ }^{21}$ reported an increased risk without specifying significance. Overall, boys are at raised risk for $\mathrm{OM}^{4}$ 24,26 .

\section{Genetic disposition}

'Siblings with a history of ear/hearing problems' emerged as a risk factor $(\mathrm{OR}=1.7 ; \mathrm{p}=0.003)$, consistent with one previous study ${ }^{22}$. However, upon adjustment for 'having siblings' this risk decreased and was no longer significant. It seems that 'having siblings', an environmental risk factor, is a stronger risk factor than genetic disposition. Having 'parents with a history of ear/hearing problems' was not a risk either.

\section{Parents' working status}

'Father working part time' had significantly higher odds $(\mathrm{OR}=2.0 ; \mathrm{p}=0.007)$ while mother's working status appeared to be unrelated to referral. There were no studies for comparison.

\section{Breast feeding}

'Breastfeeding' emerged as an apparent risk rather than a protective factor. One reference study ${ }^{23}$ reported breastfeeding as protective, while six other studies ${ }^{17-22,25}$ were unable to do so. One ${ }^{22}$ did report that the longer a child was breastfed, the less the risk for developing OM. Varying definitions of breastfeeding or the absence thereof make comparison difficult ( $>7$ months of breastfeeding ${ }^{22}$; exclusive breastfeeding for 6 months ${ }^{25}$, exclusive breastfeeding for $>4$ months ${ }^{17,22}$; median of 2 months breastfeeding ${ }^{18}$; at least 6 months breastfeeding ${ }^{19,20}$; no definition ${ }^{21,23,24}$ ).

\section{Upper respiratory tract infection symptoms (URTI)}

Mouth breathing, snoring and nasal congestion can all be symptoms of URTI and can be related to adenoid hypertrophy. These factors could therefore impose a risk for developing OM and OM-related hearing loss. Neither 'severe mouth breathing' nor 'severe snoring' appeared to be risks here or in another study ${ }^{18}$.

'Severe nasal congestion' appeared as a risk here $(\mathrm{OR}=1.8 ; \mathrm{p}=0.006)$, and in one reference study ${ }^{25}$ which showed that the risk increased with growing number of days with nasal congestion. 'Severe cold symptoms' $(\mathrm{OR}=1.9$; $\mathrm{p}<0.001$, which is less specific, embracing coughing, common cold 
symptoms and sore throat, was also significant in all four studies reporting on it ${ }^{18-21,23}$.

The understanding of 'severe cold symptoms' as well as 'severe nasal congestion' probably varies much amongst parents and might be rather imprecise. Although we are obviously not dealing with a homogenous group, the results show that these items do predict referral and therefore they can be of interest.

\section{Ear and hearing problems}

Having had a history of hearing problems ${ }^{18}$, ear infections ${ }^{18,21,24,25}$ or early $\mathrm{OME}^{23}$ or early otitis ${ }^{25}$ have all been reported as a risk for developing chronic OM. However, they were not related to hearing in our study, nor in one other study ${ }^{19,20}$. Our study population was very young, making it difficult for their parents to detect hearing loss or ear infections and this could have influenced the results.

\section{Smoking}

Smoking around the child by household members did not appear to be a risk factor nor did the number of cigarettes smoked inside the house. This is in line with the results of several recently completed studies ${ }^{18-23}$. However, one of the reference studies ${ }^{17}$ found that smoking 10-19 cigarettes per day was a risk, although smoking > 20 was not. Another study ${ }^{25}$ found that the number of smokers around the child did increase the risk of persistent OM, although in that study the number of cigarettes smoked was not a significant risk. We did not ask about smoking habits around the child outside the house, and therefore the results may be an underestimation.

\section{Season}

$\mathrm{OM}$ is least prevalent in summer ${ }^{3,5,22}$ and $\mathrm{OM}$ first detected in fall and winter has a greater tendency to persist ${ }^{6}$. Two reference studies ${ }^{17} 18$ confirmed this classical effect. We did not find season to be a risk factor when considering the four traditional seasons. However, when October through March were compared to April through September, we did find a 1.5 higher odds for referral $(\mathrm{p}=0.065)$, which was in concordance with two other studies ${ }^{22,24}$. 
Table 1 Questions in the PEPPER item pool and results found in the literature for the

\begin{tabular}{|c|c|c|c|}
\hline & $\begin{array}{l}\text { Lok } \\
\text { OR }(95 \% \text { CI })\end{array}$ & $\begin{array}{l}\text { Dewey }{ }^{17} \\
\text { OR }(95 \% C I)\end{array}$ & $\begin{array}{l}\text { Engel }^{18} \\
\text { OR }(95 \% \mathrm{CI})\end{array}$ \\
\hline Q3: Delay in growth $\sim$ Low birth weight & $1.1(0.3-4.5)$ & $1.3(1.0-1.6)^{*}$ & $\# * *$ \\
\hline Q3: Early birth: (<37 weeks) & $1.0(0.5-1.9)$ & \# & $\# *$ \\
\hline Q4: Meconium stained amniotic fluid & $0.9(0.5-1.4)$ & & \\
\hline \multicolumn{4}{|l|}{ Q5: Age of first ear infection } \\
\hline $0-5$ months & $0.7(0.3-1.6)$ & & \\
\hline 6-9 months & $1.0(0.6-1.8)$ & & \\
\hline 0-9 months $\sim$ History of an ear infection & $0.9(0.6-1.4)$ & & $1.8(1.3-2.6)^{* * *}$ \\
\hline \multicolumn{4}{|l|}{ Q6: Age of first hearing problem } \\
\hline $0-5$ months & $0.9(0.2-3.8)$ & & \\
\hline 6-9 months & $0.6(0.1-4.0)$ & & \\
\hline $\begin{array}{l}0-9 \text { months } \sim \text { History of an hearing } \\
\text { problem }\end{array}$ & $0.7(0.2-2.4)$ & & $1.7(1.0-2.7)^{*}$ \\
\hline Q7: An ear infection in last 3 months & $1.2(0.8-1.8)$ & & \\
\hline Q8: An ear infection in last month & $1.3(0.8-2.3)$ & & \\
\hline Q9a: Mouth breathing & $1.4(0.8-2.3)$ & & $1.3(1.0-1.6)^{*}$ \\
\hline Q9b: Nasal congestion & $1.8(1.2-2.8)^{* *}$ & & \\
\hline Q9c: Snoring & $1.3(0.8-2.3)$ & & $1.1(0.9-1.4)$ \\
\hline Q9d: Cold symptoms URTI & $1.9(1.3-2.7)^{* * *}$ & & $1.6(1.2-2.0)^{* * *}$ \\
\hline Q10: Smoking around child & $1.0(0.6-1.6)$ & & \\
\hline \multicolumn{4}{|l|}{ Q11: Number of cigarettes smoked } \\
\hline $0-20$ & $1.1(0.7-1.7)$ & & \\
\hline $10-19$ & & $1.6(1.1-2.3)^{*}$ & \\
\hline$>20$ & $1.3(0.4-4.2)$ & $0.8(0.5-1.3)$ & \\
\hline \multicolumn{4}{|l|}{$\begin{array}{l}\text { Q12: Heating of the house (reference }= \\
\text { central heating) }\end{array}$} \\
\hline Stove & $0.6(0.1-4.5)$ & & \\
\hline Central heating and also a stove & $1.1(0.7-1.8)$ & & \\
\hline Q13: Breastfeeding & $1.5(1.1-2.1)^{*}$ & \# & $1.1(0.8-1.6)$ \\
\hline \multicolumn{4}{|l|}{ Q14: Sleeping habit (reference $=$ back) } \\
\hline Side & $1.1(0.7-1.8)$ & & \\
\hline Stomach & $1.2(0.8-1.8)$ & & \\
\hline Q15a: Sucking is weak & $1.2(0.5-2.7)$ & & \\
\hline Q15b: Slow-to-feed & $1.6(0.9-2.9)$ & & \\
\hline Q16: Day care & $1.4(1.0-1.9)$ & & $1.6(1.1-2.2)^{* *}$ \\
\hline Number of children attending: $>4$ & $1.9(1.3-2.7)^{* * *}$ & $1.4(1.0-1.8)^{*}$ & \\
\hline Q17: Having siblings & $2.8(1.9-4.1)^{* * *}$ & $1.5(1.2-1.9)^{*}$ & \\
\hline More than one compared to one & & & $1.5(1.2-2.0)^{*}$ \\
\hline Q18: Family history of ear/hearing problems & $1.0(0.7-1.4)$ & & $0.8(0.6-1.0)$ \\
\hline Siblings with a history of OME & $1.7(1.2-2.5)^{* *}$ & & \\
\hline \multicolumn{4}{|l|}{ Q19: Father working (reference $=$ full time) } \\
\hline Part time & $2.0(1.2-3.3)^{* *}$ & & \\
\hline Not working & $0.8(0.4-1.5)$ & & \\
\hline \multicolumn{4}{|l|}{$\begin{array}{l}\text { Q20: Mother working (reference }=\text { not } \\
\text { working) }\end{array}$} \\
\hline Part time & $1.2(0.9-1.8)$ & & \\
\hline Full time & $1.3(0.6-3.1)$ & & \\
\hline Gender $=$ male & $1.9(1.3-2.7)^{* * *}$ & & $1.0(0.8-1.3)$ \\
\hline
\end{tabular}

$* * *$ p-value $<0.001 ; * *$ p-value $<0.01 ; *$ p-value $<0.05$

\#The risk factor is mentioned in the article without specifying the RR or OR, or the risk factor is 
corresponding risk factors for $\mathrm{OM}$

\begin{tabular}{lllll}
\hline $\begin{array}{l}\text { Rovers } \\
\text { OR }(95 \% \text { CI })\end{array}$ & $\begin{array}{l}\text { Sassen }^{21} \\
\text { OR }\end{array}$ & $\begin{array}{l}\text { Zielhuis }^{22} \\
\text { OR }(\mathbf{p})\end{array}$ & $\begin{array}{l}\text { Alho }^{24} \\
\text { OR (95\% CI })\end{array}$ & $\begin{array}{l}\text { Kraemer }^{25} \\
\text { OR (95\% CI) }\end{array}$ \\
\hline $0.4(0.2-0.9)$ & & $1.61(0.190)$ & & $1.3(0.3-5.0)$ \\
$0.5(0.3-1.1)$ & & $\# 0.74(0.354)$ & & \\
& & & & \\
\hline
\end{tabular}

$3.0(1.2-7.4)$

$1.3(0.9-1.8) \quad 2.12$

\#

$3.7(1.2-11.2)$

\#

\begin{tabular}{|c|c|c|c|}
\hline $2.6(2.0-3.6)$ & 1.46 & & \\
\hline $1.0(0.7-1.4)$ & 0.95 & $1.11(0.643)$ & \# \\
\hline
\end{tabular}

$1.0(0.7-1.4)$

\begin{tabular}{llll}
\hline $1.1(0.8-1.5)$ & 0.98 & $\# 0.71(0.187)$ & $1.1(0.5-2.7)$
\end{tabular}

\begin{tabular}{lllll}
\hline $1.9(1.3-2.6)$ & 1.67 & $1.88(0.007)$ & $2.6(1.2-5.6)^{*}$ & \\
$3.2(2.3-4.4)$ & $1.97-5.60$ & $\#(0.010)$ & $1.8(0.96-3.3)$ & $0.6(0.3-1.3)$ \\
& & & & $1.9(0.9-3.6)$ \\
\hline
\end{tabular}

$\begin{array}{llll}1.4(1.0-1.8) & 1.24 & 1.50(0.055) & 2.2(1.4-3.4)^{*}\end{array}$

not exactly the same and cannot be added to the table . 
Table 1 Questions in the PEPPER item pool and results found in the literature for the

\begin{tabular}{|c|c|c|c|}
\hline & $\begin{array}{l}\text { Lok } \\
\text { OR (95\% CI) }\end{array}$ & $\begin{array}{l}\text { Dewey }{ }^{17} \\
\text { OR }(95 \% \mathrm{CI})\end{array}$ & $\begin{array}{l}\text { Engel }{ }^{18} \\
\text { OR }(95 \% \mathrm{CI})\end{array}$ \\
\hline \multicolumn{4}{|c|}{ Season (reference $=$ October-December) } \\
\hline January-March & \# & $1.7(1.4-2.1)^{*}$ & \\
\hline April-June & \# & $1.0(0.8-1.2)$ & \\
\hline July-September & \# & $0.5(0.4-0.6)^{*}$ & \\
\hline
\end{tabular}

\section{Less conventional risk factors}

\section{Prenatal and birth characteristics}

Low birth weight was not defined uniformly, hindering comparison $(<2500 \mathrm{~g}$ ${ }^{19,22,25} ;<3100 \mathrm{~g}^{17} ;<3400 \mathrm{~g}^{18}$ ). We used the less specific term 'delay in growth' as a marker for low birth weight. It did not appear to be a risk factor. Two reference studies ${ }^{17,18}$ found low birth weight to be a risk factor, two did not $^{22,25}$, and one ${ }^{19}$ even found low birth weight to be protective.

Prematurity is usually defined as a gestational age $<37$ weeks ${ }^{17,19,20}$, although $<38$ weeks has also been used ${ }^{22}$. One study ${ }^{18}$ analysed prematurity appropriately as a continuous measure, finding all children born before a gestational age of 40 weeks having an increased risk for OM, this risk being greater the more premature the birth was. None of the other studies, including ours, found prematurity to be a risk factor.

'Meconium stained amniotic fluid' has been studied as a risk in developing $\mathrm{OM}$, using varying definitions and subsequently finding conflicting results ${ }^{27-29}$. Overall, these studies, including ours, did not find the mere presence of meconium stained amniotic fluid to be a risk ${ }^{27,29}$. A recent study ${ }^{28}$ using the stringent definition of meconium stained amniotic fluid being present at birth with pulmonary aspiration requiring tracheal suction and treatment at a neonatal intensive care unit, did find an increased risk for AOM. That study mentioned that the mechanism is obscure but presumably related to immune immaturity, although it might also be related to treatment.

\section{Sucking and eating}

The items 'sucking is weak' and 'slow-to-feed' could be seen as symptoms of nasal congestion and/or adenoid hypertrophy, being proxies for mouthbreathing, but more appropriate questions to ask in the child under 6 months. 
corresponding risk factors for $\mathrm{OM}$

\begin{tabular}{lllll}
\hline Rovers $^{1920}$ & Sassen $^{21}$ & Zielhuis $^{22}$ & Alho $^{24}$ & Kraemer $^{25}$ \\
OR (95\% CI) & OR & OR (p) & OR (95\%CI) & OR (95\% CI) \\
\hline & & & & \\
& & $\#$ & $\#$ & \\
& $\#$ & $\#$ & \\
& $\#$ & $\#$ & \\
\hline
\end{tabular}

not exactly the same and cannot be added to the table.

These items were not predictive overall for referral and there were no studies for comparison.

\section{Sleeping position}

Sleeping in the prone position has been reported as an increased risk for coughing, ear ache and hearing problems in the young infant ${ }^{30}$ or for 'having ear infections' and developing a 'stuffy nose at 6 months of age' ${ }^{31}$. In our study however, it may not have emerged as a risk as the number of children sleeping prone was too few to detect a difference at statistical significance.

\section{Heating of the house}

We found no studies on 'heating of the house', which could reflect socioeconomic status, general environmental stress or indoor air quality. The effect of using secondary home heating sources (a fire place, wood-burning stove, kerosene heater or a gas stove) has been studied before in developing $\mathrm{AOM}^{32}$. Neither in that study nor in ours was a significant association found. Although indoor air quality does seem to affect URTI ${ }^{33}$ and hence possibly OM, the absence of central heating in the Netherlands is too rare to detect any such an effect.

\section{GENERAL DISCUSSION}

Researchers as well as clinicians know that there are children with persistent OM-related hearing loss who might benefit from treatment ${ }^{34,35}$. For example, one study ${ }^{36}$ showed that with every $\mathrm{dB}$ improvement in hearing, the comprehensive language development improved with 0.05 month. Identifying these children is however difficult and screening for hearing loss in a healthy population and subsequent treatment with tubes is not effective 
34,35. The increase in number of very young children treated with tubes in the Netherlands ${ }^{16}$ may reflect clinical uncertainty and consequent overtreatment. It shows the need for more selective case-finding. Risk factor studies in OM have not used OM-related hearing loss as the outcome, although hearing loss resulting from OM should be a major concern, as it is the presumed route to developmental delays, so justifying parental concern and medical attention. This serious omission is met by our study.

In the present study, we cannot distinguish between general factors leading to non-persistent $\mathrm{OM}$ and specific factors leading on to persistent $\mathrm{OM}$ and/or on to subsequent OM-related hearing loss. However, it is reasonable to assume that the overlap is substantial, allowing us to compare our findings with those for OM ${ }^{17-25}$. The results of our study do, to some extent, differ from the results of the studies used for comparison, but no more than those studies' results differ from each other so the former contrast should not be overplayed. Differences in the reference group used and how the potential risk factors have been operationalised will clearly affect the magnitude of ORs, while sample size will affect the statistical significance. Furthermore, differing results may reflect varying exposure to risk factors between populations ${ }^{37}$ and international or policy differences in care seeking for ear problems ${ }^{38}$.

The historical opportunity form the change in system places our results in 2004; extrapolating these results to the present day should be done with some caution as some of the studied items are not proximate risks for developing OM-related hearing loss, instead for example social conditions (work, socioeconomic status) are mere proxies for underlying risks. These social conditions can change over time; however to our knowledge, no such major change has been recorded.

\section{Conflicting or surprising findings}

Our study did not find parent-reported ear infections to predict referral. As some OM history is fairly common, the inconsistency here may be due to whether the controls are disease free or at least unselected, and the difficulty in capturing strength of history in a still young infant.

The risk of having 'siblings with a history of ear/hearing problems' decreased after adjustment for 'having siblings' and was no longer 
significant. We assume that the risk of having 'siblings with a history of ear/hearing problems' is not a marker of genetic disposition, but rather a marker for shared environmental risk factors. This explains why the risk diminished when adjusting for 'having siblings'.

The fact that breastfeeding appeared to be a risk rather than a protection might seem surprising. Perhaps the protective effect of breastfeeding is small, short lasting or hard to capture, as children could be (partly) switched to bottle feeding at some time. Another explanation may be that breastfeeding and referral are both associated with the socioeconomic status of the parents. More highly educated parents usually extend the period of breastfeeding ${ }^{39,40}$ and higher SES is associated with greater uptake of health care $^{41}$. A child could therefore be breastfed for a longer period of time, but also be referred despite having fewer or milder problems because of parental concern expressed at the well-baby clinic, as there is room for such individual concern in the referral process. Selection bias may also play a role here, as parents who breastfeed may also be more likely to have concerns about their child's ear status and to return questionnaires. Furthermore, we are studying OM without signs of an acute infection. A recent study investigating the risks of formula feeding did find a protective effect of breastfeeding against developing acute $\mathrm{OM}^{42}$. Together, these considerations could explain the marginal inverse effect found here and some of the inconsistencies in findings on breastfeeding generally.

The items on parents' working status were included to capture socioeconomic status. The increased risk with a father working part time is puzzling, possibly a random finding or an obscure socioeconomic marker in this population. If this item is included in future studies for replication, it would be useful to ascertain the type of work the father does, the reasons for working part time, and the number of hours worked per week.

Home air quality deserves consideration alongside smoking, although both have become difficult to study with changes in standard of living and lifestyle, perhaps contributing to null results. Our study only showed a trend in the number of cigarettes smoked in the house whilst reported smoking around the child was not statistically significant at all. Results on consumption of addictive substances are known to be distorted by a social desirability bias in reporting known or believed risk factors under some 
degree of voluntary control. A study with an objective marker of exposure to smoking did find an accompanying risk for $\mathrm{OM}$ and recurrent $\mathrm{OM}^{43}$.

Eight items were found to be associated with a higher risk of referral after failing the hearing screen. The results of both the items 'breastfeeding' and 'father working part time' were puzzling. Furthermore, 'siblings with a history of ear/hearing problems' became non-significant when it was adjusted for 'having siblings'. Therefore five reliable risk factors, consistent with past literature, are simply predictive for referral: 'having severe cold symptoms', 'attending day care with $>4$ children', 'having siblings', 'severe nasal congestion' and 'male gender'.

\section{Study limitations}

\section{Response rate}

Our response rate was $56.4 \%$, which although reasonable for a service-based population study ${ }^{44}$ invites replication in other studies using perhaps fewer items. Response rates do not necessarily influence which items are found to be predictive although they obviously influence statistical reliability, and can influence the OR of a specific item ${ }^{45}$. To determine any participation bias, we compared the responders to the non-responders. Fewer children of responders failed to show up at the first hearing screen compared to nonresponders (3.6\% versus 14.8\%, see Figure 1). As the PEPPER questionnaire should have been completed and brought to the well-baby clinic during the first testing, we received fewer questionnaires from the group not attending the hearing screen. Furthermore, the non-responders lived in areas with relatively higher percentage migrant population, more unemployment and lower incomes, all of which co-indicate a lower SES and this could explain the non-responding ${ }^{46}$. At the same time, there appears to be no real bias in referral. Slightly fewer children from responders were referred compared to non-responders ( $3.1 \%$ versus $3.6 \%$, not statistically significant different). Thus, we appear to be reporting on a sub-population with a high participation rate both in research and routine service, but without difference in outcome measurement. 


\section{Individual outcomes from the screen}

Precise reasons for screen failure are unknown in individual cases. However, most infants who repeatedly fail a distraction hearing screen have conductive hearing loss due to OM ${ }^{15,47,48}$. A previous study ${ }^{15}$ reported that $58 \%$ of the children failing the CAPAS and referred to an ENT department were diagnosed with bilateral OME and 70\% with bilateral or unilateral OME, as confirmed by otoscopy and tympanometry at the ENT department. There was a delay between the hearing screen and the diagnosis at the ENT department and although this was not long ( 0.8 months) it could however have led to an underestimation of the percentage of children with bilateral $\mathrm{OME}$ at the time of referral. The time for spontaneous resolution varies, but can be $11-40 \%$ in 4-6 weeks depending on criteria used ${ }^{1,3,6}$. The percentage of children with bilateral OME at the time of referral was probably higher than the reported 58\%. We therefore assume that most hearing screen fails are indicative of persistent OM-related hearing loss.

The present study is cross-sectional and thus precludes capturing all children who may be prone to long-persisting OM with accompanying hearing loss. Obviously, children may develop OM-related hearing loss after passing the hearing screen due to OM being a seasonally fluctuating condition. Such children will have entered the control group. This will not necessarily distort the profile of risk factors, but it will reduce sensitivity.

\section{Implications for future research}

The present results are encouraging for low-cost questionnaire-based screening. Future research should focus on creating a practical short casefinding instrument for persistent OM-related hearing loss. The PEPPER questionnaire can be completed by the child's parents or guardians within 3 minutes. However, processing the data from even a short questionnaire requires staff time and facilities. We do not yet feel justified in recommending the five selected items as a short form for immediate use with simple equal-weight scoring.

Multi-variable modelling can reveal optimal combinations of risk factor items and optimal scaling of item response levels. An optimum scoring algorithm based on such an item selection then needs to be evaluated and the predictive value should be tested again, thereby verifying the optimum 
scoring. At the same time issues of practical implementation should be addressed, where after routine implementation can be organised.

\section{CONCLUSIONS}

Five reliable items, consistent with the reviewed literature, are associated with a higher risk of referral after failing the hearing screen: 'having severe cold symptoms', 'attending day care with >4 children', 'having siblings', 'severe nasal congestion' and 'male gender'. Combinations of these factors via multi-variable models might be worth optimising to see whether a casefinding instrument for routine referral of young children with chronic OMrelated hearing loss can be developed. 


\section{REFERENCES}

1. Alho OP, Oja H, Koivu M, Sorri M. Chronic otitis media with effusion in infancy. How frequent is it? How does it develop? Arch Otolaryngol Head Neck Surg 1995;121:432-436.

2. Engel J, Anteunis L, Volovics A, Hendriks J, Marres E. Prevalence rates of otitis media with effusion from 0 to 2 years of age: healthy-born versus highrisk-born infants. Int J Pediatr Otorhinolaryngol 1999;47:243-251.

3. Midgley EJ, Dewey C, Pryce K, Maw AR. The frequency of otitis media with effusion in British pre-school children: a guide for treatment. ALSPAC Study Team. Clin Otolaryngol Allied Sci 2000;25:485-491.

4. Paradise JL, Rockette HE, Colborn DK et al. Otitis media in 2253 Pittsburgharea infants: prevalence and risk factors during the first two years of life. Pediatrics 1997;99:318-333.

5. Zielhuis GA, Rach GH, Van den Broek P. The occurrence of otitis media with effusion in Dutch pre-school children. Clin Otolaryngol Allied Sci 1990;15:147-153.

6. Rosenfeld RM, Kay D. Natural history of untreated otitis media. Laryngoscope 2003;113:1645-1657.

7. Fria TJ, Cantekin EI, Eichler JA. Hearing acuity of children with otitis media with effusion. Arch Otolaryngol 1985;111:10-16.

8. Anteunis LJ, Engel JA, Hendriks JJ, Volovics A, Chenault MN, Manni J.J. Otitis media with effusion-algorithms and the associated hearing loss in infants 0-2.: Maastricht University Medical Centre, 2000:141-154.

9. Anteunis LJ, Engel JA, Hendriks JJ, Manni JJ. A longitudinal study of the validity of parental reporting in the detection of otitis media and related hearing impairment in infancy. Audiology 1999;38:75-82.

10. Rosenfeld RM, Goldsmith AJ, Madell JR. How accurate is parent rating of hearing for children with otitis media? Arch Otolaryngol Head Neck Surg 1998;124:989-992.

11. Stewart MG, Ohlms LA, Friedman EM et al. Is parental perception an accurate predictor of childhood hearing loss? A prospective study. Otolaryngol Head Neck Surg 1999;120:340-344.

12. Bennett KE, Haggard MP, Silva PA, Stewart IA. Behaviour and developmental effects of otitis media with effusion into the teens. Arch Dis Child 2001;85:91-95.

13. Brouwer CN, Maille AR, Rovers MM, Grobbee DE, Sanders EA, Schilder AG. Health-related quality of life in children with otitis media. Int J Pediatr Otorhinolaryngol 2005;69:1031-1041.

14. Lous J, Burton MJ, Felding JU, Ovesen T, Rovers MM, Williamson I. Grommets (ventilation tubes) for hearing loss associated with otitis media with effusion in children. Cochrane Database Syst Rev 2005:CD001801.

15. Rovers MM, Zielhuis GA, Straatman H, Ingels K, van der Wilt GJ, Kauffmande Boer M. Comparison of the CAPAS and Ewing tests for screening of hearing in infants. J Med Screen 1999;6:188-192.

16. Lok W, Chenault MN, Anteunis LJ. Implementation of neonatal screening for hearing impairment: influence on pediatric otitis media surgery in The Netherlands. Int J Pediatr Otorhinolaryngol 2009;73:1090-1094. 
17. Dewey C, Midgeley E, Maw R. The relationship between otitis media with effusion and contact with other children in a British cohort studied from 8 months to 3 1/2 years. The ALSPAC Study Team. Avon Longitudinal Study of Pregnancy and Childhood. Int J Pediatr Otorhinolaryngol 2000;55:33-45.

18. Engel J, Anteunis L, Volovics A, Hendriks J, Marres E. Risk factors of otitis media with effusion during infancy. Int J Pediatr Otorhinolaryngol 1999;48:239-249.

19. Rovers MM, Hofstad EA, Franken-van den Brand KI et al. Prognostic factors for otitis media with effusion in infants. Clin Otolaryngol Allied Sci 1998;23:543-546.

20. Rovers MM, Zielhuis GA, Straatman H, Ingels K, van der Wilt GJ, van den Broek P. Prognostic factors for persistent otitis media with effusion in infants. Arch Otolaryngol Head Neck Surg 1999;125:1203-1207.

21. Sassen ML, Brand H, Grote JJ. Risk factors for otitis media with effusion in children 0 to 2 years of age. Am J Otolaryngol 1997;18:324-330.

22. Zielhuis GA, Heuvelmans-Heinen EW, Rach GH, van den Broek P. Environmental risk factors for otitis media with effusion in preschool children. Scand J Prim Health Care 1989;7:33-38.

23. Gliddon ML, Sutton GJ. Prediction of 8-month MEE from neonatal risk factors and test results in SCBU and full-term babies. Br J Audiol 2001;35:77-85.

24. Alho OP, Oja H, Koivu M, Sorri M. Risk factors for chronic otitis media with effusion in infancy. Each acute otitis media episode induces a high but transient risk. Arch Otolaryngol Head Neck Surg 1995;121:839-843.

25. Kraemer MJ, Richardson MA, Weiss NS et al. Risk factors for persistent middle-ear effusions. Otitis media, catarrh, cigarette smoke exposure, and atopy. JAMA 1983;249:1022-1025.

26. Daly KA, Rovers MM, Hoffman HJ et al. Recent advances in otitis media. 1. Epidemiology, natural history, and risk factors. Ann Otol Rhinol Laryngol Suppl 2005;194:8-15.

27. Jaber L, Gabriel R, Merlob P. Meconium aspiration and otitis media in children. Eur J Pediatr 1993;152:164-165.

28. Lilja M, Palva T, Ramsay H, Laitinen K, Andersson S. Meconium contaminated amniotic fluid and infant otitis media. Is it a risk factor in children surviving aspiration and initial distress of respiration? Int J Pediatr Otorhinolaryngol 2006;70:655-662.

29. Straetemans M, Schonbeck Y, Engel JA, Zielhuis GA. Meconium-stained amniotic fluid is not a risk factor for otitis media. Eur Arch Otorhinolaryngol 2003;260:432-435.

30. Hunt L, Fleming P, Golding J. Does the supine sleeping position have any adverse effects on the child? I. Health in the first six months. The ALSPAC Study Team. Pediatrics 1997;100:E11.

31. Hunt CE, Lesko SM, Vezina RM et al. Infant sleep position and associated health outcomes. Arch Pediatr Adolesc Med 2003;157:469-474.

32. Pettigrew MM, Gent JF, Triche EW, Belanger KD, Bracken MB, Leaderer BP. Infant otitis media and the use of secondary heating sources. Epidemiology 2004;15:13-20. 
33. Volkmer RE, Ruffin RE, Wigg NR, Davies N. The prevalence of respiratory symptoms in South Australian preschool children. II. Factors associated with indoor air quality. J Paediatr Child Health 1995;31:116-120.

34. Butler CC, van der Linden MK, MacMillan H, van der Wouden JC. Screening children in the first four years of life to undergo early treatment for otitis media with effusion. Cochrane Database Syst Rev 2003:CD004163.

35. Simpson SA, Thomas CL, van der Linden MK, Macmillan H, van der Wouden JC, Butler C. Identification of children in the first four years of life for early treatment for otitis media with effusion. Cochrane Database Syst Rev 2007:CD004163.

36. Rovers MM, Straatman H, Ingels K, van der Wilt GJ, van den Broek P, Zielhuis GA. The effect of ventilation tubes on language development in infants with otitis media with effusion: A randomized trial. Pediatrics 2000;106:E42.

37. Rovers MM, de Kok IM, Schilder AG. Risk factors for otitis media: an international perspective. Int J Pediatr Otorhinolaryngol 2006;70:1251-1256.

38. Froom J, Culpepper L, Green LA et al. A cross-national study of acute otitis media: risk factors, severity, and treatment at initial visit. Report from the International Primary Care Network (IPCN) and the Ambulatory Sentinel Practice Network (ASPN). J Am Board Fam Pract 2001;14:406-417.

39. Flacking R, Nyqvist KH, Ewald U. Effects of socioeconomic status on breastfeeding duration in mothers of preterm and term infants. Eur J Public Health 2007; 17:579-584.

40. Li R, Darling N, Maurice E, Barker L, Grummer-Strawn LM. Breastfeeding rates in the United States by characteristics of the child, mother, or family: the 2002 National Immunization Survey. Pediatrics 2005;115:e31-37.

41. Reijneveld SA. Reported health, lifestyles, and use of health care of first generation immigrants in The Netherlands: do socioeconomic factors explain their adverse position? J Epidemiol Community Health 1998;52:298-304.

42. McNiel ME, Labbok MH, Abrahams SW. What are the risks associated with formula feeding? A re-analysis and review. Birth;37:50-58.

43. Ilicali OC, Keles N, De er K, Sa un OF, Guldiken Y. Evaluation of the effect of passive smoking on otitis media in children by an objective method: urinary cotinine analysis. Laryngoscope 2001;111:163-167.

44. Eaker S, Bergstrom R, Bergstrom A, Adami HO, Nyren O. Response rate to mailed epidemiologic questionnaires: a population-based randomized trial of variations in design and mailing routines. Am J Epidemiol 1998;147:74-82.

45. Mealing NM, Banks E, Jorm LR, Steel DG, Clements MS, Rogers KD. Investigation of relative risk estimates from studies of the same population with contrasting response rates and designs. BMC Med Res Methodol;10:26.

46. Martikainen P, Laaksonen M, Piha K, Lallukka T. Does survey non-response bias the association between occupational social class and health? Scand J Public Health 2007;35:212-215.

47. Mott A, Emond A. What is the role of the distraction test of hearing? Arch Dis Child 1994;70:10-13. 
48. Rovers MM, Straatman H, Zielhuis GA, Ingels K, van der Wilt GJ. Seasonal variation in the prevalence of persistent otitis media with effusion in one-yearold infants. Paediatr Perinat Epidemiol 2000;14:268-274. 


\section{CHAPTER 6}

\section{Selecting infants with OM that need referral and further assessment: creating a case-finding instrument}

W. Lok, M.N. Chenault, L.J.C. Anteunis, C. Meesters, M.P. Haggard

International Journal of Pediatric Otorhinolaryngology 2011; 1301-1307 


\begin{abstract}
Introduction In the Netherlands, many children are surgically treated for OM. Recent publications question the need for surgical treatment in common uncomplicated OM, although there is certainly a subgroup of infants that do need further assessment and possible treatment. The present study explores the possibility of using known and presumed risk factors for $\mathrm{OM}$ as an instrument for selecting and routing an infant with OM to further care.
\end{abstract}

Methods Two questionnaires were used. A questionnaire embracing a wide range of OM-related factors was sent to 6531 children that were routinely invited for the hearing screen at nine months. In a second stage, a structured history questionnaire regarding ear and/or hearing problems, subsequent referral and/or treatment, was sent to all parents of children at age 21 months, responding to the first questionnaire. Univariate analysis was performed for identification of potential predictors for surgical treatment of $\mathrm{OM}$ for the whole sample as well as for 4 different subsets. Multivariable regression analysis with stepwise backward deletion was applied to arrive at a model for optimal prediction of tube insertion. A ROC (receiver operating characteristic) curve and the accompanying sensitivity and specificity values were analyzed to determine cut off values.

Results Univariate analysis found 10 items predicting surgical treatment for OM. Multivariable regression analysis resulted in a model with a ROC curve having an area of 0.801 and estimated coefficients for risk factors which were used to calculate an OM-score for each case.

Conclusion The developed scoring sheet, e.g. to be used in combination with physical examinations and/or tympanometry looks promising as a predictor for those children that might benefit from further assessment and eventually surgically treatment for OM. 


\section{INTRODUCTION}

Ear and/or hearing problems caused by otitis media (OM) are highly prevalent in infants ${ }^{1-4}$, with almost $80-90 \%$ of all children experiencing at least a single episode before the age of 1 year. These ear and/or hearing problems represent about $20 \%$ of all general practitioner (GP) visits in children 0-2 years of age in the Netherlands ${ }^{5}$. About $53 \%$ of these infants whose parents consult the GP will be referred to a specialist, mostly to an ENT specialist (78\%), and about $83 \%$ of the children referred to the ENT specialist will thereafter be treated surgically ${ }^{6}$. In spite of recent publications questioning the need for (surgical) treatment for uncomplicated $\mathrm{OM}^{7,8}$, the numbers of children treated surgically in the Netherlands remain high ${ }^{9}$. Persistent OM can result in hearing loss ${ }^{10,11}$ and subsequent developmental problems, such as speech and/or language delays. Furthermore, it can cause behaviour ${ }^{12}$ and/or balance problems ${ }^{13}$. Most affected children will have uncomplicated OM. However, a subgroup of infants with OM, at risk for longer term OM-related problems, need further assessment and possibly treatment. The children in scope are very young, and for this reason it is intrinsically challenging to determine the individual need for referral and further assessment in this age group. Up to 2002, children in the Netherlands were screened for hearing loss at the age of nine months primarily to find congenital permanent impairments. Instead, the predominant majority of the children repeatedly failing the hearing screen at nine months had OM-related hearing loss ${ }^{14-17}$ and of these, most then underwent surgical treatment. Therefore, the screen also functioned as a tool for identification and subsequent referral and treatment of persistent OM-related hearing loss. The screen at nine months has now been replaced by the neonatal screen and, unexpectedly, since then more children not less are treated surgically for $\mathrm{OM}$ ${ }^{9}$. Considering recent publications questioning the need for treatment in uncomplicated $\mathrm{OM}$, there might be a need for a case-finding instrument for infants, selecting those at risk for hearing and developmental problems. Such case-finding would have to be inexpensive and feasible for a primary care setting; it should assist the GP in selecting those infants with OM that need further assessment by an ENT specialist.

The present study examines whether known and presumed risk factor items for OM, combined in a questionnaire to be completed by parents, can be 
used to predict which children will be treated with ventilation tubes. Treatment with tubes, i.e. ear and/or hearing problems sufficient to warrant treatment, is taken as outcome measure in statistical modelling, and we thus explore the possibility of using a combination of risk factor items as an instrument for selecting and routing an infant with diagnosed or suspected $\mathrm{OM}$ to further care. The study population consists of a large number of otherwise healthy young infants from the general Dutch population that were invited for the routine hearing screen at age nine months.

\section{METHODS}

\section{Questionnaires}

PEPPER questionnaire for infants with an appointment for the hearing screen at age 9 months: The PEPPER item pool ('Persistent Ear Problems, Providing Evidence for Referral'), initially developed in the United Kingdom, embraces a wide range of OM-related factors in a single instrument for use in primary care, and can be completed by the child's parent or guardian within 3 minutes. To facilitate use, the items were pooled into the PEPPER questionnaire. The English version of this questionnaire (Appendix A) was translated into Dutch. Although standardisation is not an issue here, it was also translated back into English by an English native speaker, resulting in only minor shades of difference in wording.

Follow-up questionnaire at the age of 21 months: A structured history questionnaire, named Q21, comprised 12 questions about attending the hearing screen, referral subsequent to this hearing screen, visits to the GP because of suspected ear and/or hearing problems and subsequent referral to a specialist (ENT specialist, paediatrician, or audiology department etc.) and treatment by an ENT specialist. See Appendix B.

\section{Study population}

Parents of all children born between 1-6-2004 and 31-12-2004 in the province of Limburg, in the South East of the Netherlands, received the routine invitation for the hearing screen at age nine months by means of the distraction hearing test (CAPAS, Compact Amsterdam Paedo-Audiometrical Screening), along with information about this study, a consent form and the 
PEPPER questionnaire. The parents were asked to complete the questionnaire and the consent form, and to bring both to the well-baby clinic at the screening visit. The results of the questionnaire were not shared with the well-baby clinic doctors in order to ensure that routine practice procedures were maintained.

All parents who returned the PEPPER questionnaire received the Q21 follow-up questionnaire at the child's age of 21 months. The present sample consists therefore of those children for whom the data of the hearing screening data, a completed PEPPER questionnaire and a completed followup questionnaire form were all present.

Specific approval of an ethical commission was not needed, as the outcome of the questionnaire was unknown to the well-baby clinic doctors and therefore it did not change practice at the well-baby clinic. Written informed consent was obtained from all the parents of the children participating in the study.

The questionnaires were scanned and the responses entered into an SPSS file (version 15.0), and thereafter checked and merged with the CAPAS data. Excluded from the study database were children known to have a sensorineural hearing loss or permanent conductive hearing loss and children with Down syndrome and cleft palate or other craniofacial malformations. The latter provide sufficiently strong risk factors on their own to drive the management of the few cases involved.

\section{Statistical Analysis}

The response rate to the Q21 questionnaire was investigated for potential selection bias.

Univariate logistic regression was performed on the cases which had data for both the PEPPER questionnaire and the Q21 questionnaire. To facilitate the identification of potential predictors, two strategies were followed. First, two equally sized disjunctive data sets were randomly created from the entire dataset and each of the potential risk factors was examined relative to the outcome variable 'treatment with tubes'. Second, as both 'being a boy' and 'having siblings' predicted the outcome in the total dataset as well as in both at random chosen subsets and these items could therefore be considered as 
strong predictors, the total data set was split into four subsets accordingly. Univariate logistic regression was then applied to each of the PEPPER items separately for each of the subsets to reduce the possibility of overlooking potential explanatory factors. Making a univariate association, a prerequisite in this way, economises degrees-of-freedom and avoids unstable or uninterpretable entries with negative sign being used in the multivariate modelling.

Some responses were particularly thinly spread and their analysis would have been unreliable, so certain response categories were collapsed. 'Having cold symptoms' and 'nasal congestion' were applied in dichotomous form, where 'yes' comprises 'often' and 'always' responses, and 'no' comprises 'never', 'seldom', 'only with a cold' and 'not applicable'. 'Number of ear infections in the past three months', 'siblings with OM problems' and 'crèche with $>4$ children' were also shrunk to a dichotomous form.

'Smoking' was used as a dichotomised variable where 'yes' means $>1$ person smoking around the child or $\geq 20$ cigarettes being smoked in the household.

Results from the univariate analyses led to various further constraints on the multivariate analysis as follows. Breastfeeding appeared to be a risk for surgical treatment with tubes: this 'finding' is counterintuitive and could reflect a shared socio-cultural bias in both referral and breastfeeding. As we did not want any resulting procedure to be socially discriminatory, we excluded breastfeeding from the modelling procedure. However, 'being exclusively bottle fed', did appear to be a risk factor and was included in the modelling procedure. 'Father working part time', was also a significant predictor in the univariate analysis. But, as working status of the parents was also likely to be more a socio-cultural factor than a marker of social economic status, it too was left out of the modelling stage. Those children that failed the hearing screen in winter had increased odds for treatment with tubes, which was expected as OM is a seasonal fluctuating disease with a higher prevalence in autumn and winter. However, as the item 'season in which the child was screened for hearing loss' cannot be used as a predictor for tube insertion in the current absence of the hearing screen at 9 months of age, it was excluded in the further analysis. 
Any item having an at least marginally significant Odds Ratio (OR), defined as $\mathrm{p}<0.20$, and an expected direction in the univariate analyses in the different subsets was then considered as a candidate predictor for the multivariate model. The low threshold of $p<0.20$ was used to increase the possibility of finding a predictive model, as some items could be nonsignificant predictors in isolation ( $\mathrm{p}>0.05$ ) but could, when combined with other items, enhance the prediction from the model. Logistic regression with one by one stepwise backwards deletion of the weakest predictor, was applied to each subset (by sex and siblings) to determine which reduced combination of variables together would best predict the outcome. The regression thus obtained offers a scoring formula to calculate the probability of the pathological value of the outcome measure, that can predict probability of this outcome for individual cases. These case probability values were saved and used as input values for the construction of ROC (receiver operating characteristic) curves, which represent the relation between sensitivity and specificity of the model or tool in discriminating the outcome. To determine the optimal cut-off point for prediction, the Youden index $(\mathrm{J})$ was calculated as a measure of overall diagnostic effectiveness to enable the selection of an optimal cut-off point value. $J$ occurs where the distance or difference between the ROC curve and the diagonal or chance line is maximal, i.e. at the cut-point that optimizes the instrument's differentiating ability: $\mathrm{J}=\max ($ Sensitivity + Specificity -1$)$.

Initially, we were also interested in those children who on failing the hearing screen three times, were referred, did not consult their GP with ear and/or hearing problems at any time other than for failing the hearing screen, yet in the end were treated with tubes; as these children could be defined as having OM-related hearing loss without other parent reported ear problems. Only 45 children met all these criteria, too few to analyse.

The statistical software package SPSS 15.0 was used. 


\section{RESULTS}

A flow chart was constructed to present questionnaire response, referral and treatment with tubes (Figure 1). A total of 10803 children were born from 11-2004 to 31-12-2004 in Limburg, and the PEPPER questionnaire was sent to those 6573 children born from 1-6-2004 to 31-12-2004.

Figure 1. Flow chart of stages in inclusion plus number of children invited for the hearing screen and response rates for the PEPPER questionnaire, hearing screen and Q21 questionnaire.

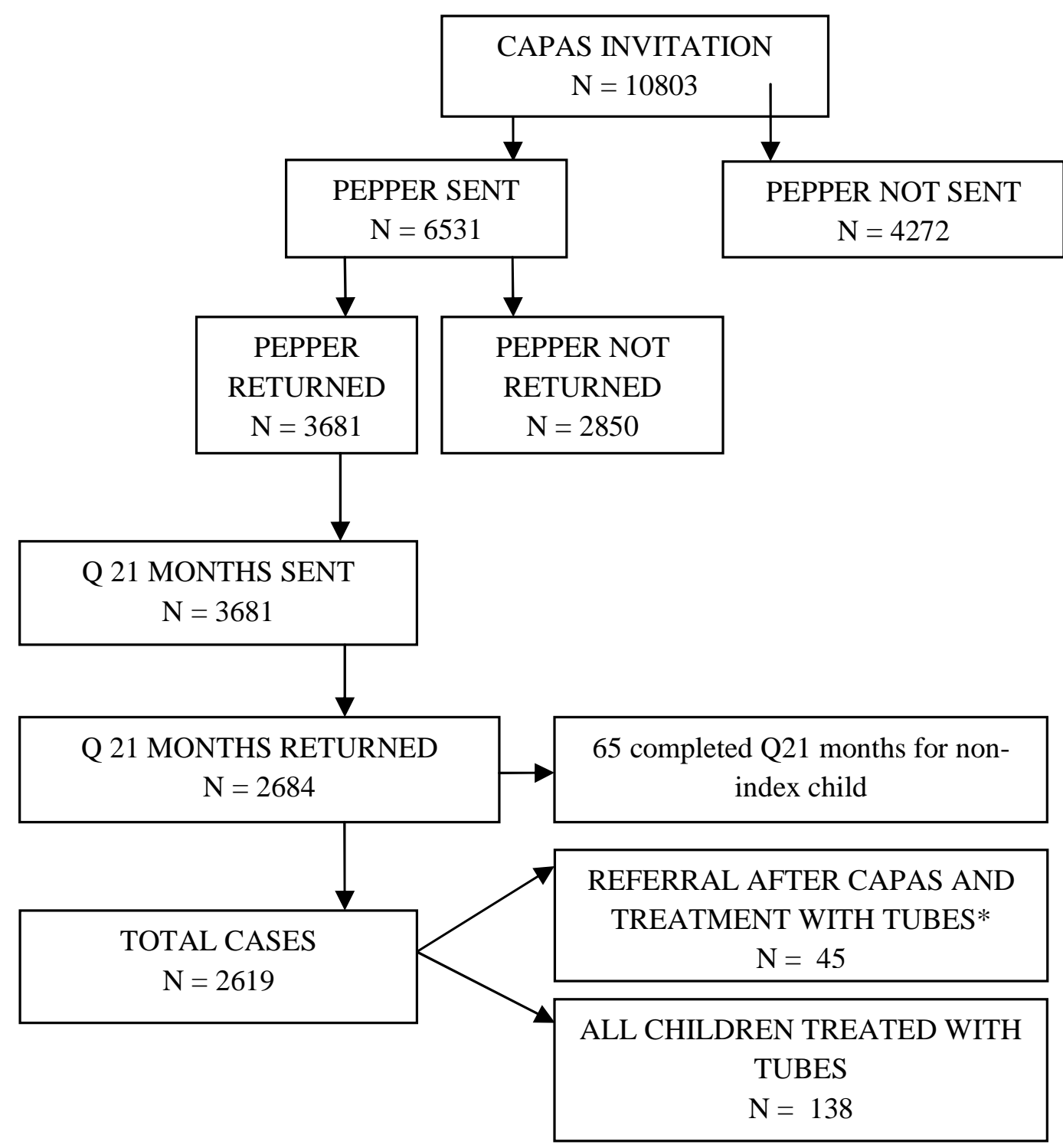

*without consulting their GP with other ear/hearing problems besides failing the hearing screen 
Only $39 \%$ of the children failing the screen repeatedly and with no other complaints were eventually recorded as treated with tubes. However, for those failing and with other complaints, this rose to 57\% . Looking backwards, of all children treated with tubes $60 \%$ had had ear and/or hearing complaints but had not failed the hearing screen; $21 \%$ had failed the hearing screen but with no complaints, whilst $11 \%$ had failed the screen with complaints.

Univariate analyses performed on the total dataset and the two at random chosen subsets found statistically significant $(\mathrm{p}<0.05)$ in prediction of the outcome 'treatment with tubes' for 10 items, all in the anticipated direction. These items, found in at least one of the analyses, were 'male gender', 'slowto-feed', 'ear infection in the last 3 months', 'ear infection in the last month', 'severe nasal congestion', 'having severe cold symptoms', 'attending day care', 'attending day care with $>4$ children' and 'having siblings' and 'being exclusively bottle fed'.

Table 1. Statistically significant items, for the total dataset and for four different subsets based on gender and having siblings, predicting 'treatment with tubes' (regardless of referral). The OR is given, with the significance level.

\begin{tabular}{|c|c|c|c|c|c|}
\hline \multicolumn{6}{|c|}{ Treatment with tubes } \\
\hline $\mathbf{N}$ & $\begin{array}{l}1 \hat{0}+\text { sib } \\
662\end{array}$ & $\begin{array}{l}\hat{0} \text {-sib } \\
618\end{array}$ & $\begin{array}{l}q+\text { sib } \\
665\end{array}$ & $\begin{array}{c}9 \text {-sib } \\
645 \\
\end{array}$ & $\begin{array}{c}\text { Total dataset } \\
2590 / 2619 \\
\end{array}$ \\
\hline & OR & OR & OR & OR & OR \\
\hline Sucking is weak & $2.8^{2}$ & $8.4^{4}$ & - & $10.3^{3}$ & $3.7^{4}$ \\
\hline Age first ear infection & & & & & \\
\hline 0-5 months & $6.3^{4}$ & $7.9^{4}$ & $6.5^{4}$ & - & $7.2^{4}$ \\
\hline 6-9 months & $2.7^{4}$ & $3.1^{2}$ & - & $6.8^{3}$ & $2.7^{4}$ \\
\hline Ear infection last 3 months & $3.8^{4}$ & $3.8^{4}$ & $2.4^{4}$ & $6.2^{3}$ & $2.8^{4}$ \\
\hline Ear infection last month & $3.4^{4}$ & $7.2^{4}$ & $2.6^{2}$ & - & $4.2^{4}$ \\
\hline Hearing problem & $3.3^{2}$ & $6.1^{2}$ & - & $11.5^{2}$ & $3.6^{4}$ \\
\hline Mouth breathing & $3.2^{4}$ & - & $3.2^{4}$ & $4.5^{2}$ & $3.1^{4}$ \\
\hline Nasal congestion & $4.5^{4}$ & - & $6.2^{4}$ & - & $4.8^{4}$ \\
\hline Having cold symptoms & $3.0^{4}$ & $3.0^{3}$ & $4.5^{4}$ & $5.9^{3}$ & $4.1^{4}$ \\
\hline Day care & $3.0^{4}$ & $2.5^{2}$ & $2.2^{2}$ & $9.7^{2}$ & $2.6^{4}$ \\
\hline Day care $>4$ children & $4.2^{4}$ & $3.7^{4}$ & $2.6^{3}$ & $12.8^{4}$ & $3.7^{4}$ \\
\hline Bottle fed exclusively & - & - & - & - & $1.3^{1}$ \\
\hline Male gender & & & & & $2.2^{4}$ \\
\hline Having siblings & & & & & $2.6^{4}$ \\
\hline
\end{tabular}

$1: p<.10 ; 2: p<.05 ; 3: p<.01 ; 4: p<.005 ;-$-: OR not significant

$\hat{O}=$ boys $;$ q $=$ girls; sib = siblings 
Table 2. Logistic regression model for 'treatment with tubes'.

Gender (=male)

Having siblings

Siblings with $\mathrm{OM}$

Day care $>4$ children

Being exclusively bottle fed

Having cold symptoms

Nasal congestion

Ear infection last 3 months

Sucking was weak

Smoking

\section{Treatment with tubes}

\begin{tabular}{lll} 
Coefficient & OR $(95 \%$ CI $)$ & p-value \\
\hline 0.6 & $1.9(1.3-4.7)$ & .001 \\
0.6 & $1.9(1.2-2.9)$ & .004 \\
0.4 & $1.4(0.9-1.2)$ & .104 \\
1.2 & $3.2(2.2-4.7)$ & .000 \\
0.3 & $1.4(0.9-2.0)$ & .112 \\
0.4 & $1.5(1.0-2.3)$ & .066 \\
0.9 & $2.4(1.5-3.8)$ & .000 \\
0.8 & $2.3(1.6-3.5)$ & .000 \\
0.7 & $2.1(1.0-4.2)$ & .045 \\
0.7 & $2.0(0.9-4.6)$ & .121 \\
& &
\end{tabular}

Multivariate modelling was first applied to the total dataset. Gender and 'having siblings' were then used to create the four subsets. Table 1 shows the items that significantly predicted 'treatment with tubes' in each of the four subsets. Table 2 shows the resulting models for each subset.

Figure 2. Scoring sheet predicting 'treatment with tubes'.

\begin{tabular}{llll|l}
\hline Item & No & Yes & OM score \\
\hline Boy? & 0 & 6 & \\
\cline { 4 - 5 } Siblings? & 0 & 6 & \\
Siblings with OM? & 0 & 4 & \\
Day care >4 children? & 0 & 12 & \\
Bottle fed only? & 0 & 3 & \\
Weak sucker? & 0 & 7 & \\
\cline { 4 - 5 } Smoking $\geq 20$ cigarettes or $>1$ & 0 & 7 & \\
$\quad$ smoker around the child? & & & \\
Ear infection last 3 months? & 0 & 8 & \\
Often cold symptoms? & 0 & 4 & \\
Often stuffed nose? & 0 & 9 & \\
\hline TOTAL & & & \\
\hline
\end{tabular}

If total 20 or more then referral

Estimation of this model for each of the subsets separately resulted in negligible differences in the coefficients for the risk factors and therefore one scoring sheet was derived. The scoring sheet (Figure 2) was obtained by multiplying each coefficient by 10 to obtain scores ranging from 0 to 61 . Examination of the Youden index suggested an optimum cut-off probability 
of 0.05 or 0.06 . A score of 20 corresponded with a cut off probability of 0.05 while a score of 22 corresponded with a cut off probability of 0.06 . (Figure 3)

Figure 3. Curve of the Youden index, showing the maximum indexes at 0.45 (horizontal line) at a cut-off value of 0.05 and 0.46 at 0.06 respectively.

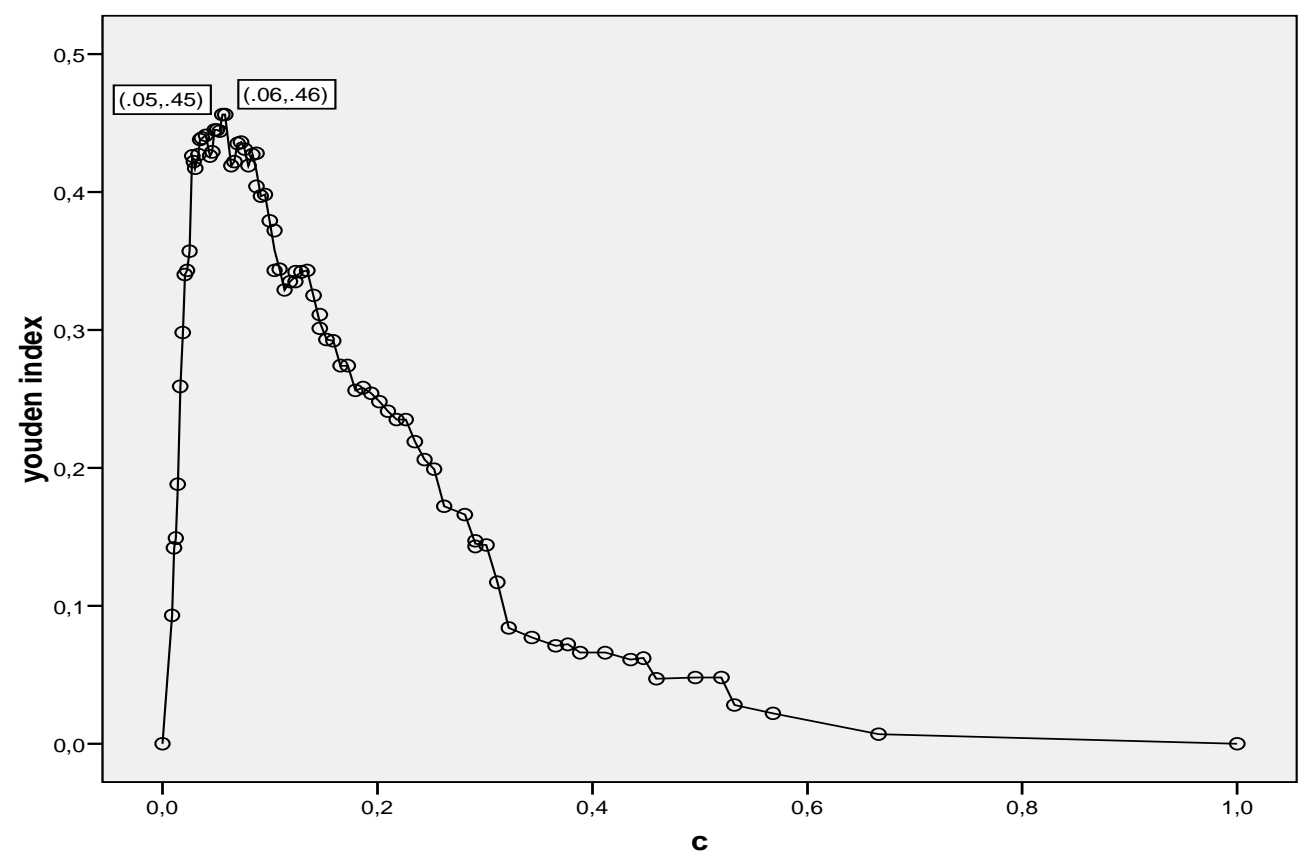

Figure 4. ROC curve of the score derived with the scoring sheet, i.e. how well does the scoring sheet predict tubes insertion.

Roc Curve

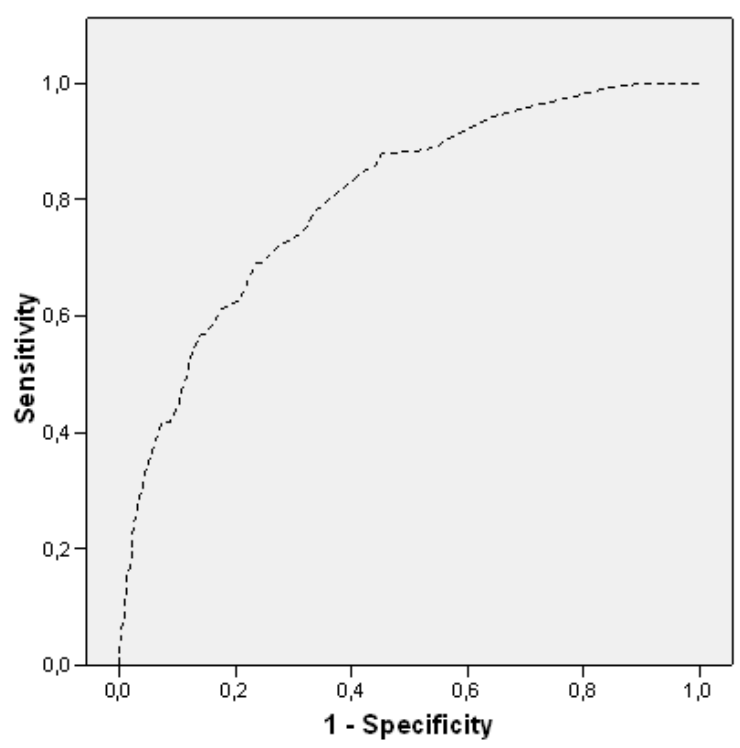


A ROC curve was calculated (Figure 4) for how well the scoring sheet predicted the outcome 'treatment with tubes' in the whole dataset. The area under the curve was 0.801 (CI: 0.76-0.84).

Table 3 and 4 show the classification tables according to the cut-off point (predicted versus observed) with a Youden index of 0.05 (sensitivity $=0.72$ and specificity $=0.73$ ). Opting for fewer false positives would suggest taking the second best Youden index with a cut-off point of 0.06 (sensitivity $=0.69$ and specificity $=0.76$ ).

Table 3. Classification Table (Youden index cut-off point $=0.05$ ).

\begin{tabular}{ccccc}
\hline & \multicolumn{2}{l}{ Predicted Tubes } & \\
\cline { 3 - 4 } Observed Tubes & No tubes & Tubes & & $\%$ correct \\
\cline { 1 - 1 } No tubes & 1779 & 672 & 72.6 \\
Tubes & 39 & 100 & 71.9 \\
Overall \% & & & 72.5 \\
\hline
\end{tabular}

Table 4. Classification Table (Youden index cut-off point $=0.06$ ).

\begin{tabular}{cclll}
\hline & \multicolumn{2}{l}{ Predicted Tubes } & \\
\cline { 3 - 4 } Observed Tubes & No tubes & Tubes & & $\%$ correct \\
\cline { 1 - 1 } No tubes & 1857 & 576 & & 76.5 \\
Tubes & 43 & 96 & 69.1 \\
Overall \% & & & 76.1 \\
\hline
\end{tabular}

\section{DISCUSSION}

\section{Main findings}

In this study we explored the possibility of using risk factor items for OM to create an instrument aiding the GP in selecting those children (aged 0-3 years) with OM that need referral and further assessment. Multivariate modelling was applied to the total dataset and the four subsets. One model was created for the total dataset. Estimation of this model for each of the subsets separately resulted in negligible differences in the coefficients for the risk factors and therefore one scoring sheet was derived. The scoring formulae that predict treatment with tubes gives a ROC curve area of 0.801: a reasonably good prediction instrument. Classically, the choice of a particular cut-off requires judging the balance between the number of false- 
positives and false-negatives. The Youden index takes into account the range of such cut-offs for which the instrument used may have particular accuracy. Recent studies ${ }^{18}$ show that overall policy in OM has shifted towards more restriction with watchful waiting and not too many children being treated, suggesting that in a current application, the instrument should be used with a cut-off favouring high specificity. A Youden index value of 0.05 gives a specificity of 0.73 and a sensitivity of 0.72 . If a higher specificity is preferred, the second best Youden index value of 0.06 gives a specificity of 0.76 and a sensitivity of 0.69 .

\section{Strengths and limitations}

We used the data of a large group of otherwise healthy children who were routinely invited for the hearing screen at nine months. Combining the results of this hearing screen together with the data from the two questionnaires resulted in a very large dataset of high statistical power. The original aim was to analyse the data from those children that only had OMrelated hearing loss. Unfortunately, the number of children that failed the hearing screen, were referred and in the end were treated with tubes was too low to permit analysis. Therefore, we focussed on creating an instrument predicting treatment with tubes.

$\mathrm{OM}$ is a fluctuating disease and we do not know which children from the entire dataset were treated for wise clinical reasons, nor which such children were missed and not treated at all, yet could have benefitted from treatment. Many children in the Netherlands are referred by their GP to the ENT department due to reluctance to prescribe antibiotics and this can in part explain the high number of surgical procedures for OM in the Netherlands, an aspect providing statistical power to the present study. It may perhaps not be representative for other healthcare systems. Extrapolating the results from this study to other countries raises two issues: external validity of the particular risk factors used, and appropriate cut-off values. Risk factors can differ between countries ${ }^{19}$ with grossly different standards of living, or health and social care arrangements or health practices and belief systems (e.g. background levels of smoking). However, where the model in Table 2 and Figure 2 does not suffer limited applicability from such differences, they provide strong a priori suggestions for efficient combinations of risk factors elsewhere. The local placement of a cut-off will be related to local 
intervention rates, thus reflecting policy and practice, so any extrapolation of the cut-offs should be done with awareness of this.

The response rate to the PEPPER questionnaire was 56.4\%. To determine any participation bias, we compared the responders to the non-responders. Fewer children of responders did not attend the first hearing screen compared to non-responders (3.6\% versus $14.8 \%$ ). This follows from the PEPPER questionnaire being completed and brought to the well-baby clinic at first test. Furthermore, the non-responders lived in areas with relatively higher percentage migrant population, more unemployment, and lower incomes which indicate a lower SES and this could explain the nonresponding ${ }^{20}$. However, there appeared to be no bias in respect of referral. Slightly fewer children from responders were referred compared to nonresponders (3.1\% versus 3.6\%, not statistically significant different). Thus we appear to be reporting on a sub-population with a high participation rate both in research and routine service, but without a difference in the average outcomes considered. The response rate to the Q21 questionnaire was higher (72.9\%). This second questionnaire was only sent to those parents who had already replied to the first questionnaire, and a higher response rate was therefore to be expected.

\section{Future research}

The created instrument looks promising as predictor for which children (should) receive tube treatment. The next step could be a prospective evaluation in selected GP practices to further study the possibility of using the instrument to select children with OM that might benefit from referral to ENT.

\section{CONCLUSION}

The present study is a first attempt to create a case-finding instrument for the subgroup of children with OM needing referral and further assessment. A reasonably strong risk factor model for predicting tube insertion was found. The developed scoring sheet with 10 items, e.g. to be used in combination with physical examinations and tympanometry looks promising, although the practical problems of routine implementation remain to be evaluated. 


\section{REFERENCES}

1. Engel J, Anteunis L, Volovics A, Hendriks J, Marres E. Prevalence rates of otitis media with effusion from 0 to 2 years of age: healthy-born versus highrisk-born infants. Int J Pediatr Otorhinolaryngol 1999;47:243-251.

2. Midgley EJ, Dewey C, Pryce K, Maw AR. The frequency of otitis media with effusion in British pre-school children: a guide for treatment. ALSPAC Study Team. Clin Otolaryngol Allied Sci 2000;25:485-491.

3. Paradise JL, Rockette HE, Colborn DK, Bernard BS, Smith CG, Kurs-Lasky $\mathrm{M}$, et al. Otitis media in 2253 Pittsburgh-area infants: prevalence and risk factors during the first two years of life. Pediatrics 1997;99:318-333.

4. Zielhuis GA, Rach GH, Van den Broek P. The occurrence of otitis media with effusion in Dutch pre-school children. Clin Otolaryngol Allied Sci 1990;15:147-153.

5. www.nivel.nl.

6. Lok W, Anteunis LJC, Chenault MN, Meesters C, Haggard MP. Screening for hearing loss versus parental concern because of ear and/or hearing problems and subsequent referral and treatment for otitis media in the Netherlands. Submitted for publication

7. Rovers MM, Straatman H, Ingels K, van der Wilt GJ, van den Broek P, Zielhuis GA. The effect of ventilation tubes on language development in infants with otitis media with effusion: A randomized trial. Pediatrics 2000;106:E42.

8. Simpson SA, Thomas CL, van der Linden MK, Macmillan H, van der Wouden JC, Butler C. Identification of children in the first four years of life for early treatment for otitis media with effusion. Cochrane Database Syst Rev 2007:CD004163.

9. Lok W, Chenault MN, Anteunis LJ. Implementation of neonatal screening for hearing impairment: influence on pediatric otitis media surgery in The Netherlands. Int J Pediatr Otorhinolaryngol 2009;73:1090-1094.

10. Anteunis L, Engel J, Hendriks J, Volovics A, Chenault MN, Manni JJ. Otitis media with effusion-algorithms and the associated hearing loss in infants 0-2.: Maastricht University Medical Centre, 2000:141-154.

11. Fria TJ, Cantekin EI, Eichler JA. Hearing acuity of children with otitis media with effusion. Arch Otolaryngol 1985;111:10-16.

12. Bennett KE, Haggard MP, Silva PA, Stewart IA. Behaviour and developmental effects of otitis media with effusion into the teens. Arch Dis Child 2001;85:91-95.

13. Casselbrant ML, Villardo RJ, Mandel EM. Balance and otitis media with effusion. Int J Audiol 2008;47:584-589.

14. Mott A, Emond A. What is the role of the distraction test of hearing? Arch Dis Child 1994;70:10-13.

15. Rovers MM, Straatman H, Zielhuis GA, Ingels K, van der Wilt GJ. Seasonal variation in the prevalence of persistent otitis media with effusion in one-yearold infants. Paediatr Perinat Epidemiol 2000;14:268-274.

16. Rovers MM, Zielhuis GA, Straatman H, Ingels K, van der Wilt GJ, Kauffmande Boer M. Comparison of the CAPAS and Ewing tests for screening of hearing in infants. J Med Screen 1999;6:188-192. 
17. Haggard MP, McCormick B, Gannon MM, Spencer H. The paediatric otological caseload resulting from improved screening in the first year of life. Clin Otolaryngol Allied Sci 1992;17:34-43.

18. Browning GG, Rovers MM, Williamson I, Lous J, Burton MJ. Grommets (ventilation tubes) for hearing loss associated with otitis media with effusion in children. Cochrane Database Syst Rev 2010:CD001801.

19. Rovers MM, de Kok IM, Schilder AG. Risk factors for otitis media: an international perspective. Int J Pediatr Otorhinolaryngol 2006;70:1251-1256.

20. Martikainen P, Laaksonen M, Piha K, Lallukka T. Does survey non-response bias the association between occupational social class and health? Scand J Public Health 2007;35:212-215. 


\section{DISCUSSION}


Otitis media $(\mathrm{OM})$ is very common in infants. In otitis media with effusion, the essential feature is fluid in the middle ear. Otitis media with effusion often follows signs and symptoms of an acute infection (i.e. fever and pain: acute otitis media) but sometimes occurs without these preceding acute symptoms. Usually the condition is relatively mild and self-limiting. The fluid in the middle ear can however persist for a longer period of time, causing hearing loss and other types of sequelae. Cases with persisting nontrivial hearing loss due to OM can experience developmental problems such as delayed speech and language development ${ }^{1}$ and associated behaviour problems $^{2}$.

$\mathrm{OM}$, and the accompanying hearing loss, can easily be treated with the insertion of ventilation tubes in the eardrum ${ }^{1}$. The fluid in the middle ear is then cleared and the hearing restored. ENT specialists, as well as other doctors, know how effective treatment of OM can sometimes be. Parents often report a remarkable developmental jump after the treatment.

At the start of this research we hypothesized that by replacing the hearing screen at nine months with the neonatal screen, children with OM-related hearing loss would be overlooked. The increase in children treated with tubes might suggest the opposite, i.e. that there is overtreatment of a condition that can be relatively mild and self-limiting.

Since the treatment with tubes has to be done under general anaesthesia overtreatment should be avoided. On the other hand, children at risk for developmental problems as a result of OM-related hearing loss should not be missed. This calls for a case-finding instrument which is both sensitive and specific and will only detect children with OM who are at risk for developmental problems. The question therefore is: How can we recognise those children with OM that might benefit from treatment?

There are four guidelines in the Netherlands regarding OM which can help in deciding when a child with OM should be referred for further assessment and subsequent surgical treatment.

- The Dutch College of General Practitioners (Nederlandse Huisartsengenootschap) has published two guidelines regarding OM. The first general practitioner (GP) guideline regarding acute otitis media (AOM) was published ${ }^{3}$ in 1990 with revisions in $1999^{4}$ and in $2006^{5}$. This 
guideline recommends that children should be referred to an ENT specialist when a child has recurrent AOM, when otorrhoea persists and/or when a perforation persists. The definition of recurrent AOM is a child having had $\geq 3$ of AOM in half a year, or $\geq 4$ in one year.

- In $1991{ }^{6}$ the second GP guideline was published. This guideline addressed otitis media with effusion (OME) and was revised in $2000^{7}$ and $2005^{8}$. It advises that a child should be referred to an Ear, Nose, Throat (ENT) specialist for evaluating the need for treatment whenever there is a bilateral OME present for up to 9 months, with accompanying hearing loss that influences functioning and development of the child.

- The Dutch Society of ENT and Head and Neck Surgery published one guideline in 1998, discussing the hearing impaired child ${ }^{9}$. It advises to treat a child with ventilation tubes when there has been a long lasting (> 3 months) and/or recurrent otitis media. If OME is accompanied by speech and language problems, a more active policy is necessary.

- In 1992 a consensus statement on therapy in AOM was formed by CBO ${ }^{10}$ in conjunction with the Dutch College of General Practitioners, The Dutch Society of Allergy, the Dutch Society of ENT and Head and Neck Surgery, The Dutch Society of Paediatricians, the Dutch Society of Laboratory Doctors, and the Dutch Society of Infectious Diseases. This consensus statement discusses the therapeutic options for AOM.

Treatment with tubes and/or adenoidectomy is advised when a child has recurrent AOM.

These guidelines do not specifically address how to assess hearing loss caused by OM, which can be difficult in very young children. Therefore the decision for referral and/or treatment for those children with OM without AOM complaints remains a challenge in The Netherlands. Similar uncertainties remain in other countries despite comparable guidelines.

Researchers have tried to identify risk factors associated with OM in an attempt to single out those children in need of medical attention. In Table 1 studies regarding risk factors for $\mathrm{OM}$ in young children are listed, together with a description of the study population and the used outcome variable. Comparison of these studies is difficult because of varying outcome measures and sometimes differing study populations. The studies usually 
only addressed isolated risk factors without creating a scoring system of optimal combination of items, i.e. an instrument to be used in daily practice.

Table 1 Description of articles studying risk factors for OM in infants

\begin{tabular}{|c|c|c|}
\hline Author & Study population & Outcome variable \\
\hline Alho ${ }^{11}$ & $\begin{array}{l}\text { Infants } 0-24 \text { months } \\
\text { Healthy infants, random sample } \\
\text { of a retrospective birth cohort. }\end{array}$ & $\begin{array}{l}\text { OME }=\text { minimum of } 2 \text { months of middle ear } \\
\text { effusions, found at regular checkups with } \\
\text { pneumatic otoscopy }\end{array}$ \\
\hline Daly $^{12}$ & $\begin{array}{l}\text { Infants } 0-6 \text { months } \\
\text { Healthy infants. }\end{array}$ & $\begin{array}{l}\frac{\mathrm{AOM}}{\mathrm{AOM}} ; \mathrm{ROM}=2 \text { physician diagnosed episode of } \\
\text { or OME by } 6 \text { months of age }\end{array}$ \\
\hline Damoiseaux $^{13}$ & $\begin{array}{l}\text { Infants } 0-24 \text { months } \\
\text { Children presenting with AOM at } \\
\text { the general practitioners' office }\end{array}$ & $\begin{array}{l}\text { Recurrent } \mathrm{AOM}=\text { at least one episode of } \\
\text { AOM within } 6 \text { months after the initial } \\
\text { presentation with AOM } \\
\text { Persistent MEE }=\text { uni- or bilateral MEE at all } \\
\text { follow-up visits at } 6 \text { weeks, } 3 \text { and } 6 \text { months }\end{array}$ \\
\hline Dewey $^{14}$ & $\begin{array}{l}\text { Infants } 8 \text { months- } 3.5 \text { years } \\
\text { Healthy children; ALSPAC study }\end{array}$ & $\frac{\text { Bilateral OME }}{\text { tympanogram }}=$ for both ears type $\mathrm{B}$ \\
\hline Engel ${ }^{15}$ & $\begin{array}{l}\text { Infants } 0-2 \text { years } \\
150 \text { healthy and } 100 \text { high risk } \\
\text { born infants, all born in hospital }\end{array}$ & $\begin{array}{l}\text { Unilateral or bilateral OME = presence of } \\
\text { glue, fluid lines, hyperaemia or otorrhoe with } \\
\text { otoscopy or type B tympanogram }\end{array}$ \\
\hline Gliddon $^{16}$ & $\begin{array}{l}\text { Infants } 0-8 \text { months } \\
100 \text { Special Care Baby Unit } \\
\text { children and } 100 \text { healthy children }\end{array}$ & $\begin{array}{l}\text { MEE at } 8 \text { months } \\
\text { negative } \text { MEP; } \text { flat tympanogram or } \\
\text { tympanogram and negative MEP: see article }\end{array}$ \\
\hline Kraemer $^{17}$ & $\begin{array}{l}\text { Infants around } 1 \text { year of age } \\
\text { Children attending the hospital } \\
\text { for tubes and children admitted } \\
\text { for non otolaryngology related } \\
\text { surgical procedures }\end{array}$ & $\begin{array}{l}\text { PMEE }=\text { bilateral effusions (with pneumatic } \\
\text { otomicroscopy and tympanometry) not } \\
\text { resolving after } 8 \text { or more weeks of medical } \\
\text { therapy, and with a hearing loss }>/=25 \mathrm{~dB}\end{array}$ \\
\hline Owen $^{18}$ & $\begin{array}{l}\text { Infants } 0 \text { - } 2 \text { years } \\
\text { Healthy infants }\end{array}$ & $\begin{array}{l}\underline{\mathrm{OME}}=\text { otorrhoe, an acoustic reflectivity }>/= \\
5, \text { or a type } \mathrm{B} \text { tympanogram; Percent of days } \\
\text { with bilateral versus unilateral OME }\end{array}$ \\
\hline Paradise $^{19}$ & $\begin{array}{l}\text { Infants } 0 \text { - } 2 \text { years } \\
\text { Healthy infants }\end{array}$ & $\begin{array}{l}\text { MEE }=\text { all types of otitis media. } \\
\text { AOM with or without otorrhoe, OME or } \\
\text { otorrhoe through a tympanostomy tube }\end{array}$ \\
\hline Rovers $^{20,21}$ & $\begin{array}{l}\text { Infants } 1-2 \text { years } \\
\text { Healthy infants }\end{array}$ & $\begin{array}{l}\text { Persistent bilateral OME }=\text { a type } \mathrm{B} \\
\text { tympanogram and/or fluid found during } \\
\text { otoscopy, during } 3 \text { out of } 4 \text { bimonthly visits } \\
\text { over a } 6 \text { month period }\end{array}$ \\
\hline Sassen $^{22}$ & $\begin{array}{l}\text { Infants } 0 \text { - } 2 \text { years } \\
\text { Healthy infants }\end{array}$ & $\begin{array}{l}\text { OME }=\text { inflammation of the middle ear } \\
\text { accompanied by accumulation of liquid in the } \\
\text { middle ear without signs of an acute } \\
\text { infection; Type B tympanogram }\end{array}$ \\
\hline Zielhuis $^{23}$ & $\begin{array}{l}\text { Infants 2-3.5 year } \\
\text { Healthy infants, KNOOP study }\end{array}$ & $\begin{array}{l}\text { OME }=\text { uni-/bilateral type B tympanogram at } \\
\text { one screening after a normal tympanogram } \\
\text { (non type B) at the previous screening }\end{array}$ \\
\hline
\end{tabular}

$\mathrm{PMEE}=$ persistent middle ear effusion; $\mathrm{AOM}=$ acute otitis media; $\mathrm{ROM}=$ recurrent otitis media; OME=otitis media with effusion; type B tympanogram = according to Jerger classification; ENT=ear, nose, throat; ALSPAC = Avon Longitudinal Study of Pregnancy and Childhood; $\mathrm{MEE}=$ middle ear effusion; $\mathrm{MEP}=$ middle ear pressure 
Furthermore, most of these studies do study risk factors for OM, but they do not study persisting OM-related hearing loss. As it is the hearing loss that can cause developmental problems, it is particularly the subset of $\mathrm{OM}$ children with such hearing loss that need to be identified.

A set of risk factor items incorporated into a short questionnaire could be a useful, practical and easy-to-use instrument for selecting children with persistent $\mathrm{OM}$ and accompanying developmental problems.

Mary Gannon and Mark Haggard (Cambridge, United Kingdom) started the development of such an instrument and designed the original PEPPER study. Based on the PEPPER item pool, we tried to develop a case-finding instrument.

The PEPPER questionnaire was sent to 6000 children together with the invitation for the hearing screen at age nine months (Chapter 5). The response rate (56.4\%) was lower than expected from the experience of the well-baby clinics. The number of 3681 usable returned questionnaires is however high enough for psychometric reliability. The response rate could possibly have been improved by a pre-notification and/or a reminder ${ }^{24}$. To estimate bias in participation, we compared the responders to the nonresponders. More children of responders attended the first hearing screen compared to non-responders (96.4\% versus $85.2 \%$ ). The PEPPER questionnaire was to be completed and brought to the well-baby clinic during the first testing, probably explaining why relatively more completed questionnaires were obtained from the group attending the hearing screen. Furthermore, the non-responders lived in areas with relatively higher percentage of migrants, more unemployment, and lower incomes which indicate a lower SES. We did not find a difference in referral rates between responders and non-responders. It thus appears that we are reporting on a sub-population with a high participation rate both in research and routine service, but without differences in outcome measurement. Therefore, it is unlikely that the low response rate will influence our findings regarding items predictive of referral.

Most children failing the hearing screen (CAPAS) at nine months did so because of OM-related hearing loss ${ }^{25-27}$. In the Netherlands children were referred to their GP upon either failing the CAPAS three times or failing 
twice combined with other problems warranting referral, for example developmental problems or suspected severe hearing loss. Referral (i.e. failing repeatedly the CAPAS) was taken as marking the presence of persistent hearing loss and used in our analysis as the outcome variable. Nine items were found to be associated with a higher risk of referral after failing the hearing screen (Chapter 5):

- male gender

- having severe cold symptoms

- severe nasal congestion

- attending day care with $>4$ children

- having siblings

- siblings with OM

- season of CAPAS

- at least 3 months breastfeeding

- father working part-time

Four of these items were not used in further analysis. The item 'season of CAPAS' can only be used when the CAPAS is in use. As this screen has been replaced by the neonatal screen, it will not be of any use in the future. The season in which a child will present with complaints of OM is however important as $\mathrm{OM}$ is more prevalent in autumn and winter.

The results of both the items 'breastfeeding' and 'father working part-time' were puzzling. Counter-intuitively, 'breastfeeding' appeared to be a risk for referral. A possible reason for this (discussed in Chapter 5) is that the raised risk for referral with 'breastfeeding' might be a shared report bias. 'Exclusive bottle feeding', which did impose a risk for surgical treatment with tubes in the expected direction (Chapter 6) seems to confirm our suspicion about the direction paradox of the item 'breastfeeding'. From these considerations, we decided not to include 'breastfeeding' in further analysis. The item 'parents' working status' was included to capture socioeconomic status. 'Father working part time' appeared to be a risk for referral while 'mother's working status' was not. We do not know why 'father working part time' is a risk, and for example 'father working fulltime' or 'father not working' is not. Further research will be necessary to determine the meaning and usefulness of this item. 
The item 'siblings with a history of ear/hearing problems' (genetic predisposition) became non-significant when it was adjusted for 'having siblings' (exposure).

Therefore we concluded that we found five reliable risk factors, consistent with past literature to be predictive for referral: 'having severe cold symptoms', 'attending day care with $>4$ children', 'having siblings', 'severe nasal congestion' and 'male gender'.

It was uncertain to what extent referral after failing the hearing screen indicated persistent OM-related hearing loss. Some children failing the screen might have had spontaneous resolution of their OM-related hearing loss after referral. Therefore, we focussed on those children who were referred AND received surgical treatment for OM by means of insertion of ventilation tubes.

To determine whether or not a child received surgical treatment for OM, the 3681 children, for whom the first questionnaire had been returned, received the second questionnaire covering the history between birth and 21 months of age. There were 2690 questionnaires returned. Again we analysed the response rate and found that the responders more often lived in an area with a relatively lower percentage migrant population, less unemployment, and higher incomes than the non-responders. This indicates that the responders had a relatively higher SES. Lower SES often accompanies worse health and therefore more use of the health care system ${ }^{28}$, especially for conditions that are highly symptomatic and do not have a preventive, discretionary or awareness element. Therefore the present finding is consistent with differing SES gradients for consultation. Returning both questionnaires could also reflect more parental concern regarding ear and/or hearing problems, possibly leading to more or earlier referral. Therefore children of the responders could have had relatively fewer problems, but also be more readily referred and/or treated. This will not necessarily distort the profile of risk factors, but it implies that sensitivity to true impairments in the population of the resulting instrument will be lower than appears here.

The children who were treated surgically for OM after failing the hearing screen but had not visited their GP with ear/hearing complaints, were 
defined as those treated for persisting OM-related hearing loss.

Unfortunately there were only 45 children meeting this criterion, too few for data analysis. We therefore chose to analyse the data of all children who were treated with tubes (Chapter 6). We acknowledge that by doing this we might be including children treated at least in part for other reasons than OM-related hearing loss, such as children with recurrent acute otitis media or chronic otorrhoe. As a result, a case-finding instrument for children with OM was developed instead of a case-finding instrument for children with only OM-related hearing loss.

The developed case-finding instrument presented in Chapter 6 should be considered as a first attempt to select those children with OM in need of further assessment. The case-finding instrument should be refined in the future because in the current form still too many children will be referred for further assessment. Creating a case-finding instrument for boys and girls separately might be an option as we have found that some risk factors are also gender specific.

Another option which could be beneficial to the refinement of the casefinding instrument, is an analysis of the similarities and differences between countries. During our research we noted a remarkable high incidence of surgical treatment in the Netherlands compared to other countries (Table 2). On the other hand another study shows that the prescription of antibiotics for $\mathrm{OM}$ is very low in the Netherlands ${ }^{29}$. This relative high incidence of surgical treatment in the Netherlands may just reflect a preference for surgery. However, overtreatment of uncomplicated cases cannot be ruled out.

Table 2. Number of children treated with tubes in different countries.

\begin{tabular}{lcll}
\hline Country & $\begin{array}{c}\text { Number of children } \\
\text { treated with tubes }\end{array}$ & Age & Year \\
\hline Netherlands $^{\text {Lok }}$ & $41-46 / 1000$ & $0-2$ years & $2004-2007$ \\
Finland $^{30}$ & $9.7-14.7 / 1000$ & $0-7$ years & $1999+2005$ \\
Norway $^{30}$ & $11.9-12.3 / 1000$ & $0-7$ years & $1999+2005$ \\
Scotland $^{31}$ & $6.2 / 1000$ & $0-9$ years & 1994 \\
England $^{32}$ & $0.9-1.5 / 1000$ & $0-15$ years & $1996-1999$ \\
US $^{33}{ }_{\text {Australia }}{ }^{34}$ & $1-2 / 1000$ & $0-4$ years & $2003-2005$ \\
& $13-14 / 1000$ & $0-4$ years & $2000-2004$ \\
\hline
\end{tabular}


Ultimately, the case-finding instrument should be validated before it can be (fully) implemented in the Netherlands With such an instrument, the system can better select those children at risk for persistent OM and/or OM-related hearing loss. If only those children are referred for further assessment, the number of children treated surgically with tubes will decline. The quality of care will improve by increasing access for those children needing attention but at the same time avoiding unnecessary surgical procedures for those children with uncomplicated and self-limiting OM. 


\section{REFERENCES}

1. Lous J, Burton MJ, Felding JU, Ovesen T, Rovers MM, Williamson I. Grommets (ventilation tubes) for hearing loss associated with otitis media with effusion in children. Cochrane Database Syst Rev 2005:CD001801.

2. Bennett KE, Haggard MP, Silva PA, Stewart IA. Behaviour and developmental effects of otitis media with effusion into the teens. Arch Dis Child 2001;85:91-95.

3. Appelman CL, van Balen F, van de Lisdonk E, de Melker RA, van Weert H. NHG-standaard Otitis media acuta. Huisarts en Wetenschap 1991;33:242-245.

4. Appelman CL, Bossen P, Dunk J, van de Lisdonk E, van Weert H, Eizinga WH. NHG-standaard Otitis media acuta (eerste herziening). Huisarts en Wetenschap 1999;42:362-366.

5. Damoiseaux RA, van Balen F, Leenheer WAM, Kolnaar BGM. NHGstandaard Otitis media acuta bij kinderen (tweede herziening). Huisarts en Wetenschap 2006;49:615-621.

6. van de Lisdonk E, Appelman CL, Bossen P, de Melker RA, Dunk J, van Weert H. NHG-standaard Otitis Media met Effusie. Huisarts en Wetenschap 1991;34:426-429.

7. van de Lisdonk EH, van Balen F, van Weert H, Eekhof JAH, Appelman CLM, Eizinga WH. NHG-Standaard Otitis Media met Effusie bij kinderen (eerst herziening). Huisarts en Wetenschap 2000;43:171-177.

8. Wiersma T, Boomsma LJ. Herziene versie NHG-standaard otitis media met effusie. Huisarts en Wetenschap 2005;48:683.

9. Admiraal RJC, Engel JAM, Lem GJ, Van Zanten GA. De rol van de KNO-arts bij het slechthorende kind. Ned Tijdschr KNO-heelkunde 1998;4:58-73.

10. Hordijk GJ. [Consensus in the therapy of acute otitis media]. Ned Tijdschr Geneeskd 1992;136:85-88.

11. Alho OP, Oja H, Koivu M, Sorri M. Risk factors for chronic otitis media with effusion in infancy. Each acute otitis media episode induces a high but transient risk. Arch Otolaryngol Head Neck Surg 1995;121:839-843.

12. Daly KA, Brown JE, Lindgren BR, Meland MH, Le CT, Giebink GS. Epidemiology of otitis media onset by six months of age. Pediatrics 1999;103:1158-1166.

13. Damoiseaux RA, Rovers MM, Van Balen FA, Hoes AW, de Melker RA. Long-term prognosis of acute otitis media in infancy: determinants of recurrent acute otitis media and persistent middle ear effusion. Fam Pract 2006;23:4045.

14. Dewey C, Midgeley E, Maw R. The relationship between otitis media with effusion and contact with other children in a british cohort studied from 8 months to $31 / 2$ years. The ALSPAC Study Team. Avon Longitudinal Study of Pregnancy and Childhood. Int J Pediatr Otorhinolaryngol 2000;55:33-45.

15. Engel J, Anteunis L, Volovics A, Hendriks J, Marres E. Risk factors of otitis media with effusion during infancy. Int J Pediatr Otorhinolaryngol 1999;48:239-249.

16. Gliddon ML, Sutton GJ. Prediction of 8-month MEE from neonatal risk factors and test results in SCBU and full-term babies. Br J Audiol 2001;35:77-85. 
17. Kraemer MJ, Richardson MA, Weiss NSet al. Risk factors for persistent middle-ear effusions. Otitis media, catarrh, cigarette smoke exposure, and atopy. JAMA 1983;249:1022-1025.

18. Owen MJ, Baldwin CD, Swank PR, Pannu AK, Johnson DL, Howie VM. Relation of infant feeding practices, cigarette smoke exposure, and group child care to the onset and duration of otitis media with effusion in the first two years of life. J Pediatr 1993;123:702-711.

19. Paradise JL, Rockette HE, Colborn DKet al. Otitis media in 2253 Pittsburgharea infants: prevalence and risk factors during the first two years of life. Pediatrics 1997;99:318-333.

20. Rovers MM, Hofstad EA, Franken-van den Brand KIet al. Prognostic factors for otitis media with effusion in infants. Clin Otolaryngol Allied Sci 1998;23:543-546.

21. Rovers MM, Zielhuis GA, Straatman H, Ingels K, van der Wilt GJ, van den Broek P. Prognostic factors for persistent otitis media with effusion in infants. Arch Otolaryngol Head Neck Surg 1999;125:1203-1207.

22. Sassen ML, Brand H, Grote JJ. Risk factors for otitis media with effusion in children 0 to 2 years of age. Am J Otolaryngol 1997;18:324-330.

23. Zielhuis GA, Heuvelmans-Heinen EW, Rach GH, van den Broek P. Environmental risk factors for otitis media with effusion in preschool children. Scand J Prim Health Care 1989;7:33-38.

24. Eaker S, Bergstrom R, Bergstrom A, Adami HO, Nyren O. Response rate to mailed epidemiologic questionnaires: a population-based randomized trial of variations in design and mailing routines. Am J Epidemiol 1998;147:74-82.

25. Mott A, Emond A. What is the role of the distraction test of hearing? Arch Dis Child 1994;70:10-13.

26. Rovers MM, Straatman H, Zielhuis GA, Ingels K, van der Wilt GJ. Seasonal variation in the prevalence of persistent otitis media with effusion in one-yearold infants. Paediatr Perinat Epidemiol 2000;14:268-274.

27. Rovers MM, Zielhuis GA, Straatman H, Ingels K, van der Wilt GJ, Kauffmande Boer M. Comparison of the CAPAS and Ewing tests for screening of hearing in infants. J Med Screen 1999;6:188-192.

28. Reijneveld SA. Reported health, lifestyles, and use of health care of first generation immigrants in The Netherlands: do socioeconomic factors explain their adverse position? J Epidemiol Community Health 1998;52:298-304.

29. Schilder AG, Lok W, Rovers MM. International perspectives on management of acute otitis media: a qualitative review. Int J Pediatr Otorhinolaryngol 2004;68:29-36.

30. Haapkyla J, Karevold G, Kvaerner KJ, Pitkaranta A. Trends in otitis media surgery: a decrease in adenoidectomy. Int J Pediatr Otorhinolaryngol 2008;72:1207-1213.

31. Bisset F. Glue ear surgery in Scottish children 1990-1994: still plenty of ENT and public health challenges. Clin Otolaryngol Allied Sci 1997;22:233-238.

32. Mason J, Freemantle N, Browning G. Impact of effective health care bulletin on treatment of persistent glue ear in children: time series analysis. $B M J$ 2001;323:1096-1097. 
33. Singleton RJ, Holman RC, Plant Ret al. Trends in otitis media and myringtomy with tube placement among American Indian/Alaska native children and the US general population of children. Pediatr Infect Dis J 2009;28:102-107.

34. Spilsbury K, Kadhim AL, Semmens JB, Lannigan FJ. Decreasing rates of middle ear surgery in Western Australian children. Arch Otolaryngol Head Neck Surg 2006;132:1216-1220. 
SUMMARY and CONCLUSION 


\section{SUMMARY}

Otitis media is a common childhood disease and the number one reason for children to undergo surgery. In the Netherlands, there was a peak incidence in treatment with tubes during the second and fifth year of life. It was suggested that the first peak incidence in treatment, at age 16 months, could be linked to screening for hearing impairment at the age of nine months. The hearing screen was intended to detect congenital and/or early acquired sensorineural and permanent conductive hearing loss. However, most children failed the hearing screen because of persistent otitis media related hearing loss. The screen therefore functioned as a tool to detect otherwise healthy infants without obvious signs or symptoms with otitis media related hearing loss. Chronic hearing loss, independent of origin, can give speech and language problems. However, for parents it is very difficult to detect hearing loss in infants. In 2005-2006 the hearing screen at age nine months was replaced by a neonatal screen to detect chronic conductive or sensorineural hearing loss at a younger age. The disappearance of the screen at age nine months could impose a problem for infants with otitis media related hearing loss, as they might not be detected anymore. A case-finding instrument to detect and select these infants seems necessary.

In this thesis we first study the impact of the disappearance of the hearing screen at age nine months on the number of infants treated surgically for otitis media by analysing national surgical treatment data and data regarding otitis media related referral to the Ear, Nose, Throat (ENT) department for further assessment and treatment. Second, we describe how we created a case-finding instrument for those children with otitis media and otitis media related hearing loss that need further assessment.

The first study analyses the impact of the disappearance of the screening at nine months and replacement by a neonatal screen on the number of children treated surgically for otitis media. We hypothesized that the number of children treated surgically around the age of 16 months should decline after implementation of the neonatal screen. In Chapter 2 the results of this study are described. After implementation of the neonatal screen there was an increase in younger children (aged 6-11 months) being treated with tubes. However, the number of children aged 12-17 months treated with tubes did not decline but remained high. In the same period a statistically significant 
decline in the odds for undergoing adenoidectomy was observed. This crossover in predominant surgery could reflect a shift in clinical rationale towards hearing loss (treatment with tubes) rather than upper respiratory tract infections (treatment with adenoidectomy). Although treatment with tubes combined with adenoidectomy could be preferable for a child who has hearing impairment caused by otitis media, adenoidectomy is a procedure with more risks. Furthermore, there have been recent studies questioning the effect of adjuvant adenoidectomy in the treatment of children with otitis media. This may explain why specialists, when in doubt, prefer treatment with tubes only. We can only partly support the hypothesis that implementation of the neonatal screening and therefore the disappearance of the screening at nine months, would lead to fewer children being treated surgically for otitis media.

In Chapter 3 we explore referral after failing the hearing screen at nine months versus referral after general practitioner (GP) consultation because of ear and/or hearing problems. Understanding these referral pathways is particularly interesting to further analyse the hypothesis that screening for hearing loss and surgical treatment for otitis media are linked. We hypothesized that, when screening and treatment are linked, the odds for surgical treatment should be higher in those infants that failed the hearing screen at nine months and were referred compared to those infants that did not fail the hearing screen but were referred because of other ear/hearing problems. The results presented in Chapter $\mathbf{3}$ show that retrospectively, most infants treated with tubes visited their GP with ear/hearing complaints but had not failed the hearing screen (60\%). Of all infants treated with tubes, $21 \%$ had failed the hearing screen but did not visit their GP with complaints, whilst $11 \%$ had failed the screen and did visit their GP with complaints. Although most infants who were treated with tubes did not fail the hearing screen, referral after failing the hearing screen at nine months did increase the odds significantly for otitis media related referral and treatment with tubes. Infants failing the hearing screen without previous parent-initiated GP consultation because of ear/hearing problems were more often referred, and had a 2.9 higher odds $(p<0.0005)$ of tube placement than infants passing the hearing screen and with a parent-initiated GP consultation because of ear/hearing problems. Infants failing the hearing screen followed by referral and GP consultation because of ear/hearing problems had 6.1 higher odds $(\mathrm{p}<0.0005)$ 
of being treated with tubes than infants who consulted the GP because of ear/hearing problems without failing the hearing screen. General practitioners as well as ENT specialist used the outcome of the hearing screen at nine months to decide which children with ear and/or hearing problems needed further assessment and possible treatment.

As shown in Chapter 2, the number of very young children treated with ventilation tubes has increased since introducing the neonatal screen. Possibly, in the absence of the hearing screen at age nine months, GPs would more promptly refer infants to the ENT department, especially when they feel parental suspicion of otitis media related hearing loss is justified. This could then lead to earlier referral, and therefore to earlier surgical treatment of OM. We conducted a study to analyse referral after GP consultation because of ear/ hearing problems and subsequent treatment after implementation of the neonatal screen and the results are presented in Chapter 4. After implementation of the neonatal screen, the incidence of GP consultation because of ear/hearing problems increased. We also observed a shift in age. Whereas before the implementation of the neonatal screen a higher incidence at a relatively older age was observed and after implementation a higher incidence at a younger age. These findings were supported by national data: the incidence of otitis media as diagnosed by the GP in the Netherlands was higher in the second study period. These national data also showed the same shift in age, where before implementation a higher incidence at a relatively older age was observed and after implementation a higher incidence at a younger age. We also found an increase of otitis media related referral and subsequent treatment at a younger age and this led to, as most children were treated within 3 months after referral, more infants being treated at a younger age.

The results of Chapters 2, 3, 4 seem to indicate that the absence of the hearing screen at nine months leads to more clinical insecurity, and doctors are choosing to perform less hazardous surgical procedures, i.e. tubes insertion instead of adenoidectomy. The continuing high overall number of children treated with tubes, despite recent publications questioning the need for treatment of uncomplicated otitis media, does imply that there is a need for a case-finding instrument to detect and/or select those children with otitis media 
that need referral and further assessment of their hearing. This instrument should also discourage referral of uncomplicated cases and cases with transient OM to prevent unnecessary treatment and improve the accessibility for treatment of those children who will benefit from treatment.

A case-finding instrument should be inexpensive and easy to be used. To identify those children that are at risk for otitis media related hearing loss and subsequent problems we feel that risk factors for otitis media, combined in a short questionnaire, could be used as a case-finding instrument. The PEPPER questionnaire ('Persistent Ear Problems, Providing Evidence for Referral') was initially developed in the United Kingdom. This questionnaire consists of questions regarding a wide range of otitis media related factors. The PEPPER questionnaire was sent to the parents of a large group of healthy infants, who received the routine hearing screen invitation at age nine months. The data was then analysed and the results are described in Chapter 5. Univariate analysis of all items from the PEPPER questionnaire, using referral after failing the distraction hearing screen at age nine months as outcome, gave five highly significant items $(\mathrm{p}<0.01)$. The five items that were associated with increased odds of referral are 'having severe cold symptoms', 'attending day care with >4 children', 'having siblings', 'severe nasal congestion' and 'male gender'. These five items are also consistent with the reviewed literature.

There were too few children treated with tubes who failed the hearing screen and did not visit the GP with ear/hearing problems. Therefore we could not use the outcome 'failing the hearing screen and subsequent referral' (i.e. otitis media related hearing loss) for the multivariate analysis and instead used the outcome 'treatment with tubes', regardless of referral (i.e. otitis media treatment). In Chapter 6 the results of the multivariate analysis that resulted in the development of a model and resulting scoring sheet, i.e. the case-finding instrument, are described. The resulting scoring sheet consists of 10 risk factor items for otitis media. The accompanying ROC curve has an area of 0.801 indicating that this is a reasonably good instrument predicting which children are receiving tube treatment.

The next step could be a prospective evaluation in selected GP practices or Youth Health care, combined with an outcome study of treatment at the ENT department, to further study the possibility of using this scoring sheet as case- 
finding instrument to select children with otitis media related hearing loss that might benefit from referral to ENT.

\section{CONCLUSION}

Screening for hearing loss in young children has an effect on the number of children treated surgically for otitis media. Repeatedly failing the hearing screen at age nine months increases the odds of surgical treatment with tubes. After the implementation of the neonatal screen and the disappearance of the screen at nine months, the number of children treated with tubes remained high although the number of children treated with adenoidectomy decreased. A causal relationship could however not be proven. The high number of children treated with tubes does not concur with recent publications questioning the need for treatment of uncomplicated otitis media. A casefinding instrument to detect and/or select those children with otitis media that need referral and further assessment because of their hearing, while at the same time discouraging referral of uncomplicated cases and cases with transient otitis media seems necessary. This thesis presents the results of the first steps in creating a case-finding instrument for the subgroup of children with otitis media that need referral and further assessment. A risk factor model for predicting tube insertion was used to develop a scoring sheet, e.g. to be used in combination with physical examinations and tympanometry. The resulting scoring sheet looks promising, although its validity and the practical problems of routine implementation remain to be evaluated. 


\section{SAMENVATTING en CONCLUSIE}




\section{SAMENVATTING}

Otitis media is een veel voorkomende kinderziekte en de meest voorkomende reden voor een chirurgische behandeling van een kind. In Nederland werd een piek geobserveerd in de incidentie van de behandeling met trommelvlies buisjes in het tweede en vijfde levensjaar. Er werd gesuggereerd dat de eerste van deze twee pieken in behandeling, de piek op de leeftijd van 16 maanden, een relatie zou hebben met de screening voor slechthorendheid op de leeftijd van negen maanden. De gehoorscreening vond plaats om aangeboren of vroeg ontstane perceptieve en permanent conductieve slechthorendheid te ontdekken. De meeste kinderen die voor deze gehoorscreening zakten hadden echter persisterende otitis media gerelateerde slechthorendheid. De screen functioneerde derhalve als een instrument waarmee kinderen werden ontdekt die verder gezond waren en die geen duidelijke symptomen of klachten van de otitis media gerelateerde slechthorendheid hadden. Chronische slechthorendheid, ongeachte de oorzaak, kan leiden tot taal en spraak problemen. Het is echter zeer moeilijk voor ouders om slechthorendheid bij hun kinderen te ontdekken. In 20052006 werd de gehoorscreening op de leeftijd van negen maanden vervangen door een screening in de neonatale periode (de eerste 4 weken na de geboorte). Hierdoor kan chronische geleiding slechthorendheid of perceptieve slechthorendheid op een jongere leeftijd worden ontdekt. Het verdwijnen van de gehoorscreening op de leeftijd van negen maanden kan een probleem zijn voor kinderen met otitis media gerelateerde slechthorendheid, aangezien deze kinderen nu onopgemerkt kunnen blijven. Een case-finding instrument lijkt nodig om deze kinderen te detecteren en te selecteren.

In dit proefschrift wordt eerst onderzocht wat de impact is van het verdwijnen van de gehoorscreening op de leeftijd van negen maanden op het aantal kinderen dat chirurgisch behandeling ondergaat voor otitis media. Dit wordt gedaan door analyse van nationale gegevens betreffende het aantal kinderen dat deze chirurgische behandeling ondergaat en door analyse van gegevens betreffende otitis media gerelateerde verwijzing naar de Keel, Neus, Oor (KNO) afdeling voor verder onderzoek en eventueel behandeling. Vervolgens wordt beschreven hoe een case-finding instrument wordt ontwikkeld voor kinderen met otitis media en otitis media gerelateerde slechthorendheid die voor verder onderzoek in aanmerking komen. 
De eerste studie onderzoekt de invloed van het vervangen van de screening op negen maanden door de neonatale screening op het aantal kinderen dat chirurgisch wordt behandeld voor otitis media. Onze hypothese is dat het aantal kinderen dat chirurgische behandeling ondergaat voor otitis media rond de leeftijd van 16 maanden afneemt na de invoering van de neonatale screening. In Hoofdstuk 2 worden de resultaten beschreven van deze studie. $\mathrm{Na}$ het invoeren van de neonatale screening vond er een toename plaats van het aantal jongere kinderen (6-11 maanden) die behandeld werden met trommelvliesbuisjes. Echter, het aantal kinderen dat tussen de 12 en 17 maanden oud was en behandeld werd met buisjes nam niet af maar bleef hoog. In dezelfde periode vond er een statistisch significante daling plaats van het aantal kinderen waarbij de neusamandel (adenotomie) werd verwijderd. Deze verschuiving in type operatie zou kunnen weergeven dat er een verandering in het klinische denken over het belang van gehoor (waarvoor behandeling met buisjes) ten opzichte van algemene bovenste luchtweg infecties (waarvoor behandeling met adenotomie) heeft plaats gevonden. Alhoewel behandeling met trommelvliesbuisjes gecombineerd met adenotomie de voorkeur kan hebben voor kinderen met slechthorendheid ten gevolge van otitis media is een adenotomie een ingreep met meer risico's. Daarnaast zou, door recente publicaties die het nut van de adjuvante behandeling met adenotomie betwisten, het aantal kinderen dat adenotomie ondergaat afgenomen kunnen zijn. Dit kan dan verklaren dat, bij twijfel, medisch specialisten de voorkeur geven aan de behandeling met alleen trommelvliesbuisjes. Wij kunnen alleen deels de hypothese onderschrijven dat de implementatie van de neonatale screening en hierdoor het verdwijnen van de screening op negen maanden, heeft geleid tot een afname van het aantal kinderen dat chirurgisch wordt behandeld voor otitis media.

In Hoofdstuk 3 onderzoeken we verwijzing naar aanleiding van het zakken voor de gehoorscreening op de leeftijd van negen maanden versus verwijzing naar aanleiding van een huisartsenbezoek vanwege oor en/of gehoorproblemen. Het begrijpen van deze verwijzingspatronen is met name interessant om de hypothese dat screening voor slechthorendheid en chirurgische behandeling van otitis media aan elkaar gekoppeld zijn, verder te onderzoeken. Als screening en behandeling aan elkaar gekoppeld zijn, 
moet de kans dat er een chirurgische behandeling plaats vindt, hoger zijn voor die kinderen die worden doorverwezen naar aanleiding van het zakken voor de gehoorscreening op negen maanden ten opzichte van die kinderen die niet zakken voor deze screening, maar die wel verwezen worden vanwege oor/ gehoorproblemen. De resultaten die in Hoofdstuk 3 worden beschreven laten zien dat, retrospectief bekeken, de meeste kinderen die behandeld werden met buisjes behandeld werden naar aanleiding van een huisartsenbezoek in verband met oor/gehoorproblemen zonder dat zij voor de gehoorscreening gezakt waren $(60 \%)$. Van alle kinderen die behandeld werden met buisjes was $21 \%$ gezakt voor de gehoorscreening zonder dat er een huisartsenbezoek naar aanleiding van oor/gehoorproblemen had plaats gevonden terwijl $11 \%$ gezakt was voor de gehoorscreening en ook de huisarts had bezocht met klachten. Alhoewel de meeste kinderen die behandeld werden met buisjes niet waren gezakt voor de gehoorscreening, bleek dat het zakken voor deze screening op negen maanden het risico statistisch significant verhoogde voor otitis media gerelateerde verwijzing en behandeling met trommelvliesbuisjes. Kinderen die zakten voor de screening zonder dat zij naar de huisarts waren geweest in verband met oor/gehoorproblemen werden vaker verwezen en hadden een 2.9 keer hogere kans ( $\mathrm{p}<0.0005)$ op het krijgen van buisjes dan kinderen die slaagden voor de screening en wel naar de huisarts waren gegaan in verband met oor/gehoorproblemen. Kinderen die zakten voor de gehoorscreening, vervolgens werden verwezen maar ook naar de huisarts gingen met andere oor/gehoorproblemen hadden een 6.1 keer hogere kans $(\mathrm{p}<0.0005)$ op behandeling met buisjes dan kinderen die wel naar de huisarts gingen maar niet gezakt waren voor de gehoorscreening. Huisartsen en KNO artsen gebruiken de uitkomst van de gehoorscreening op de leeftijd van negen maanden om te bepalen welke kinderen met oor/gehoorproblemen verder onderzoek en eventueel behandeling nodig hebben.

Zoals in Hoofdstuk 2 staat, is het aantal jonge kinderen dat behandeld wordt met buisjes toegenomen na de introductie van de neonatale screening. Mogelijk dat huisartsen door de afwezigheid van de gehoorscreening op de leeftijd van negen maanden kinderen sneller doorverwijzen naar de KNO afdeling. Dit kan dan aanleiding geven tot een eerdere verwijzing en, daardoor, ook eerdere behandeling. We hebben daarom een studie 
uitgevoerd om verwijzing naar aanleiding van huisartsenbezoek in verband met oor/gehoorproblemen en de hierop volgende behandeling te analyseren vóór en na de implementatie van de neonatale screening. De resultaten worden beschreven in Hoofdstuk 4. Na de implementatie van de neonatale screening steeg de incidentie van huisartsenbezoek naar aanleiding van oor/gehoorproblemen. Er was ook een verschuiving te zien in leeftijd. Vóór de implementatie werd een hogere incidentie op relatief oudere leeftijd waargenomen en na implementatie een hogere incidentie op jongere leeftijd. Deze resultaten werden ondersteund door de nationale data uit huisartsenpraktijken: de incidentie van otitis media, zoals gediagnosticeerd door de huisarts in Nederland, was hoger in de tweede studie periode. Ook in deze nationale data was een vergelijkbare verschuiving te zien in leeftijd, waarbij ook vóór de implementatie een hogere incidentie op relatief oudere leeftijd werd waargenomen en na implementatie een hogere incidentie op jongere leeftijd. Verder vonden we dat ook het aantal otitis media gerelateerde verwijzingen en hier op volgende behandelingen toegenomen was op jongere leeftijd en dit leidde ertoe dat meer kinderen op jongere leeftijd behandeld werden. De meeste kinderen werden namelijk binnen 3 maanden na verwijzing behandeld.

De resultaten van Hoofdstukken 2, 3, 4 laten vermoeden dat de afwezigheid van de gehoorscreening op de leeftijd van negen maanden leidt tot meer klinische onzekerheid, en dat dokters er voor kiezen om minder risicovolle ingrepen te doen: het plaatsen van buisjes in plaats van adenotomie. Het blijvend hoge aantal kinderen dat behandeld wordt met buisjes, ondanks recente publicaties die de noodzaak van behandelen van ongecompliceerde otitis media betwijfelen, laat zien dat er een case-finding instrument nodig is. Dit instrument moet die kinderen met otitis media detecteren en selecteren die verdere verwijzing en onderzoek van hun gehoor nodig hebben. Dit instrument moet ook voorkomen dat kinderen met ongecompliceerde otitis media en kinderen met tijdelijk otitis media doorverwezen en behandeld worden, zodat de toegankelijkheid voor behandeling van die kinderen die wel nut hebben van behandeling toeneemt.

Een case-finding instrument moet goedkoop zijn en gemakkelijk in het gebruik. Wij denken dat het gebruik van risico factoren voor otitis media, 
gecombineerd in een korte vragenlijst, goed zou kunnen voldoen als casefinding instrument voor kinderen met een hoog risico op otitis media gerelateerd gehoorverlies en de hierdoor ontstaande problemen. De PEPPER vragen lijst ('Persistent Ear Problems, Providing Evidence for Referral': persisterende oor problemen, argumenten voor verwijzing) is oorspronkelijk ontwikkeld in Engeland. Deze vragenlijst bestaat uit vragen betreffende een aantal otitis media gerelateerde factoren. De PEPPER vragenlijst werd verstuurd naar ouders van een grote groep gezonde jonge kinderen, samen met de uitnodiging voor de routine gehoorscreening op de leeftijd van negen maanden. De gegevens van deze vragenlijst werden geanalyseerd en de resultaten hiervan worden beschreven in Hoofdstuk 5. Univariate analyse van alle items van de PEPPER vragenlijst met 'verwijzing na het herhaaldelijk zakken voor de gehoorscreening op de leeftijd van negen maanden' als uitkomst maat, gaf vijf zeer statistisch significante items $(\mathrm{p}<0.01)$. De vijf items die geassocieerd zijn met een verhoogd risico voor verwijzing zijn 'verkoudheidsklachten', crèche bezoek met $>4$ andere kinderen', 'het hebben van broertjes of zusjes', 'verstopte neus' en 'mannelijk geslacht'. Deze vijf items kwamen ook overeen met risico factoren gevonden in geraadpleegde literatuur.

Het aantal kinderen dat werd behandeld met buisjes en was gezakt voor de gehoorscreening, zonder dat zij de huisarts hadden bezocht met oor/ gehoorklachten was te klein om de uitkomst 'verwijzing naar aanleiding van de gehoorscreening' (otitis media gerelateerde slechthorendheid) te gebruiken voor de multivariabele analyse. In plaats daarvan hebben we voor de multivariabele analyse de uitkomst 'behandeling met buisjes' gebruikt, ongeacht de reden van de verwijzing (behandeling van otitis media). In Hoofdstuk 6 wordt beschreven hoe de resultaten van de multivariabele analyse resulteerde in een model en bijbehorend score formulier, een aanzet tot het case-finding instrument. Het ontwikkelde score formulier bestaat uit 10 risico factoren voor otitis media. De bijbehorende ROC curve heeft een oppervlak van 0.801 , wat betekent dat dit een redelijk goed instrument is om te voorspellen welke kinderen in de huidige setting behandeld worden met buisjes. 
De volgende stap zou een prospectief onderzoek zijn in geselecteerde huisartsenpraktijken of op consultatie bureaus, vergezeld van uitkomstmaten van behandeling door de KNO arts. Er kan dan onderzocht worden of dit score formulier gebruikt kan worden als case-finding instrument om die kinderen met otitis media gerelateerde slechthorendheid te selecteren die voordeel zouden kunnen hebben van verwijzing naar de KNO.

\section{CONCLUSIE}

Screenen voor gehoorverlies bij jonge kinderen heeft invloed op het aantal kinderen dat chirurgisch wordt behandeld voor otitis media. Herhaaldelijk zakken voor de gehoorscreening op de leeftijd van negen maanden verhoogt de kans op behandeling met buisjes. Na de implementatie van de neonatale screening en het verdwijnen van de screening op de leeftijd van negen maanden bleef het aantal kinderen dat werd behandeld met buisjes hoog terwijl het aantal kinderen dat behandeld werd met adenotomie afnam. Een causaal verband kon echter niet worden bewezen. Het hoge aantal kinderen dat behandeld wordt met buisjes komt niet overeen met recente publicaties die de noodzaak van behandeling van ongecompliceerde otitis media betwistten. Er is een case-finding instrument nodig dat kinderen met otitis media detecteert en selecteert die verwijzing en verder onderzoek nodig hebben vanwege slechthorendheid. Tevens kan dan de verwijzing van ongecompliceerde gevallen en kinderen met een tijdelijke otitis media worden vóórkomen. Dit promotie onderzoek beschrijft de resultaten van een eerste stap om een case-finding instrument te ontwikkelen voor die subgroep van kinderen met otitis media welke verwijzing en aanvullend onderzoek nodig hebben. Een score formulier is ontwikkeld dat op basis van een model met risico factoren voor otitis media voorspelt welke kinderen behandeld worden met buisjes. Het score formulier, welke gebruikt dient te worden samen met lichamelijk onderzoek en tympanometrie, lijkt veelbelovend maar de validiteit, de praktische toepasbaarheid en de implementatie in de praktijk moet nog onderzocht worden. 


\section{DANKWOORD}

Het onderzoek dat tot dit proefschrift heeft geleid was niet mogelijk geweest zonder het PEPPER team bestaande uit Lucien Anteunis, Mickey Chenault en Mark Haggard.

Lucien, ik weet nog goed dat ik in het eerste jaar van mijn opleiding, nu bijna 8 jaar geleden, door jou gevraagd werd om dit onderzoek te gaan doen. Tijdens de afgelopen jaren hebben we, samen met het PEPPER team, veel besproken, bedacht en geschreven. We hebben vaak op jou kamer vergaderd, waarbij er ook altijd even tijd was om bij te praten over het wel en wee in het MUMC+ en het ASz. Met jouw kennis van otitis media, opgedaan dankzij je onderzoek aan MOMES, heb je een zeer belangrijke stempel gedrukt op dit onderzoek. Je hebt altijd goede ideeën en ook goed overzicht gehad en gehouden over mijn onderzoek en dat heeft menig manuscript goed gedaan. Dankzij jouw vertrouwen in mij en ook jouw ondersteuning bij mijn onderzoek, zijn we nu aan het einde van dit promotie traject gekomen. Bedankt!

Mickey, dank voor het meedenken over mijn onderzoek en voor het doen van de statistische analyses. We hebben ons regelmatig samen gebogen over de gigantische hoeveelheid gegevens en hier samen een bruikbare dataset van gemaakt. Regelmatig zaten we samen op jouw kamer te kijken naar een van de vele SPSS files. Je optimisme en enthousiasme en, niet te vergeten, je statistische kwaliteiten hebben er aan bijgedragen dat ik mijn proefschrift heb kunnen afronden. Verder vond ik het ook altijd gezellig om je weer te zien. Bedankt voor de samenwerking in de afgelopen jaren.

Mark, your never ending enthusiasm and remarkable knowledge of everything that has to do with otitis media has been a great help in completing this thesis. Although you always seem to have more ideas to analyse and more questions to answer and therefore my research could have continued for ever. I 
do not find it surprising that you are important in otitis media research all over the world. You were, together with Mary Gannon, one of the creators of the PEPPER questionnaire. I would like to thank you for enabling the usage of this questionnaire as a basis for this thesis. Furthermore I would like to thank you for your help in completing the different manuscripts. You always replied quickly by email and therefore made it possible for me to keep up the pace.

Verder wil ik de volgende mensen bedanken voor belangrijke bijdrages aan mijn onderzoek:

Mary Gannon, you and Mark created the PEPPER item pool. Thank you! Cor Meesters, bedankt voor je medewerking aan de manuscripten. Doordat jij er wat verder van af stond, kon je met je onafhankelijke blik aangeven wat anders moest en daardoor is dit proefschrift beter geworden. Bedankt voor het samenwerken gedurende de afgelopen jaren.

Angelique Timmerman, voor het meedenken tijdens de eerste fase van mijn onderzoek.

Alle medewerkers van de Ent-administratie en dan met name Giedo Thiemann, voor het verzenden en ook ontvangen van de PEPPER vragenlijst en voor het aanleveren van de CAPAS informatie.

Alle artsen en medewerkers van de consultatie bureaus in Limburg voor hun medewerking aan mijn onderzoek. In het bijzonder de stafartsen en medewerkers van Groene Kruis Jeugdgezondheidszorg Roermond en van de MeanderGroep Zuid-Limburg te Landgraaf voor het uitvoeren van de vervolgstudie in 2010.

Frans Feron en Peter van Neer van GGD Zuid-Limburg voor hun hulp bij het verwerken van de vragenlijsten. Dankzij jullie kon ik gebruik maken van de GGD apparatuur en ik heb dus heel wat uurtjes doorgebracht bij Peter op het kantoor terwijl ik de PEPPER vragenlijsten aan het in scannen was en dit heeft mij heel veel tijdswinst opgeleverd.

De Stichting Het Heinsius-Houbolt Fonds voor het financieren van het onderzoek (de functie van Mickey Chenault en alle materiële kosten). 
Al mijn collega's op de afdeling KNO van het Maastricht UMC+ (het vroegere AZM) wil ik bedanken. Ik denk met veel plezier terug aan de jaren dat ik in het AZM werkzaam was.

Prof dr. Hans Manni en daarna Prof. dr. Bernd Kremer wil ik bedanken voor het superviseren van mijn opleiding tot KNO-arts en voor de stimulans om onderzoek te doen. De stafleden van de afdeling KNO en alle artsassistenten wil ik bedanken voor de gezelligheid en de collegialiteit tijdens mijn opleidingstijd in het AZM. Alle andere medewerkers wil ik bedanken voor de gezelligheid en voor het ondersteunen bij mijn werkzaamheden als arts-assistent en bij mijn onderzoek.

Alle medewerkers en de KNO artsen van het Catharina ziekenhuis te Eindhoven wil ik bedanken voor de gezelligheid tijdens mijn B-opleidingstijd. Frank en Nies, en later ook Maarten, bedankt voor jullie enthousiast opleiderschap. Ik denk met heel veel plezier terug aan de tijd dat ik bij jullie de routine van het KNO vak heb mogen leren. Ook wil ik alle medewerkers bedanken voor het meewerken aan mijn onderzoek. De gegevens die ik mede dankzij jullie heb kunnen verzamelen op de poli KNO hebben helaas niet geleid tot een hoofdstuk in dit proefschrift.

Inmiddels werk ik al weer bijna 4 jaar met veel plezier als lid van de maatschap KNO in het Albert Schweitzer ziekenhuis. Collega's, bedankt voor de tijd die ik van jullie heb gekregen om dit proefschrift af te ronden. Collega's en andere medewerkers van de poli KNO, bedankt voor alle gezelligheid en de goede samenwerking.

Vrienden en familie wil ik bedanken voor de invulling van mijn vrije tijd. Ik was natuurlijk niet altijd bezig met mijn onderzoek en deze momenten waren altijd een welkome afwisseling. Afspraken om bij te kletsen, thee te drinken, te borrelen, etentjes, weekendjes etc, dit alles is nodig om het vol te houden. Bedankt voor de afleiding!

Lieve pap en mam, jullie wil ik toch ook nog even apart noemen. Dankzij jullie ben ik wie ik ben en ben ik ook gekomen tot waar ik gekomen ben. Jullie vertrouwen, jullie steun, jullie aanmoedigingen hebben er voor gezorgd 
dat ik met veel vertrouwen aan mijn studie geneeskunde begon, vervolgens mijn opleiding tot $\mathrm{KNO}$ arts heb afgerond en ook nu, eindelijk, mijn promotie kan afronden. Bedankt!

Freek, lieverd, bedankt allereerst voor je geduld. Toen we elkaar leerden kennen in 2005 heb ik gezegd dat het 1ste artikel bijna klaar was. Het duurde tot 2009 totdat het ook echt klaar was en gepubliceerd kon worden. Daarna ging het allemaal iets vlotter, alhoewel de eindspurt toch nog even op zich liet wachten.

Verder ben ik superblij dat jij in mijn leven gekomen bent. Dankzij jou liefde, humor, gekkigheid, reislust en doordat jij zeilen in mijn leven hebt gebracht, zijn er gouden randjes aan mijn leven gekomen. Samen gaan we een jaar zeilen met ons zeilschip Indira. Dat lijkt mij een prachtige afsluiting van dit promotie traject. 


\section{CURRICULUM VITAE}

Willeke Lok werd geboren in Assen op 13 november 1974. Ze groeide op in Beetsterzwaag en voltooide het VWO aan het Drachtster Lyceum te Drachten in 1993. Doordat ze uitgeloot werd voor de studie geneeskunde in Nederland, startte ze haar studie geneeskunde in Brussel aan de Vrije Universiteit van Brussel in 1994. Alhoewel de eerste twee kandidaatsjaren met goed gevolg werden afgerond, besloot zij toch vanaf 1996 haar geneeskunde studie in Utrecht te vervolgen. Op 21 december 2001 ontving ze in Utrecht haar artsenbul. Na een jaar als arts-assistent niet in opleiding bij de vakgroep Chirurgie van het ziekenhuis Gelderse Vallei te Ede te hebben gewerkt, kon Willeke in april 2003 beginnen met de opleiding tot KNO arts in het Academisch Ziekenhuis te Maastricht. Tijdens de opleiding tot KNO arts werd ze door Lucien Anteunis gevraagd om onderzoek te doen naar een vragenlijst over risico factoren voor otitis media, hetgeen uiteindelijk resulteerde in dit promotie traject. Op 1 juli 2008 werd Willeke ingeschreven als KNO arts in het BIG-register en vanaf 1 augustus 2008 is zij werkzaam als KNO arts in de maatschap KNO van het Albert Schweitzer ziekenhuis.

Willeke woont samen met haar vriend Freek van Leeuwe. 


\section{LIST OF PUBLICATIONS}

1 Lok W, Anteunis LJC, Meesters C, Chenault MN, Haggard MP

Risk factors for failing the hearing screen due to otitis media in Dutch infants

Accepted for publication in Eur Arch Otolaryngol on 13-12-2011

2 Lok W, Chenault MN, Anteunis LJC, Meesters C, Haggard MP

Selecting infants with $\mathrm{OM}$ that need referral and further assessment: creating a case-finding instrument

Int J Pediatr Otorhinolaryngol 2011;75(10): 1301-7

3 Lok W, Chenault MN, Anteunis LJ.

Implementation of neonatal screening for hearing impairment: influence on pediatric otitis media surgery in The Netherlands Int J Pediatr Otorhinolaryngol. 2009;73(8):1090-4.

4 Straetmans J, Lok W, Stokroos R.

Horner's syndrome as a complication of acute otitis media B-ENT. 2006;2(4):181-4.

5 Schilder AG, Lok W, Rovers MM.

International perspectives on management of acute otitis media: a qualitative review

Int J Pediatr Otorhinolaryngol. 2004;68(1):29-36. 


\section{LIST OF ABREVIATIONS}

ALGO Automated Auditory Brainstem Response

ALSPAC

Avon Longitudinal Study of Pregnancy and Childhood

AOM

Acute Otitis Media

CAPAS

Compact Amsterdam Paedo-Audiometrical Screening

CBS

Centraal Bureau voor de Statistiek

DBC

Diagnose Behandel Combinatie

ENT

Ear, Nose, and Throat

GP

General Practitioner

MEE

Middle Ear Effusion

MEP

Middle Ear Pressure

NSDSK

Nederlandse Stichting voor het Dove en Slechthorende

Kind

$\mathrm{OM}$

Otitis Media

OME

Otitis Media with Effusion

OR

Odds Ratio

PEPPER

Persistent Ear Problems, Providing Evidence for Referral

PMEE

Persistent Middle Ear Effusion

ROC

Receiver Operating Characteristic

ROM

Recurrent Otitis Media

SES

Social Economic Status

SPSS

Statistical Package for the Social Sciences

TARGET the UK national Trial of Alternative Regimes in Glue Ear URTI Upper Respiratory Tract Infections 


\section{APPENDIX}

Appendix A PEPPER Questionnaire

Q1 Is your child healthy or has (s)he a special condition? Yes/no.

Q2 Does your child have special condition? Yes/no.

Special condition: Down syndrome, Cleft syndrome, other.

Q3 Were there special events during the pregnancy? Yes/no.

Special events: infection during pregnancy, growth retardation, early birth, other.

Q3*: 'early birth is a gestational age $<37$ weeks'. Yes/no.

Q4 Were there special events during delivery? Yes/no.

Special events: meconium stained birth water, slow start, other.

Q5: Please give your best estimate of how old your child was when (s)he first had an ear infection?

Answers: $<3$ months, 3-5 months, 6-7 months, 8-9 months, not applicable.

Q6: Please give your best estimate of how old your child was when (s)he first had a

hearing problem?

Answers: <3 months, 3-5 months, 6-7 months, 8-9 months, not applicable.

Q7: In the last three months including today, how many ear infections has your child had?

Answers: None, 1, 2, 3, >3.

Q7*: 'having had at least one ear infection in the last three months'. Yes/no.

Q8: How many of these ear infections occurred just in the last month?

Answers: None, 1, more than 1.

Q8*: 'having had at least one ear infection in the last month'. Yes/no.

Q9a: In the last three months, has your child breathed mainly through the mouth?

Q9b: In the last three months, has your child sounded as if she/he had a stuffed nose?

Q9c: In the last three months, has your child snored?

Q9d: In the last three months, has your child suffered from any of coughs, colds or sore throats?

Answers 9a-9d: never, rarely, only during a cold, often, always, not sure.

Q9a-9d*: Answer 'yes': 'often' and 'always'.

Q9a-9d*: Answer 'no': 'never, 'seldom', 'only with a cold' and 'not applicable'.

Q10: Which members of the household currently smoke in the same room as the child? Answers: none, mother, father, childminder, other.

Q10*: 'at least one smoker around the child'. Yes/no.

Q11: How many cigarettes altogether are smoked in the home each day?

Answers: none, $<20, \geq 20$.

Q12: How is the house being heated?

Answers: with central heating, with a wood burning stove, with central heating but there is also a fireplace/wood burning stove.

Q13: What sort of milk feeds did your child have during the first 6 months?

Answers: breast milk from birth until ... months of age and infant formula from ....

months, only infant formula.

Q13*: 'at least 3 months of breastfeeding'. Yes/no.

Q14: As a baby, does your child usually sleep on his/her.....?

Answers: front, side, back. 
Q15a: Would you describe your baby (up to the age of 6 months) as having a weak suck? Yes/no.

Q15b: Would you describe your baby (up to the age of 6 months) as being slow to feed? Yes/no.

Q16: Does your child attend nursery, playgroup, and childminder? Yes/no.

Q16 extra: How many children are there next to your child? .....

Q16*: 'attending day care with $>4$ children'. Yes/no.

Q17: How many children living at home (not counting this child) attend school, nursery or playgroup?

Answers: one or more older children, other child at home, but does not attend, no other child at home.

Q17*: 'having at least one sibling'. Yes/no.

Q18: This question refers to family members other than this child and only to blood relatives. Has either parent, or any brother/sister of this child, has similar ear or hearing problems?

Answers: yes, needed operation, yes, but no operation, not sure, not had a problem. Q18*: 'having at least one family member with ear of hearing problems' (father, mother or sibling). Yes/no.

Q19: Does father work: part time/full time/not applicable?

Q20: Does mother work: part time/ full time/not applicable?

Response categories of some PEPPER items were combined when category counts were extremely small, noted above with * 
Appendix B Retrospective questionnaire: Q21

Q1. How often was your child tested for hearing loss at the well-baby clinic?

Answers: 0 times (your child hasn't been tested at the well-baby clinic, but somewhere else); 1 times; 2 times; 3 times; $>3$ times

Q2. Was your child as a result of this hearing test referred by your well-baby clinic doctor to your general practitioner (GP)? Yes/No

Q3. If yes, did your GP refer your child to an ENT specialist or audiology centre? Yes/No

Q4. If yes, how long did your GP wait before referring your child as was recommended by your well-baby clinic doctor (because of the result of the hearing screen)?

Answers: Direct referral; 1 month waiting period; 2 months waiting period; 3 months waiting period; $>3$ months waiting period

Q5. Did you go to the GP with your child because of ear/hearing problems, without being referred by the health centre doctor? Yes/No

Q6. If yes, at what age for the first time?

Answers: <3 months; 3-6 months; 6-9 months; 9-12 months; 12-15 months; >15

months.

Q7. Did your GP refer your child (in the end) to a specialist? Yes/No

Q8. If yes, to which specialist (tick the box of the appropriate specialist)?

Answers: ENT specialist; Audiology centre; Paediatrician; Other doctor, being ........

Q9. Has your child been treated by an ENT doctor? Yes/No

Q10. If yes, what kind of treatment was given?

Answers:

Medication (eardrops, antibiotics)

Operation: Adenoidectomy; Grommets; Adenoidectomy and grommets;

Adenoidectomy and tonsillectomy; Adenoidectomy and tonsillectomy and grommets;

Other surgery, being

Q11. Did you have the impression that your child, if he/she underwent surgery,

benefited of the procedure? Yes/No

Q12. If yes, could you tell us what has improved?

Answers: My child's hearing has improved; My child hasn't got earaches anymore; My child doesn't snore anymore; My child hasn't got throat aches anymore; My child has more energy during the day; Other: ......... 